Energy Systems Environmental Restoration Program ORNL Environmental Restoration Program

\title{
FY 1994 Annual Summary Report of the Surveillance and Maintenance Activities for the Oak Ridge National Laboratory Environmental Restoration Program
}

Date Issued-November 1994

Prepared by

The S.M. Stoller Corporation

Oak Ridge, Tennessee

under subcontract \#70M-SC914C

Prepared for

U.S. Department of Energy

Office of Environmental Restoration and Waste Management

under budget and reporting codes EW 20 and EX 20

Environmental Restoration and Waste Management Programs

Oak Ridge National Laboratory

Oak Ridge, Tennessee 37831

managed by

MARTIN MARIETTA ENERGY SYSTEMS, INC.

for the

U.S. DEPARTMENT OF ENERGY

under contract DE-AC05-84OR21400 



\section{DISCLAIMER}

This report was prepared as an account of work sponsored by an agency of the United States Government. Neither the United States Government nor any agency thereof, nor any of their employees, make any warranty, express or implied, or assumes any legal liability or responsibility for the accuracy, completeness, or usefulness of any information, apparatus, product, or process disclosed, or represents that its use would not infringe privately owned rights. Reference herein to any specific commercial product, process, or service by trade name, trademark, manufacturer, or otherwise does not necessarily constitute or imply its endorsement, recommendation, or favoring by the United States Government or any agency thereof. The views and opinions of authors expressed herein do not necessarily state or reflect those of the United States Government or any agency thereof. 


\section{DISCLAIMER}

- Portions of this document may be illegible in electronic image products. Images are produced from the best available original document. 


\section{CONTENTS}

FIGURES $\ldots \ldots \ldots \ldots \ldots \ldots \ldots \ldots \ldots \ldots \ldots \ldots \ldots \ldots \ldots \ldots \ldots$

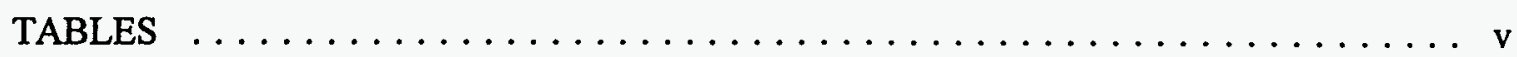

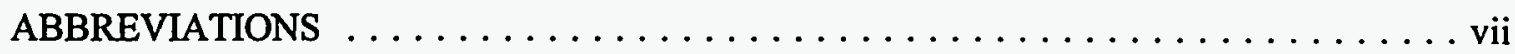

EXECUTIVE SUMMARY $\ldots \ldots \ldots \ldots \ldots \ldots \ldots \ldots \ldots \ldots \ldots \ldots \ldots \ldots$ ix

1. INTRODUCTION ............................ 1

1.1 THE SURVEILLANCE AND MAINTENANCE PROGRAM $\ldots \ldots \ldots \ldots, 1$

1.2 SURVEILLANCE AND MAINTENANCE PROGRAM OBJECTIVES $\ldots \ldots \ldots 1$

2. FY 1994 ACCOMPLISHMENTS $\ldots \ldots \ldots \ldots \ldots \ldots \ldots \ldots \ldots \ldots$

2.1 SURVEILLANCE AND MAINTENANCE PRELIMINARY INVESTIGATIONS 4

2.1.1 FY 1992 and FY 1993 Surveillance Evaluation ................ 4

2.1.2 Revised Surveillance Criteria $\ldots \ldots \ldots \ldots \ldots \ldots \ldots \ldots \ldots, 4$

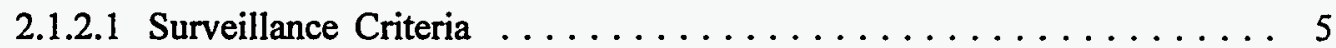

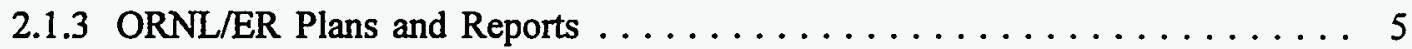

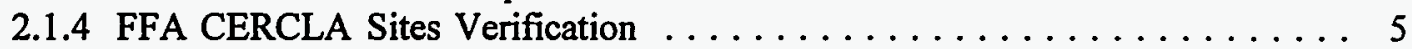

2.1.5 ORNL WAG Boundary Definition $\ldots \ldots \ldots \ldots \ldots \ldots \ldots \ldots, 8$

2.1.6 Homogenous Reactor Experiment Wells $\ldots \ldots \ldots \ldots \ldots \ldots \ldots \ldots 8$

2.1.7 Radiological Surveys .................... 8

2.1.7.1 No Further Investigation Sites $\ldots \ldots \ldots \ldots \ldots \ldots \ldots \ldots$

2.1.7.1.1 No Further Investigation Site Determinations ......... 9

2.1.7.2 Melton Valley Drive and Lagoon Road $\ldots \ldots \ldots \ldots \ldots \ldots . . \ldots$

2.1.7.3 State Highway $95 \ldots \ldots \ldots \ldots \ldots \ldots \ldots \ldots \ldots \ldots \ldots \ldots$

2.1.7.4 Tennessee Valley Authority Access Area $\ldots \ldots \ldots \ldots \ldots \ldots \ldots 11$

2.1.7.5 WAG $13(0800$ Research Area) $\ldots \ldots \ldots \ldots \ldots \ldots \ldots \ldots \ldots \ldots$

2.1.7.6 Freels Bend Sheep Barn ..................... 11

2.1.7.7 Area East of White Wing Scrap Yard $\ldots \ldots \ldots \ldots \ldots \ldots \ldots 13$

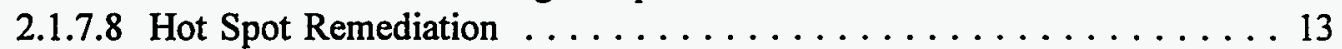

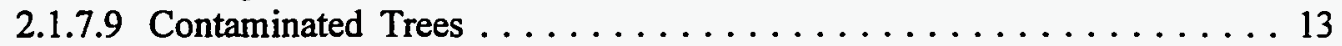

2.1.8 ER/WM Data Management $\ldots \ldots \ldots \ldots \ldots \ldots \ldots \ldots \ldots \ldots \ldots \ldots$

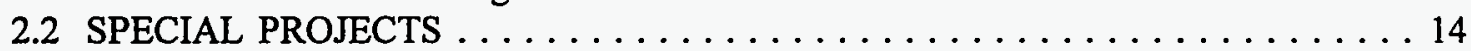

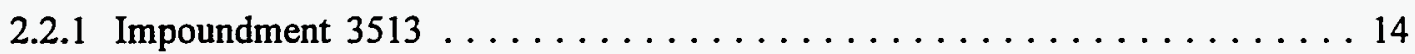

2.2.2 Solid Waste Storage Area 4 Diversion Ditch Repair . . . . . . . . . 14

2.2.3 Solid Waste Storage Area 5 Diversion Ditch Repair ............ 14

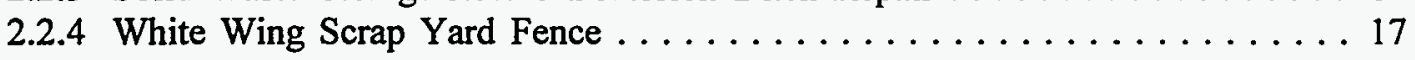

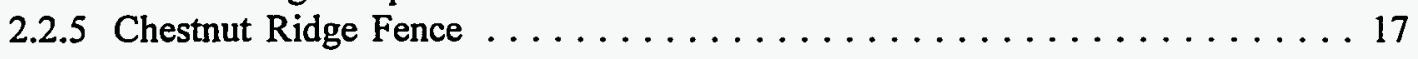




\section{CONTENTS (Continued)}

2.3 ROUTINE SURVEILLANCE AND MAINTENANCE $\ldots \ldots \ldots \ldots \ldots \ldots \ldots 17$

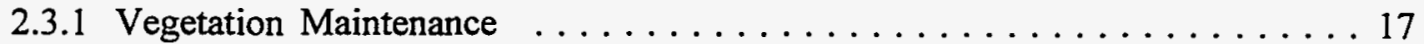

2.3 .2 RCRA Caps . . . . . . . . . . . . . . . . . . . . . 17

2.3 .3 Access Control, Safety Improvements, and Signage . . . . . . . . . 22

2.3.4 Deficiency Corrections ... . . . . . . . . . . . . . . . . . . . 22

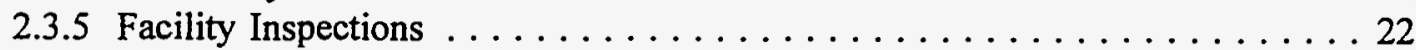

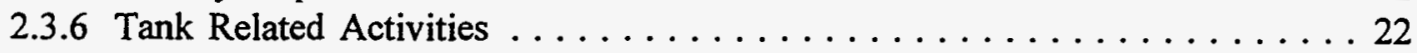

2.3 .7 Occurrence Reports . . . . . . . . . . . . . . . . . 23

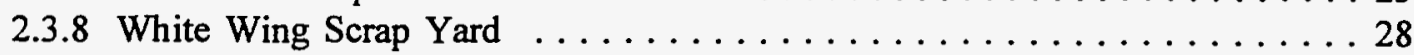

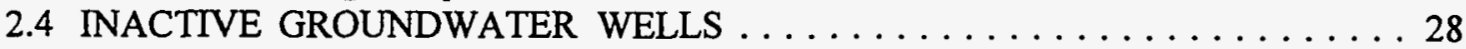

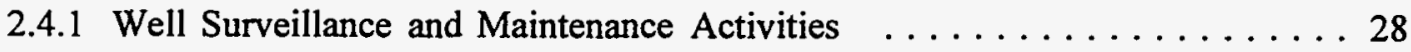

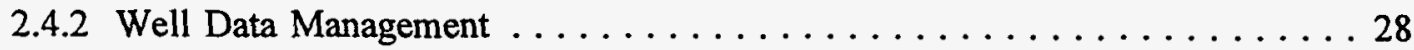

Appendix A: Evaluation of FY 1992 and FY 1993 Weekly Site/Facility Inspections . A-1

Appendix B: Sites/Facilities Managed by the ORNL ER S\&M Program $\ldots \ldots \ldots$ B-1

Appendix C: Summary of Tank Level Trending Activities $\ldots \ldots \ldots \ldots \ldots \ldots$ C-1 


\section{FIGURES}

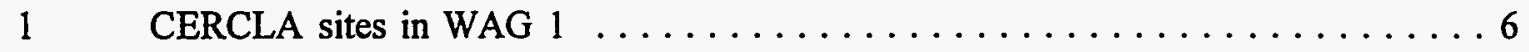

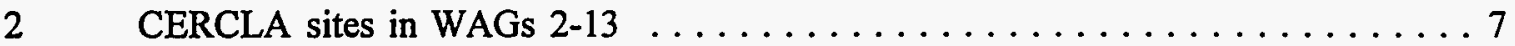

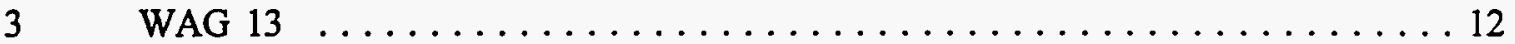

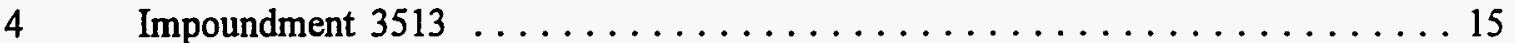

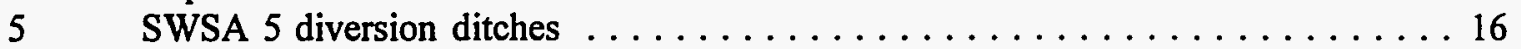

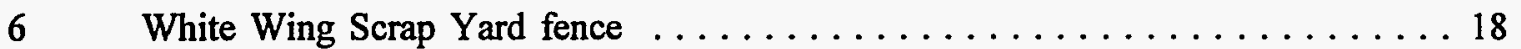

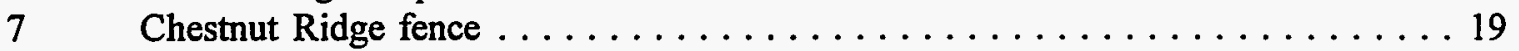

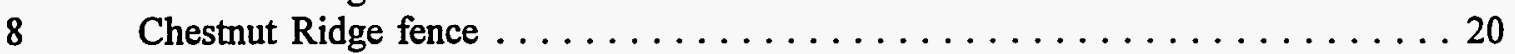

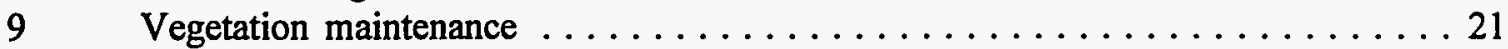

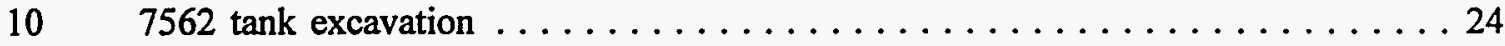

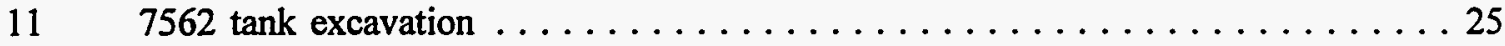

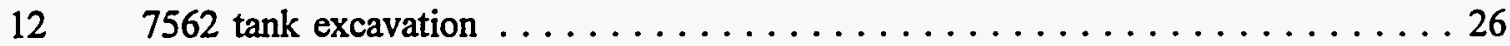

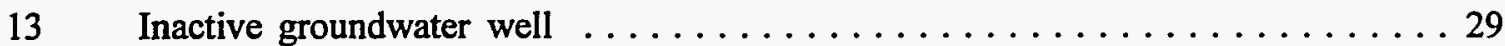

\section{TABLES}

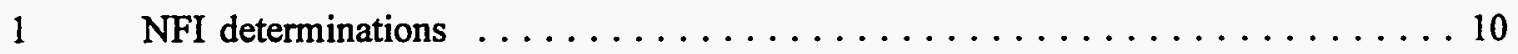

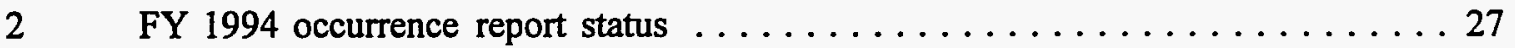




\section{ABBREVIATIONS}

$\begin{array}{ll}\text { CERCLA } & \text { Comprehensive Environmental Response, Compensation, and Liability Act } \\ \text { DOE } & \text { U.S. Department of Energy } \\ \text { ER } & \text { environmental restoration } \\ \text { ERPSD } & \text { Environmental Restoration Program Support Department } \\ \text { FFA } & \text { Federal Facilities Agreement } \\ \text { FS } & \text { feasibility study } \\ \text { FY } & \text { fiscal year } \\ \text { HRE } & \text { Homogenous Reactor Experiment } \\ \text { HSRD } & \text { Health Sciences Research Division } \\ \text { LLW } & \text { low-level waste } \\ \text { LLLW } & \text { liquid low-level waste } \\ \text { MAD } & \text { Measurement Applications and Development } \\ \text { MMES } & \text { Martin Marietta Energy Systems, Inc. } \\ \text { NaI } & \text { sodium iodide } \\ \text { NFI } & \text { no further investigation } \\ \text { ORNL } & \text { Oak Ridge National Laboratory } \\ \text { ORP } & \text { Office of Radiation Protection } \\ \text { ORR } & \text { Oak Ridge Reactor } \\ \text { R\&D } & \text { research and development } \\ \text { RCRA } & \text { Resource Conservation and Recovery Act } \\ \text { RI } & \text { remedial investigation } \\ \text { RI/FS } & \text { remedial investigation/feasibility study } \\ \text { S\&M } & \text { surveillance and maintenance } \\ \text { SWSA } & \text { solid waste storage area } \\ \text { WAG } & \text { waste area grouping } \\ \text { WM } & \text { waste management } \\ \text { WMRAD } & \text { Waste Management and Remedial Action Division } \\ \text { WWSY } & \text { White Wing Scrap Yard } \\ \end{array}$





\section{EXECUTIVE SUMMARY}

The Oak Ridge National Laboratory (ORNL) Environmental Restoration (ER) Surveillance and Maintenance (S\&M) Program was initiated to manage former waste management and environmental research sites contaminated with radioactive materials and/or hazardous chemicals. The S\&M Program is responsible for managing designated sites/facilities from the end of their operating lives until final disposition or site stabilization. Though administered by the Environmental Restoration Program Support Department (ERPSD) of ORNL's Waste Management and Remedial Action Division (WMRAD), oversight of the S\&M Program is ultimately provided by the ER Program.

To effectively manage and perform the various S\&M Program responsibilities, five summary-level work breakdown structure (WBS) elements have been established: S\&M Preliminary Investigations, Special Projects, Routine S\&M, Inactive Groundwater Wells, and Project Management.

Routine S\&M activities were conducted as scheduled throughout fiscal year (FY) 1994 at applicable inactive waste management (WM) and other contaminated areas. Overall, the ER S\&M Program maintains 47 facilities (buildings), performs vegetation maintenance on approximately 230 acres, maintains 54 inactive tanks (38 of which are owned by the ER Program), and provides overall site management on over 700 acres. In addition to the routine S\&M activities, detailed site inspections were conducted at established frequencies on appropriate sites in the ER S\&M Program. The inspections typically focused on perimeter fences, barrier chains, vegetation, diversion systems, warning signs, access roads, asphalt caps, housekeeping, and general site conditions and appearance. Because of potential vulnerabilities (safety hazards to grounds maintenance personnel and equipment, the spread of contamination, or direct radiation exposure), thorough attention was given to the solid waste storage area (SWSA) surface areas for the presence of subsided trenches. Results of these inspections were documented on checklists and the data were archived for future reference.

This document provides a summary of the FY 1994 ORNL ER S\&M Program accomplishments. 


\section{INTRODUCTION}

During fiscal year (FY) 1990, the Environmental Restoration (ER) Program was formed to research and conduct remedial actions at Oak Ridge National Laboratory's (ORNL's) contaminated areas. For the purposes of Surveillance and Maintenance (S\&M), the various Site Corrective Measures Program sites were combined with storage tanks and impoundments that were formerly supported by the Decontamination and Decommissioning Program to form the current ER S\&M Program.

The ORNL ER S\&M Program was established to manage and control areas contaminated with radioactive materials and/or hazardous chemicals. By means of the S\&M Program, applicable areas/facilities are managed from the end of their operating life until final disposition or site stabilization (whichever is deemed most appropriate based upon environmental regulations and/or best management practices). The ER S\&M Program is intended to (1) provide routine (or non-routine) S\&M of applicable sites/facilities and (2) plan for safe and orderly final closure at each site/facility.

\subsection{THE SURVEILLANCE AND MAINTENANCE PROGRAM}

The ORNL ER S\&M Program provides the essential S\&M functions at applicable sites/facilities in an attempt to ensure that they remain in acceptable condition without undue risks to human health or the environment. The inventory of sites and facilities managed by the ER S\&M Program includes a variety of former waste management (WM) areas, environmental research sites, and areas of contamination from past research and development (R\&D) operations. The majority of these facilities are inactive, however, if deemed appropriate (determined by the nature of a facility itself), the scope of the S\&M Program allows for the routine surveillance of additional facilities.

\subsection{SURVEILLANCE AND MAINTENANCE PROGRAM OBJECTIVES}

The principal objectives of the ORNL ER S\&M Program are as follows:

1. to ensure adequate containment of the residual radioactive materials remaining at the applicable sites/facilities,

2. to provide safety and security controls to minimize the potential hazards to human health and the environment, 
3. to strategically evaluate and plan final closure activities at appropriate sites/facilities, and

4. to successfully manage its facilities in a cost-effective and efficient manner.

These objectives are met through a structured program of routine S\&M actions and through the implementation of special maintenance activities when site surveillance activities indicate such a need. The scope of activities performed under the S\&M Program provides assurance that adequate site control is achieved and maintained during periods of remedial investigation (RI) and feasibility study (FS) until final site decommissioning or closure is accomplished. The S\&M Program activities are organized and conducted in the five principal areas as described below:

1. S\&M Preliminary Investigations. The scope for the S\&M Preliminary Investigations includes strategic programmatic planning, documentation, and reporting. It ensures that regulatory compliance and milestone related issues are incorporated into the development of technical, schedule, and cost baselines. All S\&M programmatic documents are written, edited, revised, published, and distributed through this element. Meeting award fee, Federal Facilities Agreement (FFA), or ER S\&M milestones, if applicable, is the responsibility of this element. It provides the scope under which preliminary radiological assessments of potentially contaminated sites are performed, and access to the solid and liquid buried waste data for the inactive and active sites. A database is currently being developed to be utilized in preliminary assessments, RI scoping projects, and risk prioritization activities.

2. Special Projects. This element supports special maintenance activities which are not routine in nature. It allows for the assessment, development, design, and implementation of Special Project scopes. It also allows for project documentation, including National Environmental Policy Act, Health and Safety Plans, and final reports (as required). These activities are non-repetitive and planning is dictated solely by site conditions. Special Projects are planned for and prioritized as far in advance as is possible. Specific actions might include limited site characterization, engineering design, contract procurement, and oversight of all field activities.

3. Routine S\&M. The scope for routine S\&M provides the field crew and support personnel to perform routine S\&M of ER Program sites until the completion of chosen remedial actions. Routine S\&M actions are necessary to ensure that ER Program sites are routinely maintained in a manner that protects human health, safety, and the environment. For such protective purposes, this element provides two distinct tasks: (1) routine site inspections, consisting of the completion of facility checksheets and logbooks, radiological and industrial hygiene surveillance, and inactive tank level monitoring, and (2) maintenance activities that are required as a result of routine site inspections or regularly scheduled maintenance. Also included is the routine maintenance of containment systems and equipment, general facility upkeep, grounds maintenance, and oversight of all field activities.

4. Inactive Groundwater Wells. This scope provides for the management of ORNL groundwater monitoring and investigatory wells that have been identified as unusable or non-essential. These activities are necessary to prevent potential contaminant migration. 
5. Project Management. The scope for Project Management includes oversight of programs, integration of prime contract and subcontract actions, and interfacing among various ER Program elements. It supports the S\&M Program elements by directing, staffing, coordinating, developing, receiving, and planning for each of the ER Program's S\&M activities. It provides program support staff for the S\&M Program activities and furnishes a means by which the roles and responsibilities of multiple Department of Energy (DOE) contractors and Martin Marietta Energy Systems, Inc. (MMES) subcontractors are integrated. Also, it provides for the assignment of administrative duties that are required for the S\&M Program's financial tracking system. 


\section{FY 1994 ACCOMPLISHMENTS}

The FY 1994 ORNL ER S\&M Program accomplishments were primarily concentrated in four of the program's five work breakdown structure (WBS) elements as defined in activity data sheet 3314 "Remedial Action Surveillance and Maintenance." These elements are (1) S\&M Preliminary Investigations, (2) Special Projects, (3) Routine S\&M, and (4) Inactive Groundwater Wells.

\subsection{SURVEILLANCE AND MAINTENANCE PRELIMINARY INVESTIGATIONS}

The primary purposes of the S\&M preliminary investigations element are to provide strategic planning, develop defensible well-documented project baselines, fulfill documentation and reporting requirements, ensure the successful completion of appropriate S\&M milestones, provide the scope under which preliminary radiological assessments of potentially contaminated sites are performed, and provide access to the solid and liquid buried waste data for the inactive and active sites.

\subsubsection{FY 1992 and FY 1993 Surveillance Evaluation}

Historically, the S\&M Program conducted its facility inspections at weekly intervals. With the original number of sites/facilities subject to routine surveillance, this meant that a total of 429 facility inspections were performed during a given quarter. It was evident that weekly inspections of an increased number of facilities would not be possible for the existing S\&M Program staff, nor could it be considered cost-effective. It was also clear, since routine site inspections are performed to avoid risk to human health and the environment, an assessment needed to be made as to the efficiency of historical surveillance activities. Accordingly, the results of weekly facility inspections performed during FY 1992 and FY 1993 were compiled, and the number of site/facility deficiencies found during those inspections were tallied (see Appendix A).

\subsubsection{Revised Surveillance Criteria}

To manage and satisfy the new requirements of the increased S\&M Program surveillances, it was determined that a value ranking must be developed and applied to all applicable facilities, new and old. This new value ranking consisted of a risk-based formula to determine the appropriate facility inspection interval. The result of this effort has been an accommodation of the increased number of facilities inspected with a minimal reduction in risk aversion. Some of the facilities, such as the deep injection wells, ponds, and pits, which had been inspected weekly did not have a level of risk to human health or the environment that justified the 
inspection interval. With the revised surveillance criteria, inspections were redistributed on the basis of risk, thus accommodating the increased number of facilities.

\subsubsection{Surveillance Criteria}

The following is a list of the newly developed risk-based surveillance criteria utilized to develop the routine site inspections for applicable facilities:

1. Risk
a. type and degree of contamination (rad/chemical, low- or high-level),
b. migration or potential migration of contaminants,
c. type of facility (above/below ground, holding pond, tank farm, etc.),
d. location of facility (relative to occupied buildings, public highways, etc.),
e. credible worst-case emergency scenario,
f. hazard analysis (based upon preliminary hazard screening or Phase 1 Safety Analysis Report Update Program, if available), and
g. effect/impact of not discovering a deficiency in a timely manner.

2. Effectiveness of surveillance

Can the critical part of the facility be inspected visually?

Are special tests required?

3. Regulatory drivers

4. Level of activity at the site/facility

Is the facility in or near a populated part of ORNL? If remote, are others routinely at the site for purposes of Remedial Investigation/Feasibility Study (RI/FS), environmental monitoring, D\&D, etc.?

5. Track record of deficiencies found in 1992 and 1993 weekly inspections.

For information pertaining to the functions and contaminants of the various inactive sites managed by the ORNL ER S\&M Program, refer to Appendix B.

\subsubsection{ORNL/ER Plans and Reports}

Plans and reports completed during FY 1994 included:

(1) the Health and Safety Plan for the Environmental Restoration Program at Oak Ridge National Laboratory (ORNL/ER-226),

(2) the Contingency Plan for ORNL ER Program Activities, and

(3) the Surface Radiological Investigations at Two Creeks Receiving Runoff from White Wing Scrap Yard, Oak Ridge Reservation, Oak Ridge, Tennessee (ORNL/ER-173).

\subsubsection{FFA CERCLA Sites Verification}

Efforts to physically locate, identify, and photograph each of the waste area grouping 


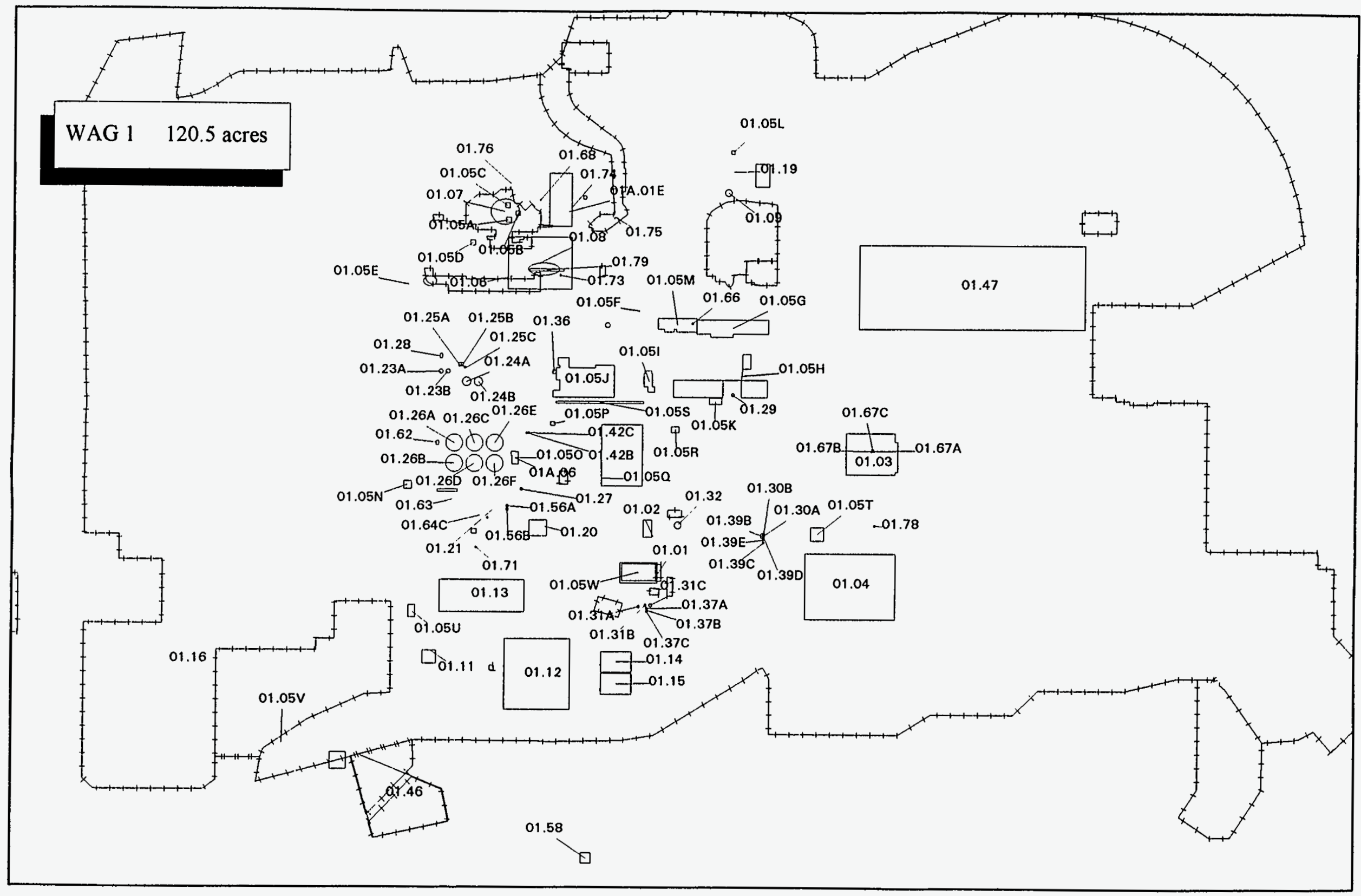

Fig. 1. CERCLA sites in WAG 1. 


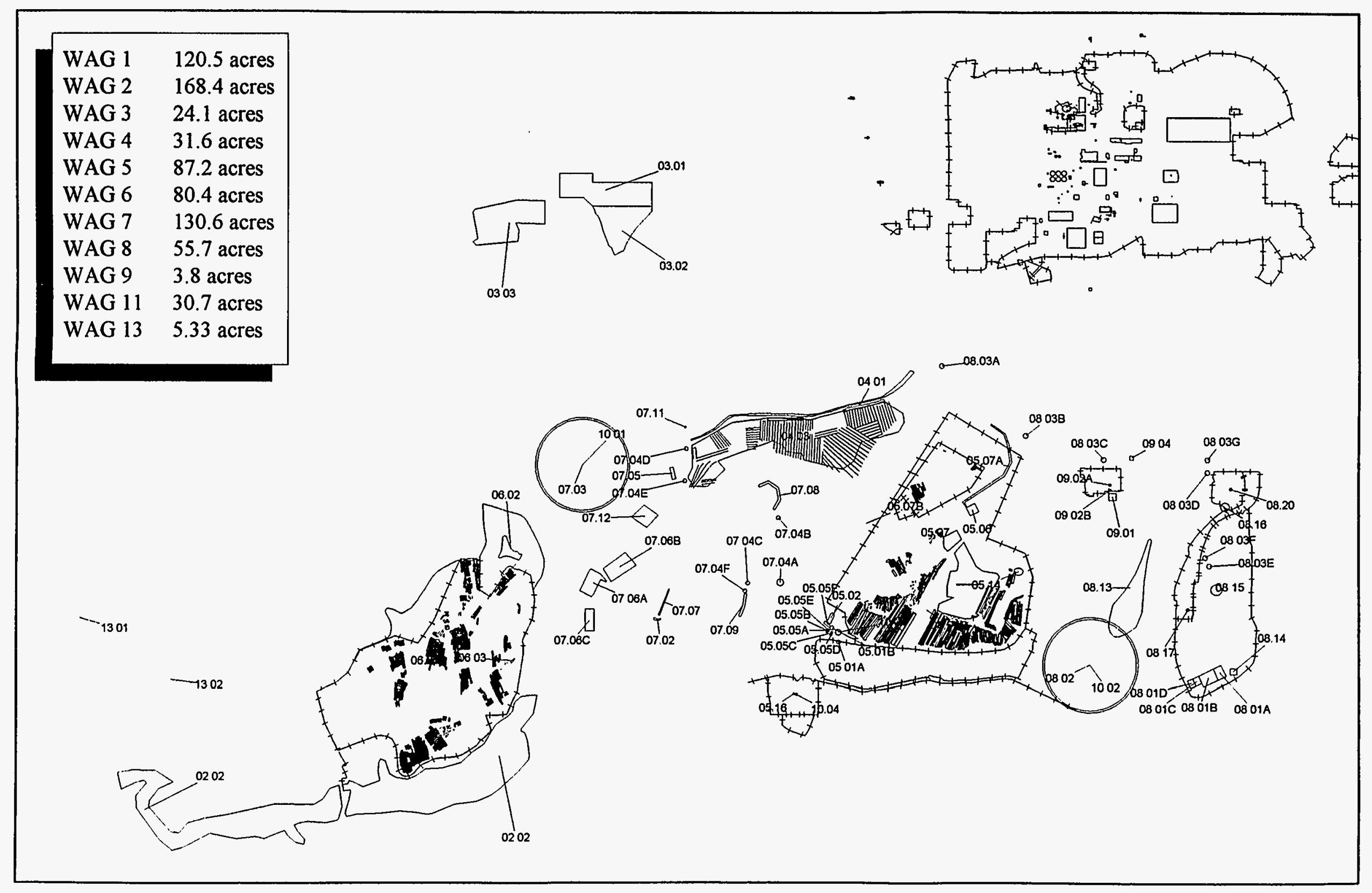

Fig. 2. CERCLA sites in WAGs 2-13. 
(WAG) 1-13 Comprehensive Environmental Response, Compensation, and Liability Act (CERCLA) sites listed in Appendix C of the FFA (see Figs. 1 and 2) were completed. Upon completion of these activities, a photo book was developed showing each of the CERCLA sites, labeled with site numbers and descriptions, and ordered by WAG. Included in this project was the update of all CERCLA-related contaminated site summary sheets.

\subsubsection{ORNL WAG Boundary Definition}

A WAG boundary document was developed to define and illustrate the approved ORNL WAG boundaries. The boundaries were established to be consistent with the FFA Appendix $\mathrm{C}$ data and the ER Program. Included in the document was a formal definition of the change control (configuration management) process accompanied by instructions for completion of the change requests, and the necessary routing requirements. Upon completion of the definition exercise, the boundaries were input and are now maintained in the Oak Ridge Environmental Information System - Geographic Information System.

\subsubsection{Homogenous Reactor Experiment Wells}

An effort to physically locate and identify the Homogenous Reactor Experiment (HRE) wells was completed. Survey and field reconnaissance reports of the spent nuclear fuel from the HRE buried in WAG 7 were completed. Two separate tours of the HRE fuel wells were conducted with representatives from the criticality safety organization and field engineering. An environmental review and documentation checklist for the work at the HRE was completed. This provided project information to the Environmental Review and Documentation Section which was necessary in the determination of relevant regulatory requirements. The resulting Project Review Summary was used to determine appropriate corrective measures.

\subsubsection{Radiological Surveys}

In FY 1994, a number of sites were surveyed by the Measurement Applications and Development (MAD) Group of ORNL's Health Sciences Research Division (HSRD). These areas and their surroundings were surveyed to determine the presence, nature, and extent of radiological contamination. Results of the surveys were used to update and better identify sitespecific conditions. This information was also used to determine the need (if any) for immediate special actions necessary to correct potential hazards to human health and/or the environment. The FY 1994 scoping survey accomplishments are described individually in the following subsections.

\subsubsection{No Further Investigation Sites}

Many of the no further investigation (NFI) candidate sites located throughout the Oak Ridge Reservation (ORR) are areas of past ecological research which employed a variety of radionuclides. Some of the radionuclides used in these experiments had short half-lives and have since decayed. It is possible, however, for longer-lived radionuclides to remain as residual material at some of the locations. There is a compelling need to determine the current baseline radiological status of these sites. As a result of this need, 22 NFI sites were surveyed for radiological contamination in FY 1994. The sites were prioritized in accordance with the anticipated level of contamination associated with each. The various site identification numbers and descriptions are as follows: 


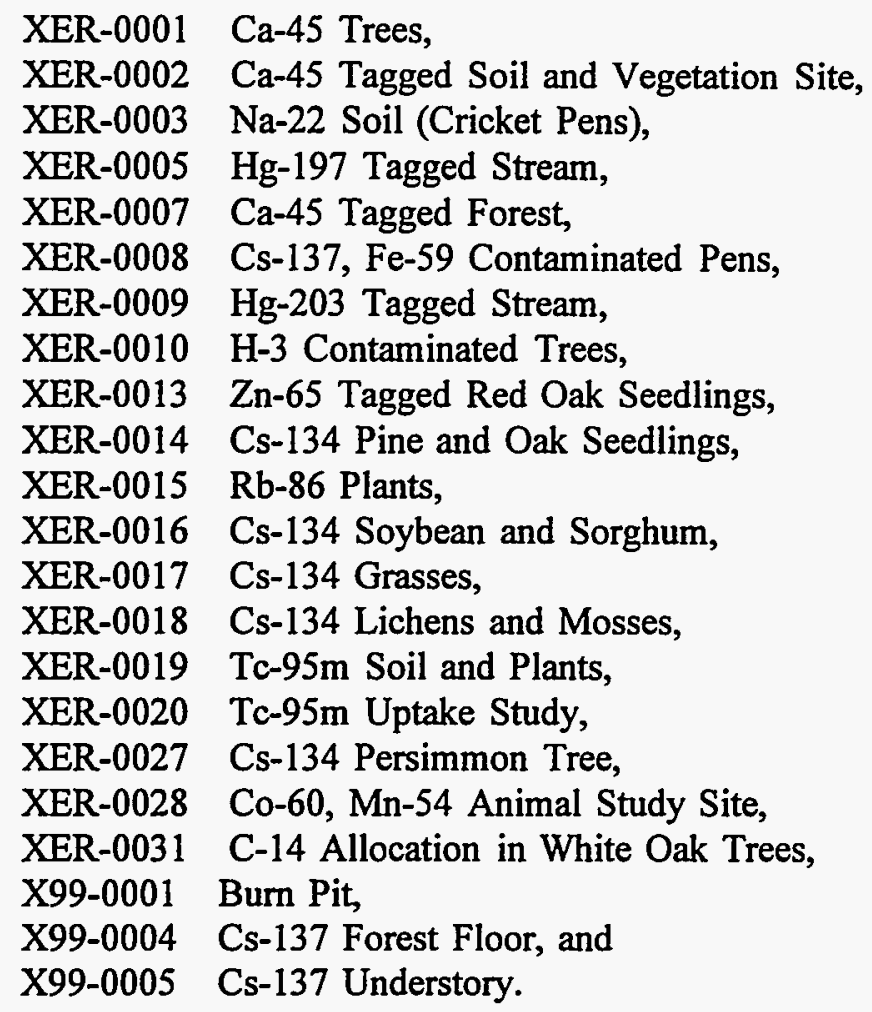

\subsection{No Further Investigation Site Determinations}

The results of FY 1994 (and previously performed) NFI site surveys have been utilized to evaluate whether a site should be included or excluded in the remedial investigation/feasibility study (RI/FS) process. The exclusion of just one site from further regulatory consideration means substantial cost savings, specifically due to costs incurred during the RI/FS process. Of the 22 sites surveyed, during FY 1994, 16 NFI determinations were made and seven of those were submitted to the regulators (see Table 1).

\subsubsection{Melton Valley Drive and Lagoon Road}

Surveys were primarily conducted along the route of underground low-level waste (LLW) lines. The surveyed areas included the road surface, roadside areas, and spot-check measurements of selected vegetation. The types of radiation measured were gamma radiation [detected with a sodium iodide ( $\mathrm{NaI}$ ) detector] and beta-gamma radiation. The total area surveyed along Melton Valley Drive is estimated to be $\sim 133,000 \mathrm{ft}^{2}$ and $\sim 216,000 \mathrm{ft}^{2}$ along Lagoon Road.

Survey Results: Various areas of soil contamination were identified. Most of these contaminated areas were at locations of known leak sites along the LLW lines. Many radioactively contaminated trees were identified. At some of these locations, the presence of "hot" trees indicated residual subsurface contamination. Several hot spots were identified along the sides of both roads and on the surface of Lagoon Road. Frequently, laboratory radionuclide analysis sampling activities remediated the anomaly. An ORNL/ER report describing the results of these surveys is currently in preparation. 
Table 1. NFI determinations

\begin{tabular}{|c|c|c|c|c|c|c|}
\hline \multirow{2}{*}{$\begin{array}{l}\text { Ord. of } \\
\text { imp. }\end{array}$} & \multirow[t]{2}{*}{ Unit id\# } & \multirow{2}{*}{$\begin{array}{l}\text { Facility } \\
\text { name }\end{array}$} & \multirow{2}{*}{$\begin{array}{l}\text { Date of } \\
\text { operation }\end{array}$} & \multicolumn{3}{|c|}{$\begin{array}{l}\text { NFI form submittal } \\
\text { (date) }\end{array}$} \\
\hline & & & & ER & Coord & Regulators \\
\hline $\mathbf{H}$ & 99.03 & Cs-137, Co-60 Contaminated Forest Area & $1969-1970$ & $4 / 25 / 94$ & $7 / 26 / 94$ & $7 / 29 / 94$ \\
\hline $\mathrm{H}$ & ER.04 & Cs-137 Bagged Leaves Study & Early 1961 & $4 / 25 / 94$ & $7 / 26 / 94$ & $7 / 29 / 94$ \\
\hline $\mathrm{H}$ & 12.01 & Closed Contractor Landfill & 1963-1975 & $4 / 25 / 94$ & $7 / 26 / 94$ & $7 / 29 / 94$ \\
\hline $\mathbf{F}$ & 16.02 & Process Waste Basin & 1962 - Never Used & $3 / 2 / 94$ & $3 / 20 / 94$ & $4 / 28 / 94$ \\
\hline F & 20.01 & Municipal Sewage Sludge Application Site & $1983-1986$ & $3 / 2 / 94$ & $3 / 20 / 94$ & $4 / 28 / 94$ \\
\hline $\mathrm{H}$ & ER.02 & Ca-45 Tagged Soil \& Vegetation & 1969 & $4 / 25 / 94$ & $7 / 26 / 94$ & $7 / 29 / 94$ \\
\hline $\mathrm{H}$ & ER.01 & Ca-45 Tagged Trees & Dec. 1969 & $4 / 25 / 94$ & $7 / 26 / 94$ & $7 / 29 / 94$ \\
\hline $\mathrm{H}$ & ER.08 & Cs-137, Fe-59 Contaminated Animal Pens & 1969 & $7 / 26 / 94$ & & \\
\hline $\mathrm{H}$ & ER.27 & Cs-134 Contaminated Persimmon Tree & June 1970 & $7 / 26 / 94$ & & \\
\hline $\mathrm{H}$ & ER.28 & Co-60 \& Mn-54 Animal Study & June 1970 & $7 / 26 / 94$ & & \\
\hline $\mathrm{H}$ & X99.04 & Cs-137 Forest Floor & April 1964 & & & \\
\hline $\mathbf{H}$ & ER.19 & TC-95m Soil and Plants & $\begin{array}{l}\text { Sept. } 1978 \\
\text { April } 1979 \\
\text { July } 1979 \\
\end{array}$ & & & \\
\hline $\mathrm{H}$ & ER.20 & TC-95m Update Studies & Feb. 1981 & & & \\
\hline $\mathbf{H}$ & $\mathrm{X} 99.01$ & Abandoned Burn Pit & 1959-1969 & & & \\
\hline $\mathbf{H}$ & ER.05 & Hg-197 Tagged Stream & Oct. 1971 & & & \\
\hline $\mathbf{H}$ & ER.07 & Ca-45 Tagged Forest & May 1966 & & & \\
\hline
\end{tabular}

$\begin{array}{ll}\mathrm{L}=\text { Low } & \mathbf{A}=\text { Active } \\ \mathbf{M}=\text { Medium } & \mathrm{F}=\text { Finished } \\ \mathrm{H}=\text { High } & \end{array}$


It should be noted that during the Lagoon Road survey (specifically from the access gate to the intersection with Highway 95), 10 soil hot spots with elevated surface beta-gamma dose rates ranging up to $24 \mathrm{mrad} / \mathrm{h}$ were identified. By taking the samples for analysis, the contamination was remediated.

\subsubsection{State Highway 95}

There were two surface surveys completed in the vicinity of state Highway 95. The first survey was conducted along the east side emergency lane from White Oak Dam to the intersection with Lagoon Road. This survey employed floor monitors for the detection of beta-gamma radiation and $\mathrm{NaI}$ scintillators for gamma radiation detection. The survey area extended from the east roadside to the edge of the woods. To date, the total area surveyed is estimated to be $\sim 80,000 \mathrm{ft}^{2}$.

Survey Results: No contamination was detected (in the survey area) along the east side of Highway 95 from White Oak Dam to the intersection with Lagoon Road.

A second survey was conducted on the east and west sides of Highway 95 north of the Lagoon Road intersection for a distance of $\sim 900 \mathrm{ft}$ on each side using gamma radiation detectors.

Survey Results: Fifteen hot spots/areas of soil contamination were identified. Sampling and subsequent radiological measurements at two hot spots determined that contamination was present in the soil. Gamma spectrometry analysis of the samples showed the presence of ${ }^{137} \mathrm{Cs}$ in concentrations of $540 \mathrm{pCi} / \mathrm{g}$ in one sample and $240 \mathrm{pCi} / \mathrm{g}$ in the other. Personnel from ORNL's Office of Radiation Protection (ORP) and ER management were immediately notified, and remedial action (soil removal) was conducted at these locations. The scoping survey results will be included in the Melton Valley Drive/Lagoon Road report.

\subsubsection{Tennessee Valley Authority Access Area}

The Tennessee Valley Authority survey area was primarily scanned for gamma radiation anomalies from Highway 95 (for a distance of $500 \mathrm{ft}$ ) and covered an area of $\sim 100,000 \mathrm{ft}^{2}$. Twenty-three hot spots and/or soil areas were identified. Elevated surface gamma exposure rates ranging up to $170 \mu \mathrm{R} / \mathrm{h}$ were found, whereas, the highest surface beta-gamma dose rate measured was $0.2 \mathrm{mrad} / \mathrm{h}$.

\subsubsection{WAG 13 (0800 Research Area)}

A cursory survey was initiated outside the fenced area (see Fig. 3) and several spots of contamination were found. However, because contractor cleanup inside the fenced area had not been completed, the MAD group was directed by ORNL ER to terminate the survey activities until further notice.

\subsubsection{Freels Bend Sheep Barn}

A radiological scoping survey was conducted to determine the barn's radiological status. At the time of the surveying activities, the barn was posted as a Regulated Area (low-level contamination). A gamma scan was performed on all accessible interior areas, and for a 


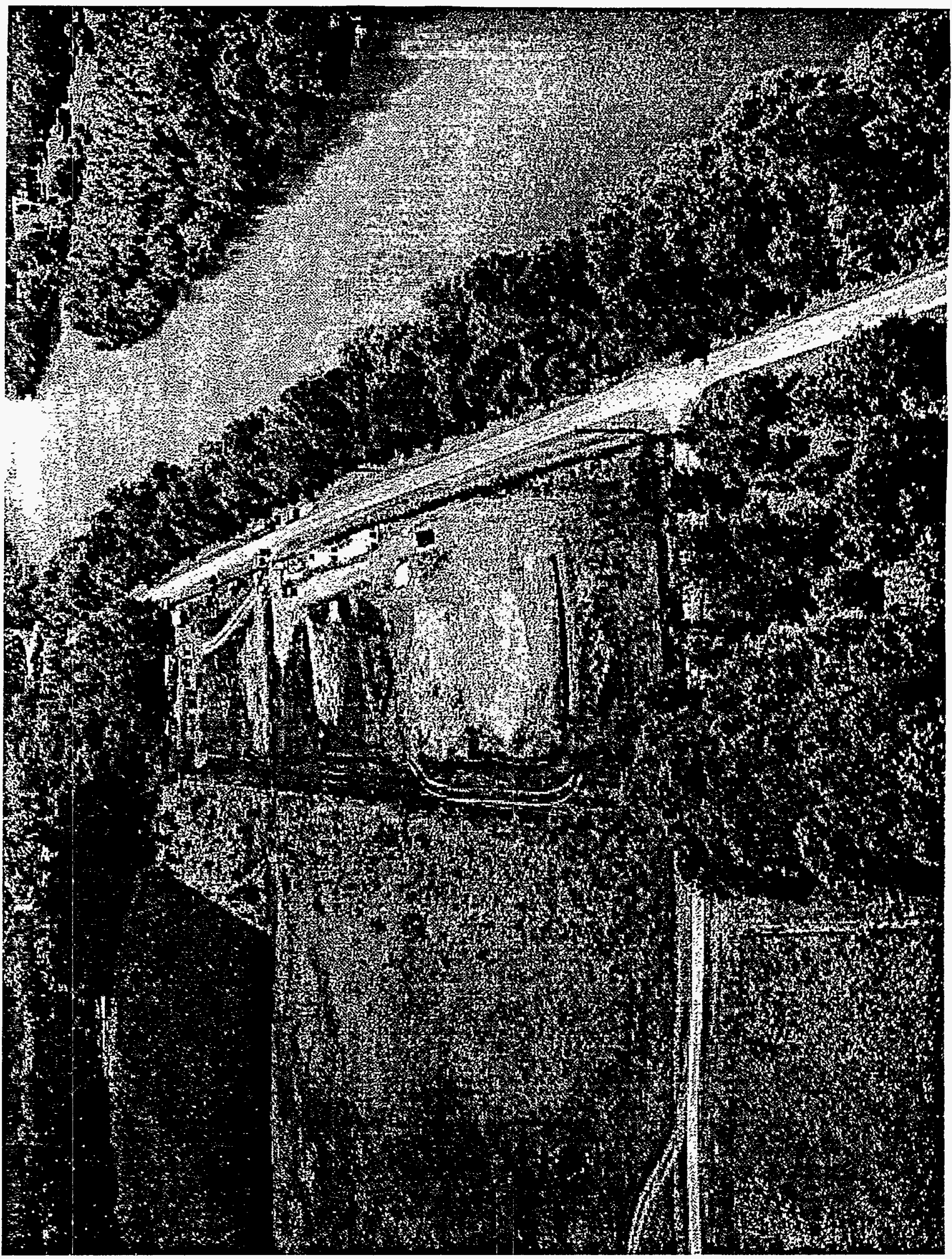


distance of approximately $20 \mathrm{ft}$ circumjacent to the exterior of the barn. A beta-gamma scan was conducted on all accessible indoor floor areas, and for a distance of about five feet beyond the exterior structure of the barn. Alpha spot-check measurements were taken on the floor at intervals of approximately seven feet. Two samples were collected outside of the barn, and seven samples were collected inside of the barn at locations where the highest gamma and betagamma radiation levels were measured.

The results of the surveying activities performed at the barn showed the only radiological anomaly to be beta-gamma radiation levels slightly greater than usual background. Based upon the findings of the survey, it was recommended that the Radiological Area Low-Level Contamination postings be removed from the site.

\subsubsection{Area East of White Wing Scrap Yard}

A cursory survey was completed including analyses of soil samples. An internal correspondence report is in preparation.

\subsubsection{Hot Spot Remediation}

During scoping surveys, sampling of contaminated media sometimes resulted in the actual cleanup of contamination. In FY 1994, it is estimated that more than 70 hot spots were remediated during sampling efforts.

\subsubsection{Contaminated Trees}

This ongoing effort includes the evaluation of human health risks and ecological consequences from radioactively contaminated trees identified near Lagoon Road and Building 7819. A team consisting of members from the ORNL HSRD's MAD and Risk Analysis Group, ORNL's Environmental Sciences Division, and ORNL's ER Program is determining the radiological status of the site and will further evaluate human health and ecological risks of the site in its current condition. In addition, evaluations will be made regarding remedial action options. To date, core samples have been extracted from four trees displaying elevated beta-

gamma radiation levels. Samples of bark and foliage have been collected from each of these trees, and a soil sample has been collected near the trees.

A radioactively contaminated tree located adjacent to the North Tank Farm was removed. The tree was packaged in a lined B-25 box and was disposed of as solid low-level waste.

\subsubsection{ER/WM Data Management}

Understanding the importance of compiling accurate data and maintaining its integrity, an effort was initiated to capture and centralize all WM Program data. During data compilation activities, document searches have been aggressively initiated and every potential information resource has been utilized, including the hosting of an ORNL "retirees" meeting which was conducted to gather historical information on stored and buried TRU wastes. These ongoing efforts will provide centralized access to the solid and liquid buried waste data associated with active and inactive sites. The resulting database(s) will have the potential to be utilized in preliminary assessments, RI scoping projects, and risk prioritization activities. 
Maplnfo and FoxPro database structures have been developed to receive the input of research data, and interact with each other. Layers containing various sites/facilities continue to be developed and enhanced within MapInfo. Solid Waste Information Management System Mod I, II, and III waste data continue to be input into appropriate FoxPro databases.

\subsection{SPECIAL PROJECTS}

In certain instances, site repairs or improvements may be necessary to correct material degradation problems, ensure radionuclide containment, or eliminate a significant safety concern. The scope of such projects can vary from routine construction projects to complex tasks requiring multi-division and subcontractor participation. This element allows for the assessment, development, design, and implementation of special projects which are not routine in nature. These projects are non-repetitive and planning is dictated by site conditions. The S\&M Program's special project accomplishments in FY 1994 are presented in the following subsections.

\subsubsection{Impoundment $\mathbf{3 5 1 3}$}

Due to the detection and confirmation of seeps, the Impoundment 3513 "Emergency Berm Repair" project was initiated. The specific actions associated with this project involved: (1) lowering the water level within the 3513 Settling Basin by transferring water to the existing Process Waste System and treating it at the existing Process Waste Treatment Plant, (2) mixing approximately $5000 \mathrm{lb}$ of bentonite with locally available clay-soil (approximately three parts native clay-soil to one part bentonite), (3) clearing the existing vegetation on the interior surface of the south berm of the Settling Basin, (4) placing the bentonite/clay-soil mixture on the interior surface of the south berm of the settling basin, and (5) grading and compacting the bentonite/clay-soil mixture. Upon completion, the bentonite/clay-soil mixture formed an approximately 6-in-thick $\times 4$-ft-wide $\times 220$-ft-long blanket covering the entire length of the interior surface of the south berm of the Settling Basin (see Fig. 4).

Additional activities performed at Impoundment 3513 consisted of tracer studies, dye testing, sampling campaigns, the initiation and completion of two occurrence reports, and the replacement of goose control wires which had been removed for sampling activities.

\subsubsection{Solid Waste Storage Area 4 Diversion Ditch Repair}

Though many of the activities were primarily completed in FY 1993, the solid waste storage area (SWSA) 4 diversion ditch project, which repaired the diversion ditch installed on the north side of Lagoon Road to divert runoff from Haw Ridge around SWSA 4 rather than through it, was officially completed in FY 1994.

\subsubsection{Solid Waste Storage Area 5 Diversion Ditch Repair}

In FY 1993, Energy Systems Engineering determined that the SWSA 5 diversion ditches (see Fig. 5) did not serve their intended purpose (surface water control), and that the best course of action would be to break up the ditches and cover the areas with soil and vegetation. Accordingly, in FY 1994, the ditches were demolished, the area was backfilled with clean soil, seeded for grass, and straw was placed over the top. 


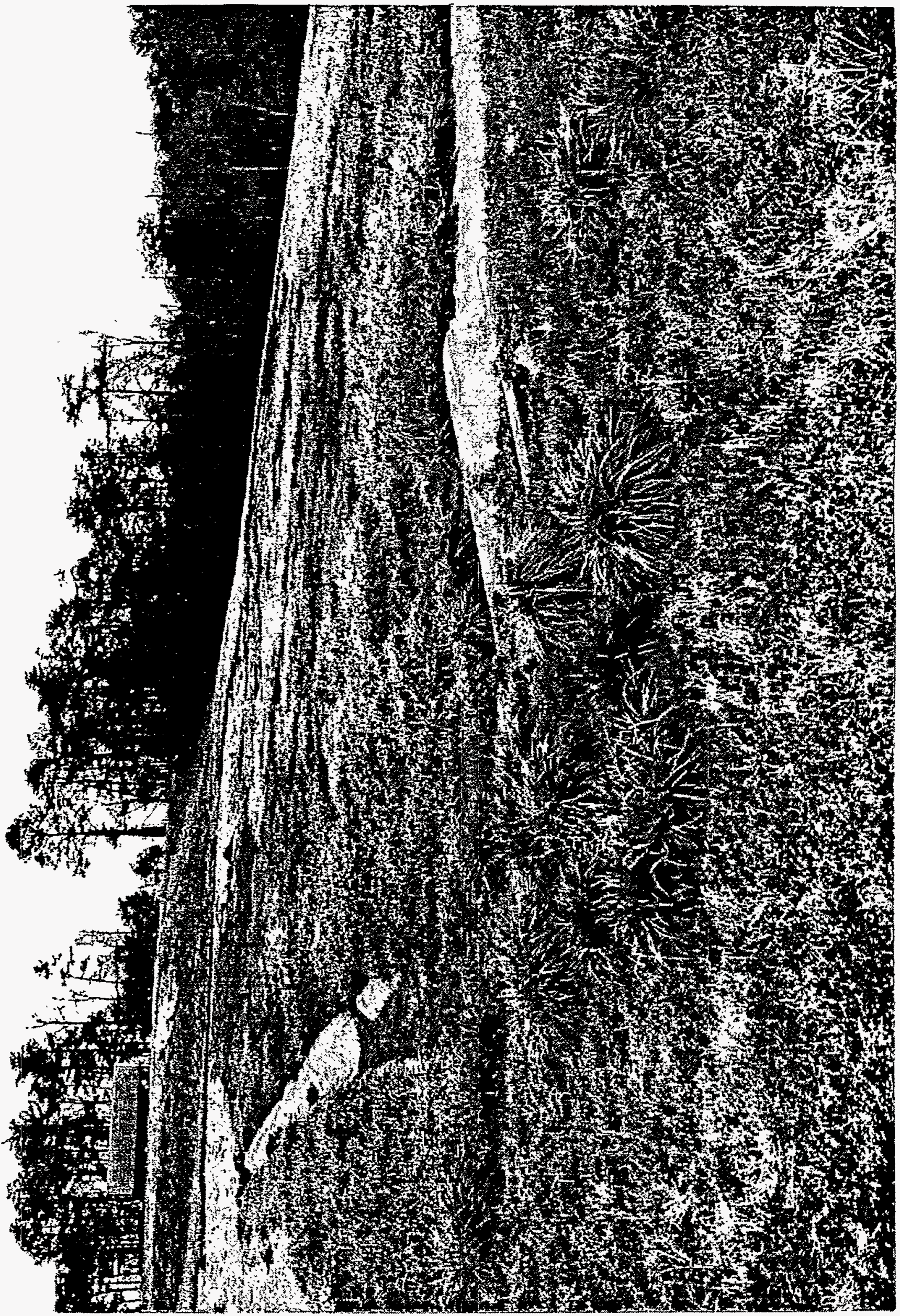




\subsubsection{White Wing Scrap Yard Fence}

Though many of the activities were primarily completed in FY 1993, the White Wing Scrap Yard (WWSY) fencing project (see Fig. 6), which was designed/intended to provide access control to approximately 35 acres within the WWSY, was officially completed in FY 1994. Project closure/completion activities consisted of the installation of gates and the placement of signs.

\subsubsection{Chestnut Ridge Fence}

Though many of the activities were primarily completed in FY 1993, the Chestnut Ridge (see Figures 7 and 8) fencing project, designed to provide access control for the Chestnut Ridge Sites, was officially completed in FY 1994. Project closure/completion activities consisted of the installation of gates and the placement of signs.

\subsection{ROUTINE SURVEULANCE AND MAINTENANCE}

Routine S\&M activities were conducted as scheduled throughout FY 1994 at applicable inactive WM and other contaminated areas. Overall, the ER S\&M Program maintains 47 facilities (buildings), performs vegetation maintenance on approximately 230 acres, maintains 54 inactive tanks (38 of which are owned by the ER Program), and provides overall site management on over 700 acres. In addition to the routine S\&M activities, detailed site inspections were conducted at established frequencies on appropriate sites in the ER S\&M Program. The inspections typically focused on perimeter fences, barrier chains, vegetation, diversion systems, warning signs, access roads, asphalt caps, housekeeping, and general site conditions and appearance. Because of potential vulnerabilities (safety hazards to grounds maintenance personnel and equipment, the spread of contamination, or direct radiation exposure), thorough attention was given to the SWSA surface areas for the presence of subsided trenches. Results of these inspections were documented on checklists and the data were archived for future reference.

\subsubsection{Vegetation Maintenance}

Vegetation maintenance includes a variety of activities from mowing grass (see Fig. 9) to trimming or removing vegetation and downed trees, and is continuously required for a variety of purposes. Such purposes might include upgrading the appearance of a site or facility, permitting access for surveying activities, and enhancing inspection processes. During FY 1994, vegetation maintenance was routinely performed at numerous areas, including the White Oak Creek Sediment Retention Embayment, various SWSAs, ponds, tank farms, fence lines, deer fences, trenches, pits, and the hydrofracture facilities.

\subsubsection{RCRA Caps}

The routine Resource Conservation and Recovery Act (RCRA) Cap inspections and repairs were performed as scheduled by internal MMES personnel and off-site contractors (S\&ME and Geotek). The inspections consisted of the following activities:

Inspection of all high-density polyethylene panels, 


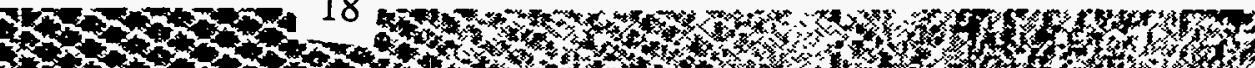

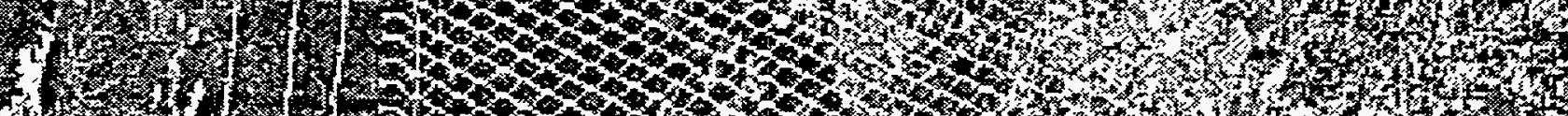

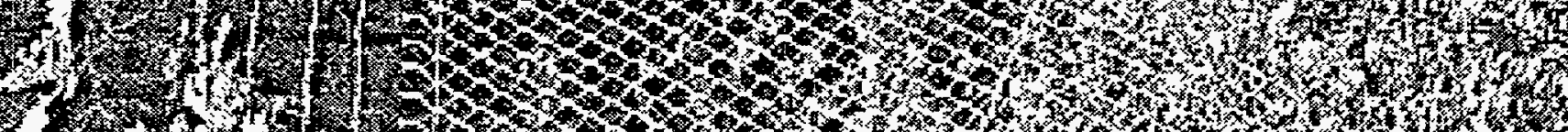

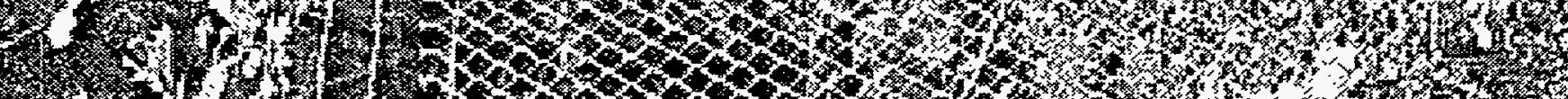

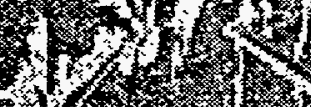

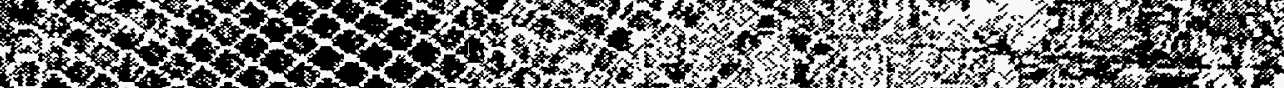

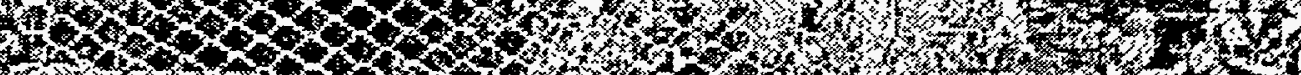

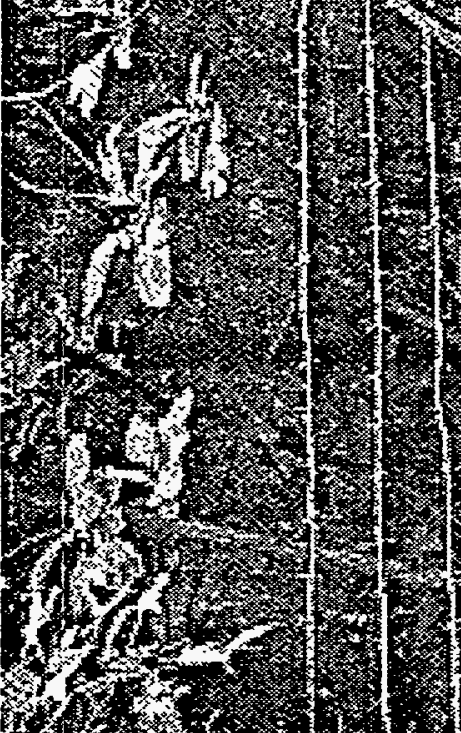

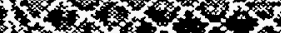

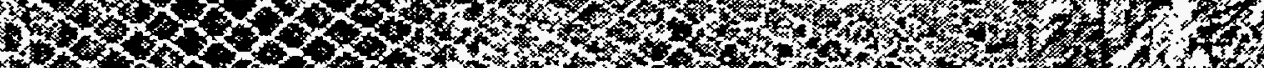

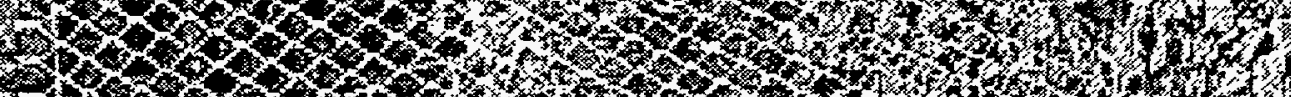

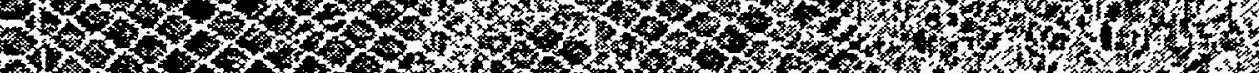

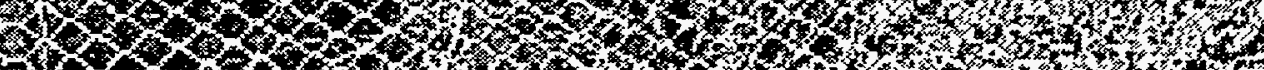

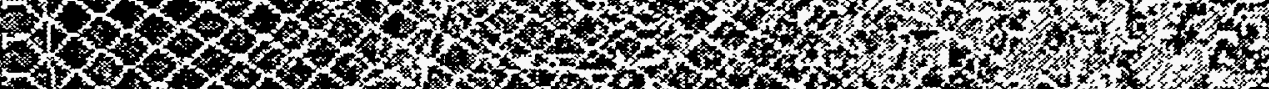

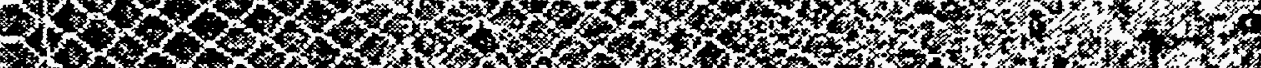

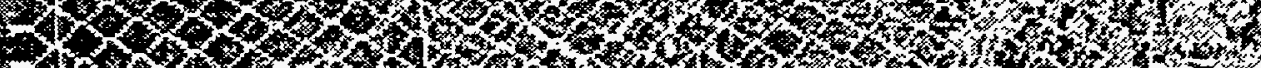

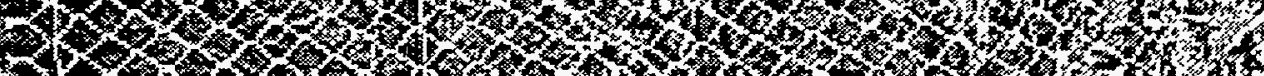

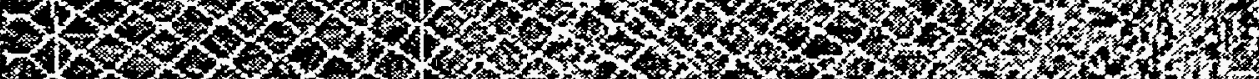

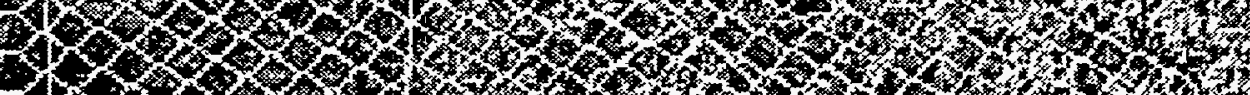

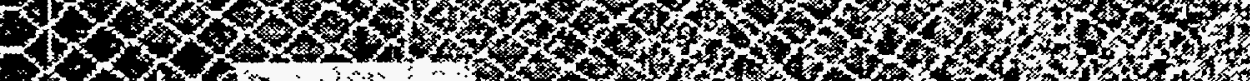

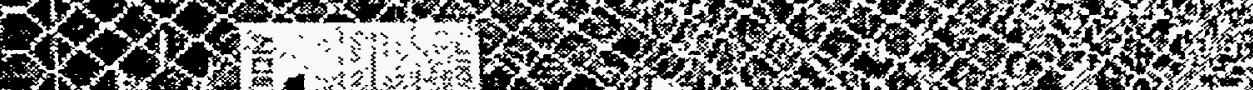

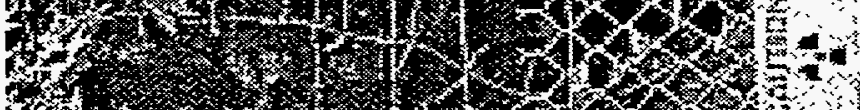

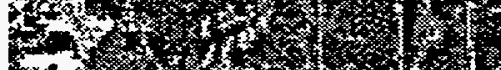

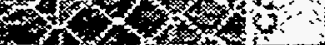

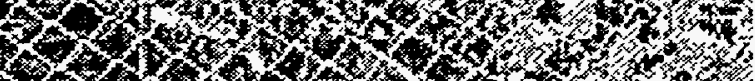

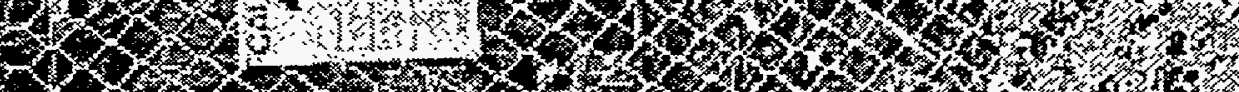

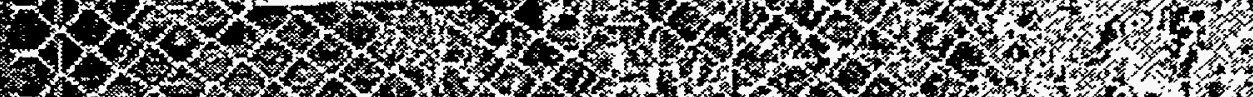

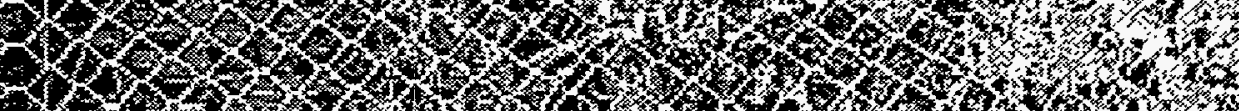

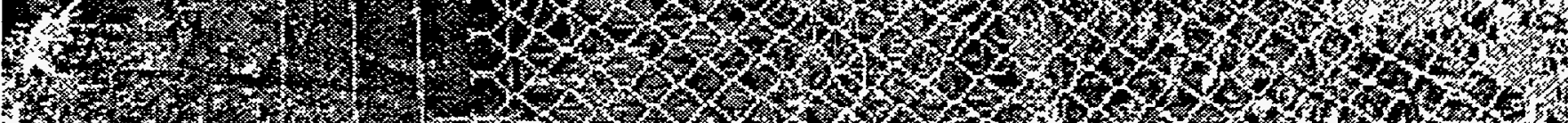

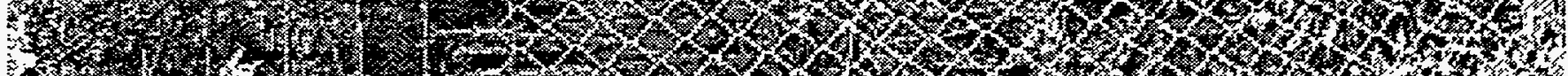
For

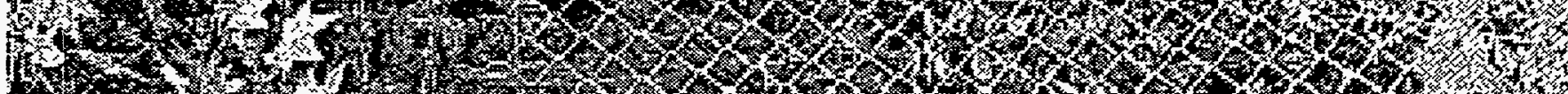
3
1

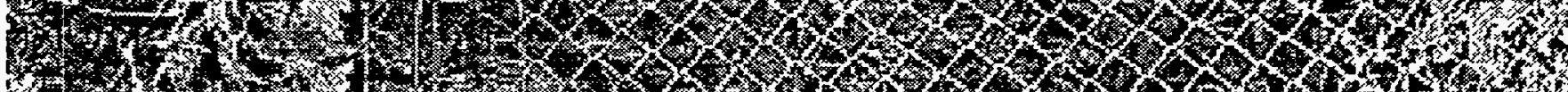

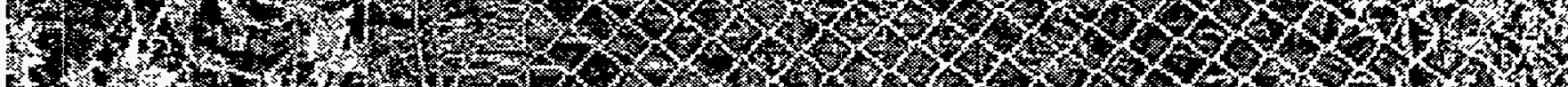

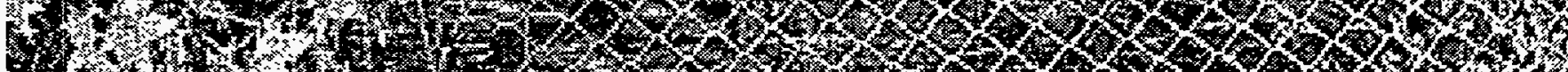

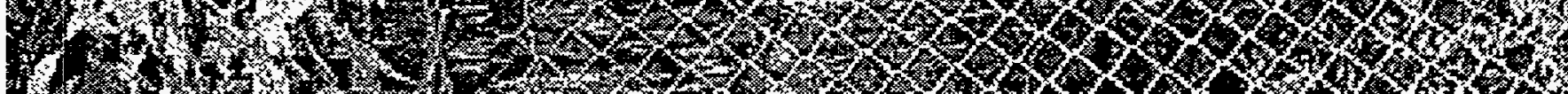

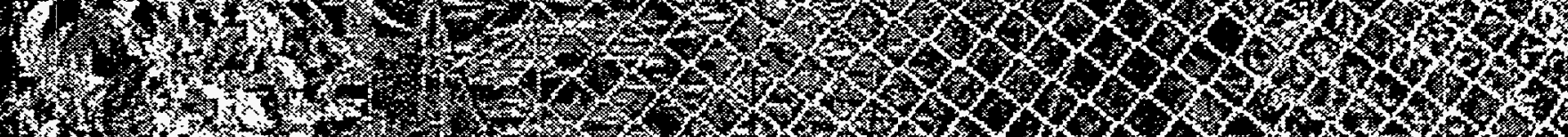

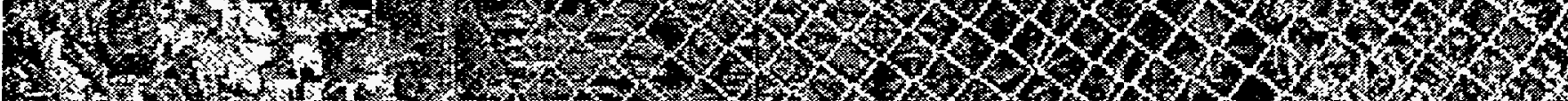

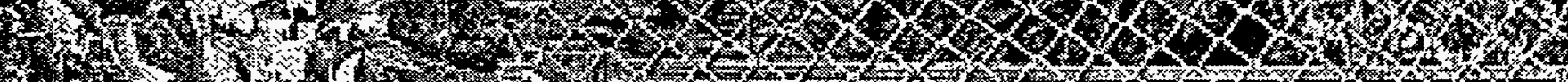

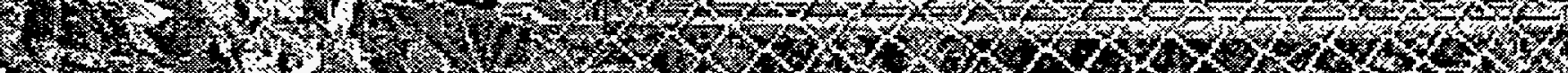

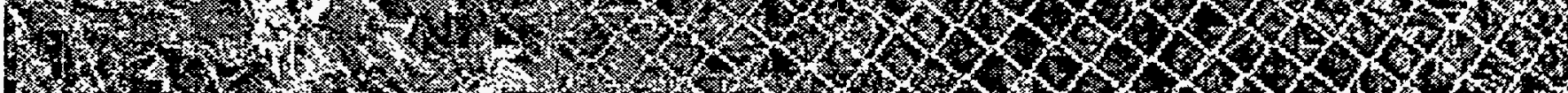

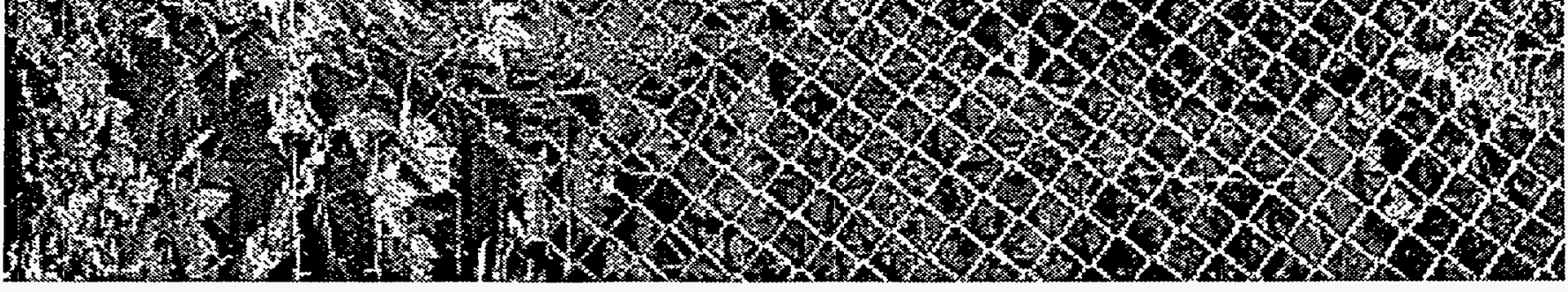




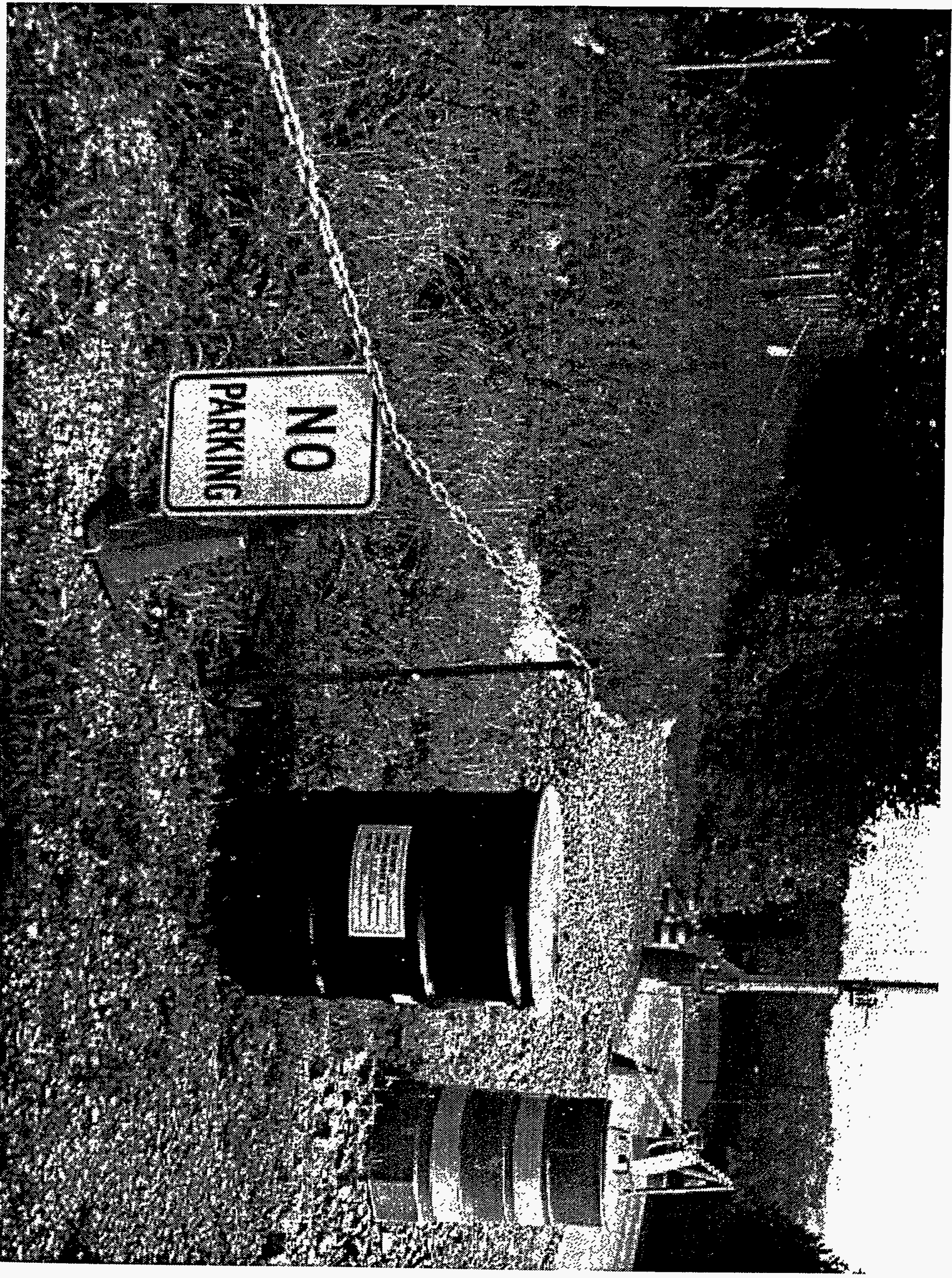




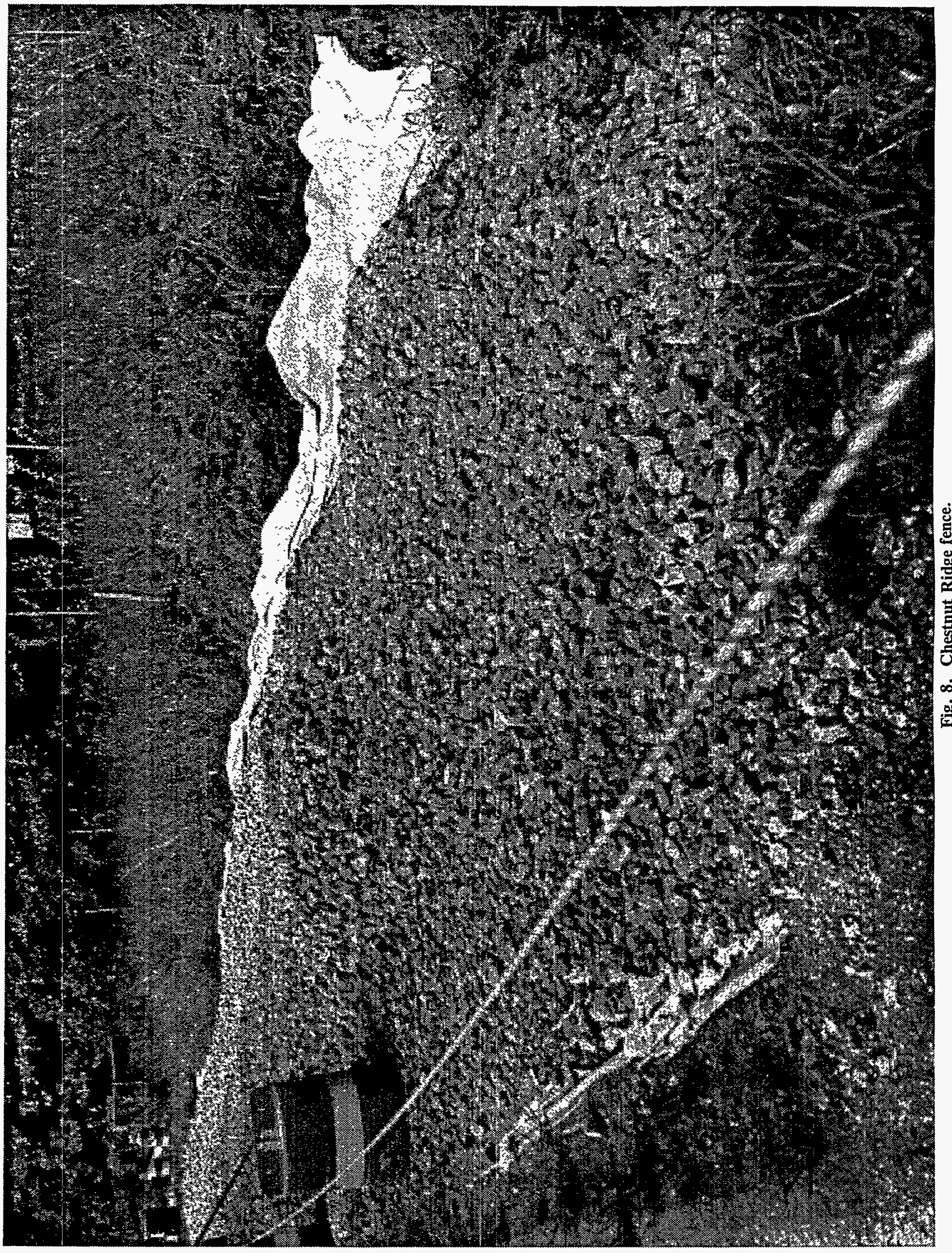




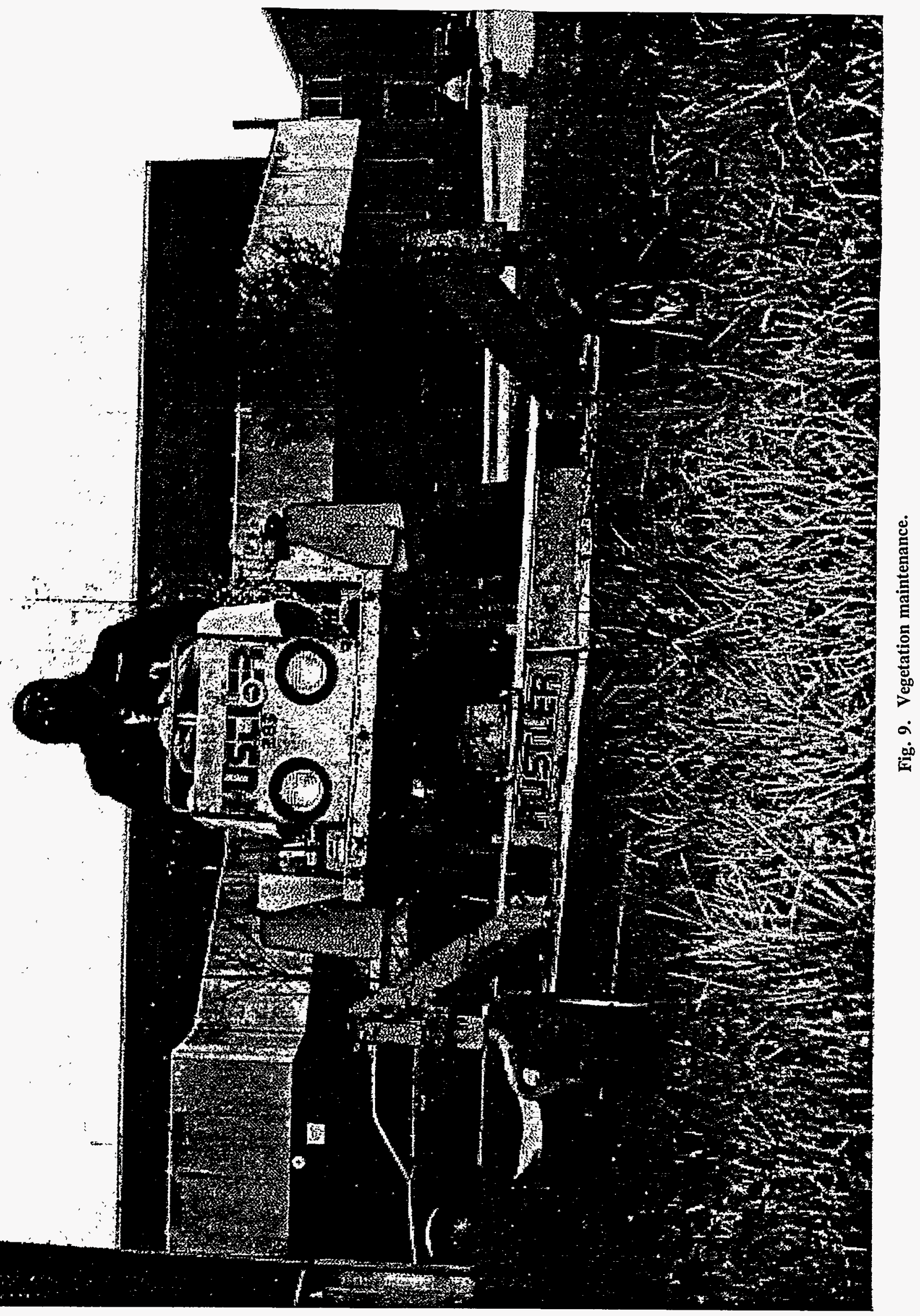


Collection of the "sacrificial" liner samples, Inspection of panel seams,

Inspection of all penetrations to ensure cap integrity,

Inspection of all anchor trenches and pillows, and

Laboratory testing of three $2 \mathrm{ft} \times 4 \mathrm{ft}$ sacrificial samples.

Geotek repaired all noted deficiencies of the RCRA Caps. Additional activities performed in association with the RCRA caps were (1) the review and approval of a RCRA Caps Training Lesson Plan according to WMRA-RA302-S, (2) the timely submittal of appropriate documentation to Environmental Compliance, (3) the submittal of check sheets and weekly site inspection sheets to the document management center for the purpose of archiving the information, and (4) a corporate audit of the RCRA Closure Plan.

\subsubsection{Access Control, Safety Improvements, and Signage}

A number of access control, safety improvements, and signage projects were initiated and completed during FY 1994. Roads near the Old Hydrofracture Facility were graveled to improve access to wells in that area. A WAG area access control self-assessment was conducted by posting a roving security inspector at all WAG entrances to determine if access requirements were being followed. A large number of WAG access, radiological, speed limit, and personnel safety signs were ordered and/or fabricated. Where necessary, walk-through gates were installed in deer fences. Jersey barriers were installed around the north-west corners of the North and South Tank Farms. Posts and chains were promptly installed around areas identified as contaminated sites.

\subsubsection{Deficiency Corrections}

Several electrical deficiencies and a leaking valve were identified in the South Tank Farm during a routine safety walk-through. These deficiencies were corrected or significantly reduced, thus returning the area to an acceptable condition.

\subsubsection{Facility Inspections}

A number of non-routine facility inspections were completed during FY 1994. Facility 3110 was inspected by DOE and ORP personnel. The purpose of the inspection was to determine the facility's compliance with ORNL Radiation Protection Procedures, DOE Radiological Manual recommendations, and the requirements of 10 CFR 835. In Building 7819, personnel from the Chemical Technology Division, quality assurance, and ORP inspected one of the shielded transfer tanks and planned appropriate decontamination measures. The purpose of this plan was to place the tank (once cleaned) in standby status for use as a transport vehicle in case transfer lines were to fail testing processes and could not be used to transfer Liquid Low-Level Waste (LLLW).

\subsubsection{Tank Related Activities}

During FY 1994, a variety of tank-related (see Figs. 10, 11, and 12) activities were performed including: 
- Monthly level trend data reports were compiled during the year. The data were collected for tanks T-1, T-2, T-3, T-4, T-9, TH-4, W-1, W-2, W-3, W-4, W-5, W-6, W-7, W-8, W-9, W-10, W-11, W-1A, WC-15, and WC-17. Tanks TH-4 and W-3 were close to full capacity throughout the year, but did not overflow. Some tank levels were very sensitive to rainfall. Tanks WC-15 and WC-17 levels were especially sensitive to rainfall and levels rose and fell with respect to groundwater levels. Tank W-1A levels were reported to the Waste Operations Control Center, the levels tripped alarms throughout the year which would lead to Waste Operations emptying some of the tank contents. Further details about the inactive LLLW tank-related activities are presented in Appendix $C$.

- Typically there were few problems with the inactive tanks. Most level trends indicated either a response to increased rainfall, or that the tanks were just filling very slowly; two of the tanks were affected by ground water table changes. The majority of serious upsets in the level data resulted from instrumentation malfunction or system outages. Afterwards, the level data would return to nearly the same level as previously indicated prior to the failure or downtime, indicating no real change in level, but rather only equipment failure.

- After a major rainfall event, Tank 7562, near the HRE Building, had an overflow episode which was categorized as a Level III Occurrence. An unknown source entered the tank. The tank, welded shut and buried, was unearthed, opened for inspection, and emptied. While the source has not yet been identified, future overflow episodes are unlikely as long as the pit does not fill.

- A State of Isolation evaluation for 54 Category D inactive storage tanks was initiated.

- A drafting of procedures for liquid removal from tanks $\mathrm{W}-1, \mathrm{~W}-2, \mathrm{~W}-3$, and $\mathrm{W}-4$ was initiated.

- A draft Engineering Service Order for the "Urethane Foam" tank removal project was completed.

- Reports for various tanks, covering the locations of incoming pipelines, capped or uncapped status, locations of other tank core openings, etc. were completed and distributed.

- Level instrumentation repairs were performed.

- The final draft of the Waste Certification Procedure for the pumping of inactive tanks was completed.

- A Readiness Review of the "Gunite and Associated Tanks Operable Unit Sampling Project" was conducted.

\subsubsection{Occurrence Reports}

One Category II and seven Category III occurrence reports were initiated and closed during FY 1994 (see Table 2). 


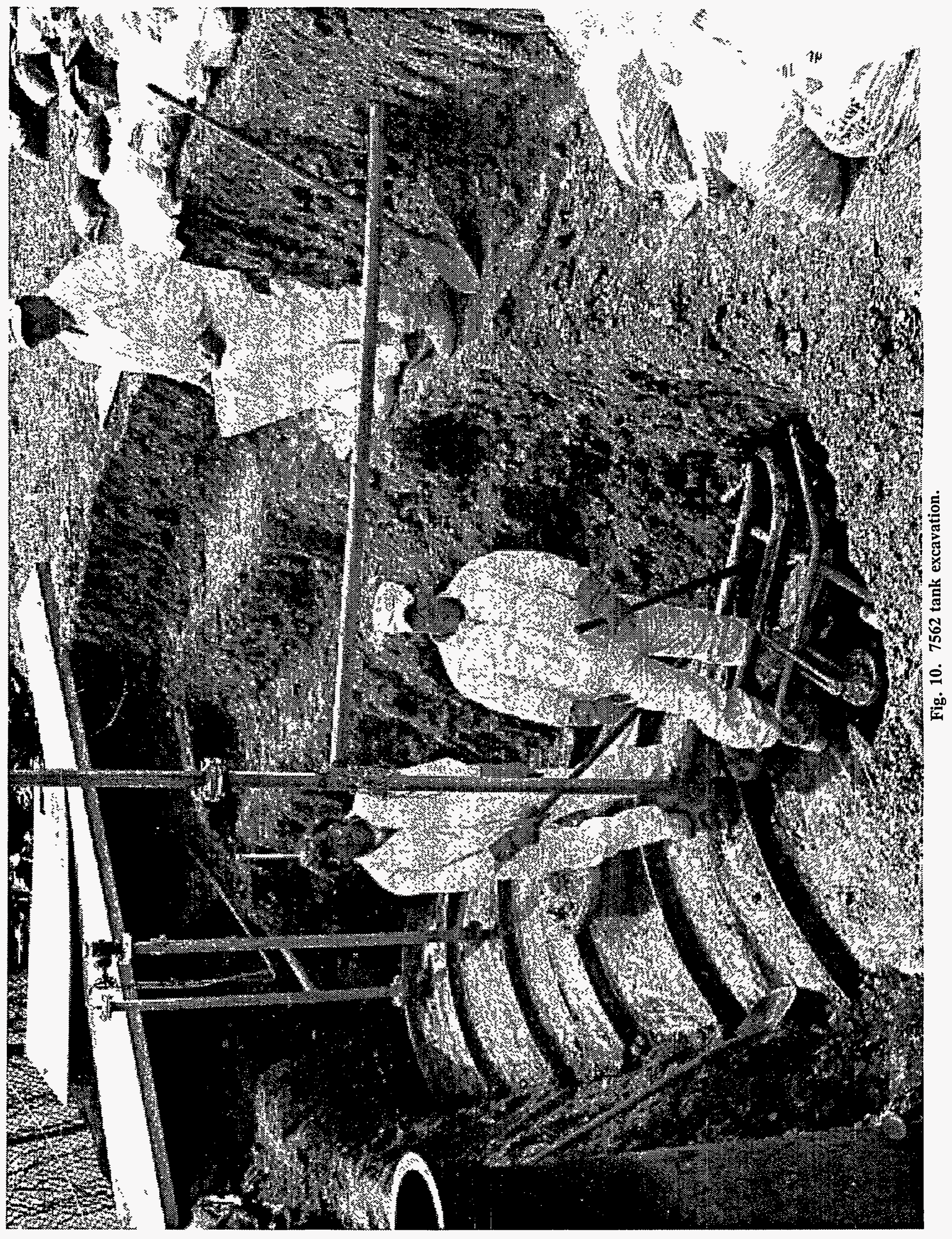




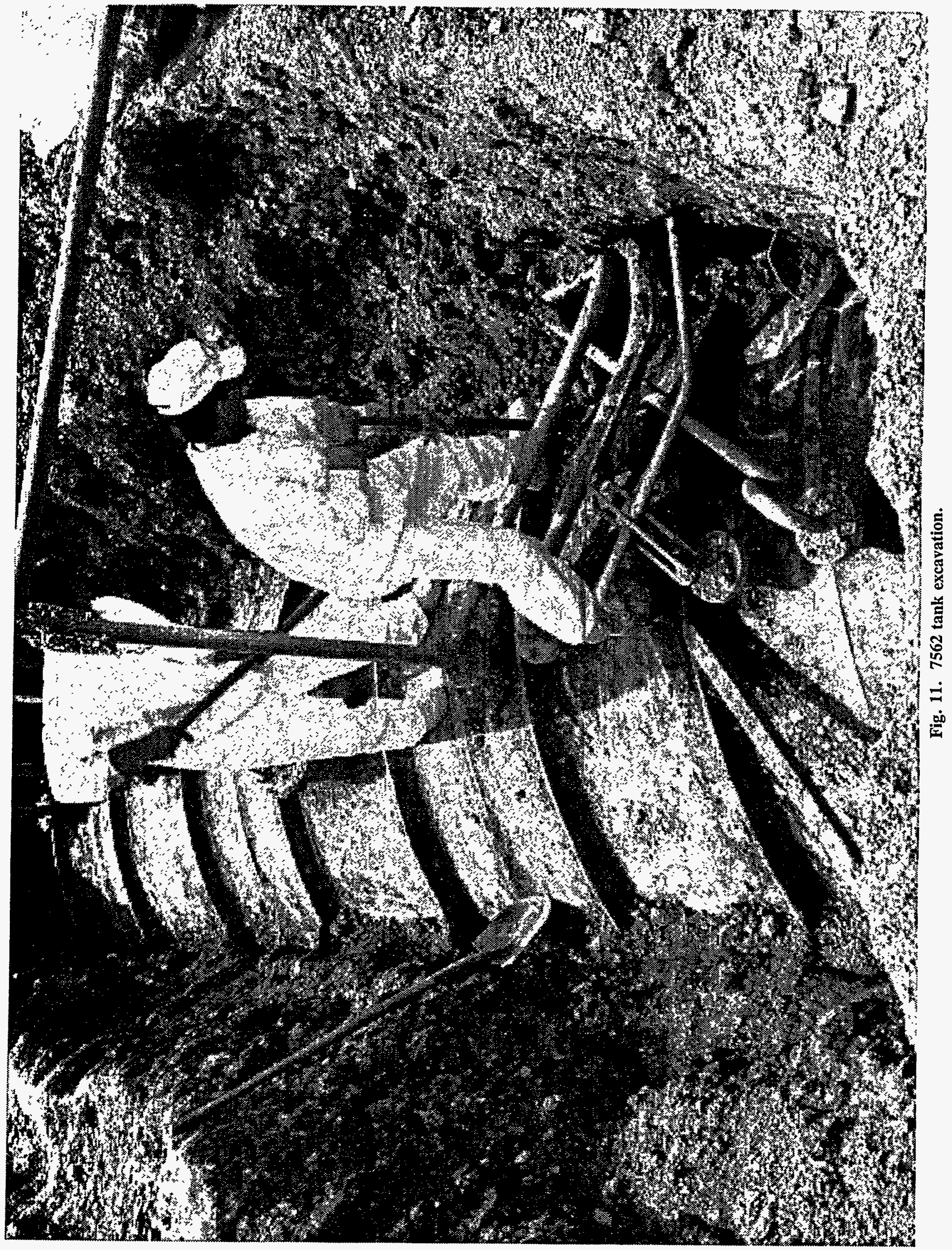




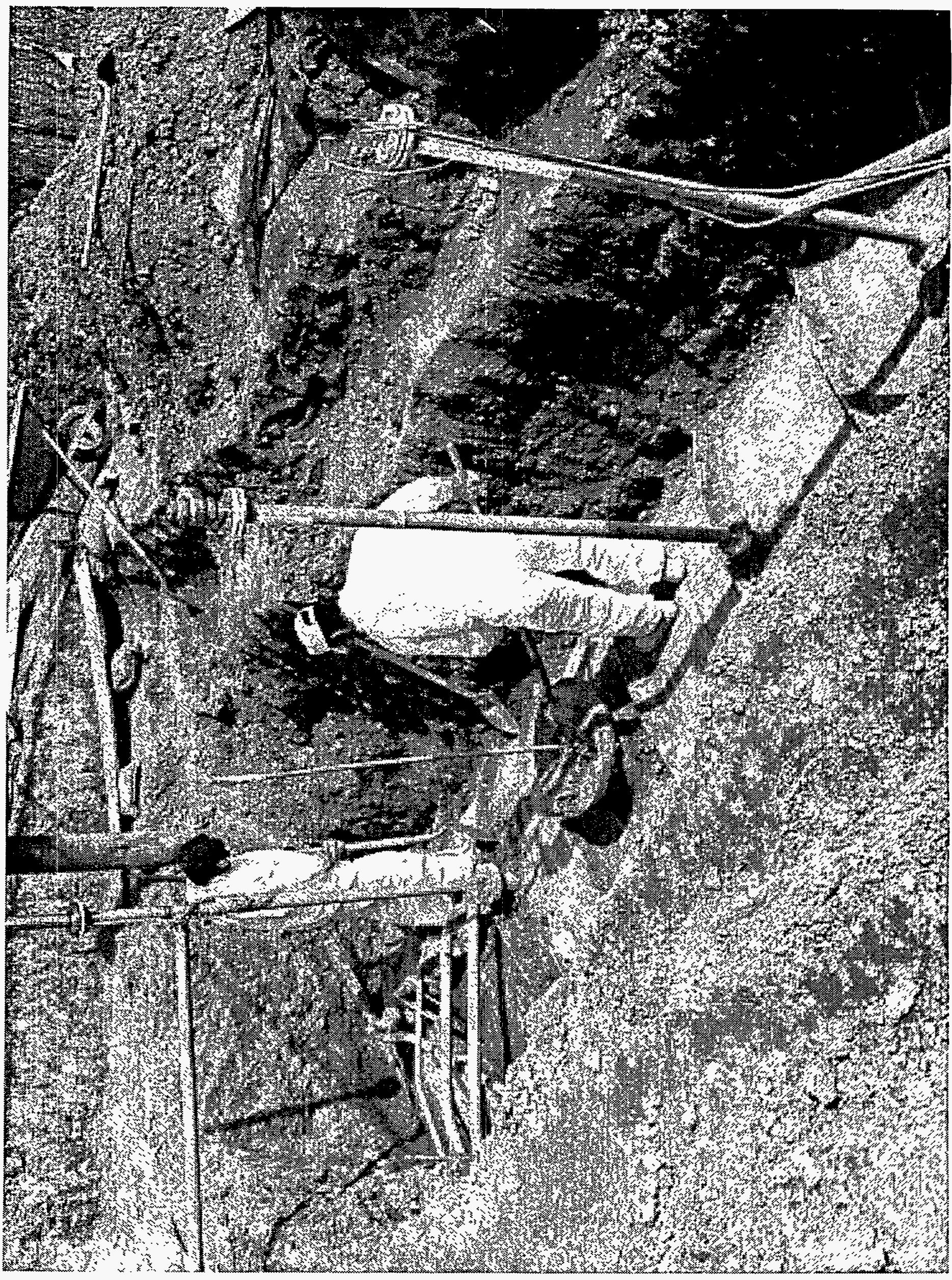


Table 2. FY 1994 occurrence report status

\begin{tabular}{|c|c|c|c|c|c|c|c|}
\hline Occurrence \#/Actlon Item \# & $\begin{array}{l}\text { Fac. } \\
\text { Mgr. }\end{array}$ & Subject & Area/Bldg. & Category* & $\begin{array}{l}\text { Latest } \\
\text { Report }\end{array}$ & $\begin{array}{c}\text { Target } \\
\text { Completion }\end{array}$ & Comment \\
\hline $\begin{array}{l}\text { ORO-MMES-ENVRES-1994-0005 } \\
\text { I0017804 }\end{array}$ & Holder & $\begin{array}{l}\text { Soil contamination found along State } \\
\text { Highway } 95 \text {, adjacent to ORNL }\end{array}$ & $\begin{array}{l}\text { Hwy } 95 \text { - East } \\
\text { Side }\end{array}$ & III & Final & $8 / 31 / 94$ & Closed 07/06/94 \\
\hline $\begin{array}{l}\text { ORO--MMES-ENVRES-1994-0006 } \\
\text { I0017851 }\end{array}$ & Holder & $\begin{array}{l}\text { Suspected petroleum products } \\
\text { discovered in dry well }\end{array}$ & TH-4 Dry Well & III & $\begin{array}{l}\text { 10-day } \\
\text { update }\end{array}$ & $11 / 18 / 94$ & $\begin{array}{l}\text { Extension requested } \\
08 / 12 / 94\end{array}$ \\
\hline $\begin{array}{l}\text { ORO--MMES-ENVRES-1994-0007 } \\
\text { I0015303 }\end{array}$ & Ford & $\begin{array}{l}\text { Personnel contamination at Vent } \\
\text { House Facility }\end{array}$ & 7500 Area & III & Final & $8 / 31 / 94$ & Closed 08/30/94 \\
\hline $\begin{array}{l}\text { ORO--MMES-ENVRES-1994-0008 } \\
10015592\end{array}$ & Holder & $\begin{array}{l}\text { Contamination discovered along } \\
\text { Lagoon Road }\end{array}$ & $\begin{array}{l}\text { Lagoon Road - } \\
\text { adjacent to Bldg. } \\
7819\end{array}$ & III & Final & $8 / 31 / 94$ & Closed 08/30/94 \\
\hline $\begin{array}{l}\text { ORO--MMES-ENVRES-1994-0009 } \\
\text { I0015629 }\end{array}$ & Holder & $\begin{array}{l}\text { Radiologically contaminated water } \\
\text { leak causes unpermitted discharge }\end{array}$ & $\begin{array}{l}3513 \\
\text { Impoundment } \\
\text { Pond }\end{array}$ & mI & Final & $8 / 31 / 94$ & Closed 08/30/94 \\
\hline $\begin{array}{l}\text { ORO--MMES-ENVRES-1994-0010 } \\
\text { I0016266 }\end{array}$ & Hawk & $\begin{array}{l}\text { Contamination discovered at } \\
\text { construction site }\end{array}$ & WAG 9 & III & Final & $8 / 31 / 94$ & Closed 08/30/94 \\
\hline $\begin{array}{l}\text { ORO--MMES-ENVRES-1994-0011 } \\
\text { I0016341 }\end{array}$ & Holder & $\begin{array}{l}\text { Receipt of Notice of Noncompliance } \\
\text { from Tennessee Department of } \\
\text { Environment and Conservation }\end{array}$ & $\begin{array}{l}3513 \\
\text { Impoundment } \\
\text { Pond }\end{array}$ & II & Final & $8 / 31 / 94$ & Closed 08/30/94 \\
\hline $\begin{array}{l}\text { ORO--MMES-ENVRES-1994-0012 } \\
\text { 10016454 }\end{array}$ & Ford & $\begin{array}{l}\text { Unexpected accumulation of fissile } \\
\text { material within primary } \\
\text { conflnement boundaries }\end{array}$ & 7500 Area & III & $\begin{array}{l}\text { 10-day } \\
\text { update }\end{array}$ & 7/31/95 & $\begin{array}{l}\text { Extension requested } \\
08 / 30 / 94\end{array}$ \\
\hline $\begin{array}{l}\text { ORO--MMES-ENVRES-1994-0013 } \\
\text { I0016791 }\end{array}$ & Nelson & WAG 5 contaminated water seepage & WAG 5 & III & Final & $8 / 31 / 94$ & Closed 08/30/94 \\
\hline $\begin{array}{l}\text { ORO--MMES-ENVRES-1994-0014 } \\
\text { I0016915 }\end{array}$ & Wilson & Contaminated tractor & WAG 6 & III & Final & $8 / 31 / 94$ & Closed 08/30/94 \\
\hline
\end{tabular}

\footnotetext{
* Category Codes:

I - Emergency

II - Unusual

III - Off-Normal

IV - Non-Routine
} 


\subsubsection{White Wing Scrap Yard}

Hazardous debris cleanup activities were completed in FY 1994.

\subsection{INACTIVE GROUNDWATER WELLS}

Over the years, groundwater monitoring and investigatory wells were installed to support various study, $R \& D$, and monitoring activities. There are in excess of 6,000 wells on the ORNL site. The scope of this portion of the S\&M Program provides for the management of ORNL groundwater monitoring and investigatory wells that have been identified as unusable or non-essential. These activities are necessary to assist in the prevention of potential contamination and contaminant migration.

\subsubsection{Well Surveillance and Maintenance Activities}

S\&M activities are necessary to cap, lock, and verify the overall integrity and general condition of applicable ORNL groundwater monitoring and investigatory wells (see Fig. 13) that are vulnerable to down-hole contamination. In FY 1994, approximately 400 wells were capped and locked, essentially completing the number of wells currently scheduled for such activities. Since March 1994, S\&M activities including general and downhole condition inspections have been performed on over 2,000 inactive or non-essential wells.

In an attempt to minimize costs, a full printout of all wells which identifies surface and down-hole radiological contamination information at the time of well construction was requested and received. This information, along with fly-over data, is being used to minimize the need for sampling and analysis prior to the issuance of well maintenance work requests. Prior to this approach, before work could commence, at least two samples were required to prove that sites were not radiologically contaminated.

\subsubsection{Well Data Management}

Information pertaining to the current status of all ORNL groundwater monitoring and investigatory wells including location, construction, and S\&M information is maintained by the inactive groundwater well data management program. In FY 1994, a laptop method of data input was developed and implemented. This method involves taking a laptop computer to the field and entering pertinent data as it is generated. As a result, occurrences such as the loss of paperwork, transposition of numbers, and other potential deficiencies have been minimized. The laptop method also provides for the verification of well locations. This is done by comparing the representative location of the well in MapInfo to the physical location of the well in the field. Once the data input and location validation activities are complete, the information is transferred to a diskette and downloaded into the central database system. This method reduces a number of steps and helps to ensure the well data integrity.

Work continues with the groundwater coordinator to develop a single layer within MapInfo that contains all wells located on the ORR. This will enhance both the effectiveness and efficiency of the well program because, as work is being performed on wells under the control of ORNL, the mobilized equipment can accomplish work on wells under the control of others that are in the same general area. 
Appendix A

EVALUATION OF FY 1992 AND FY 1993

WEEKLY SITE/FACILITY INSPECTIONS 



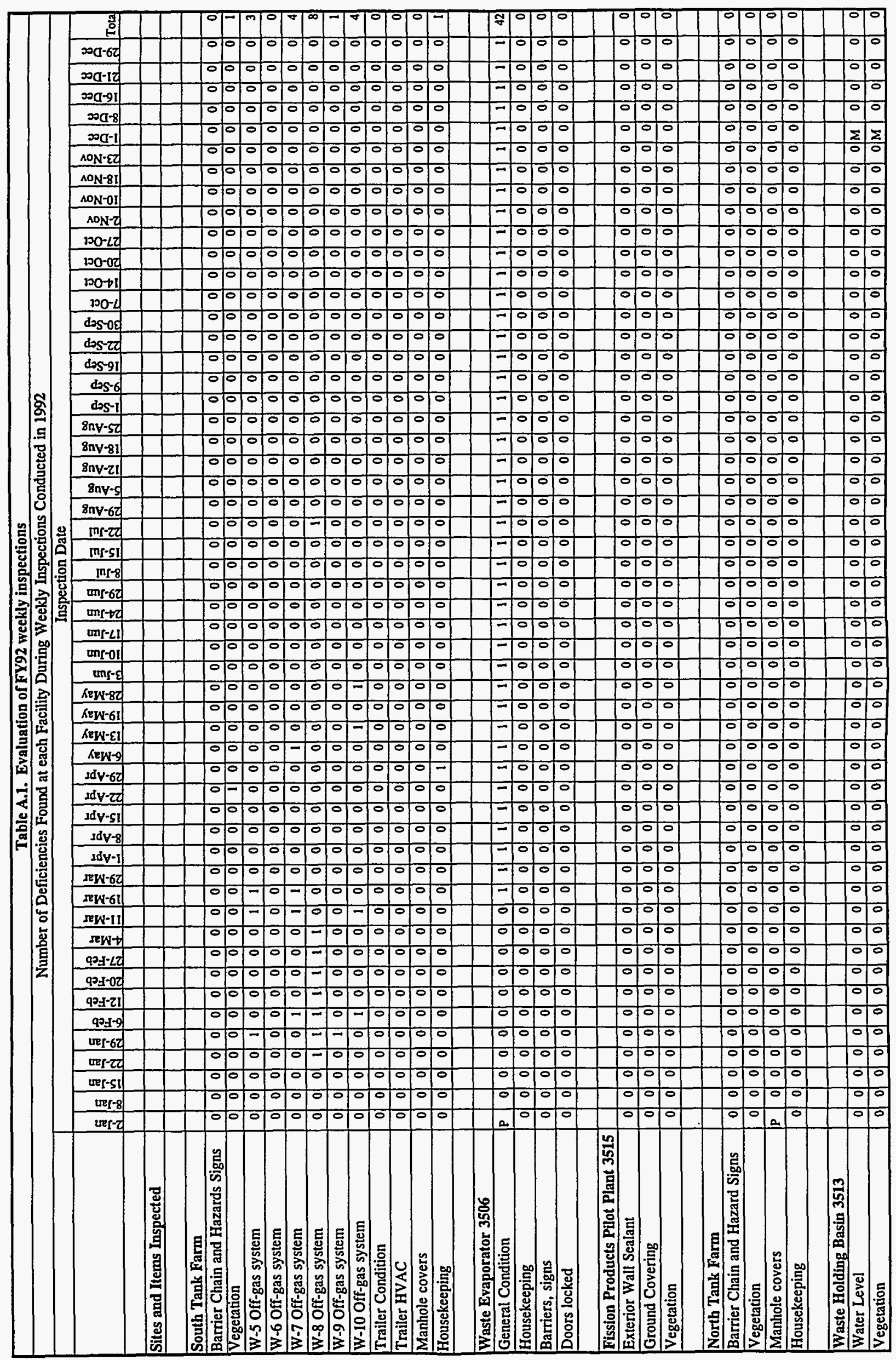




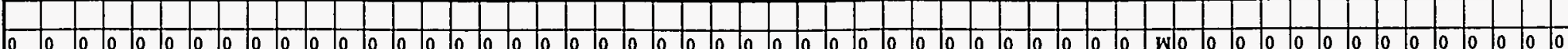

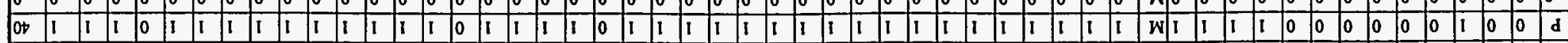

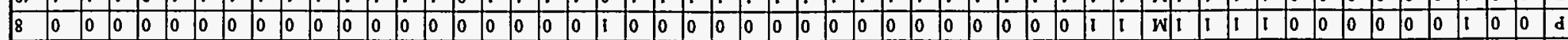

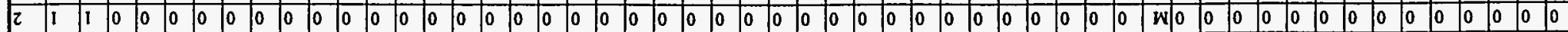

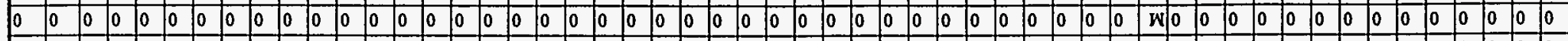

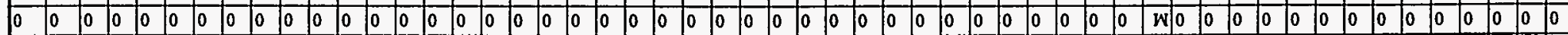

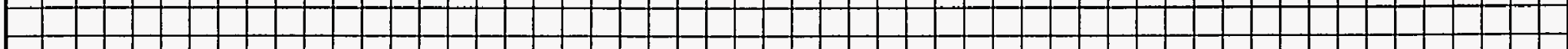

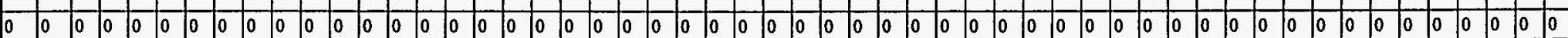

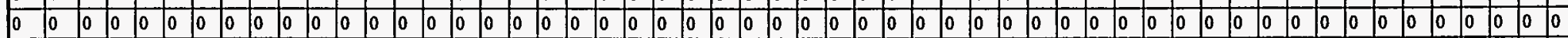

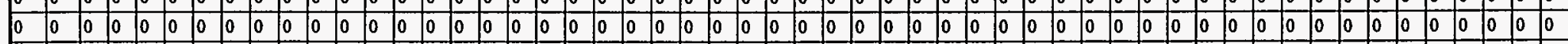

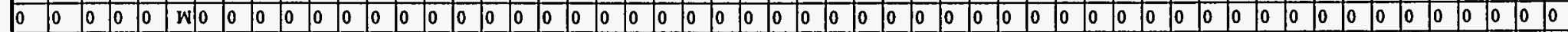

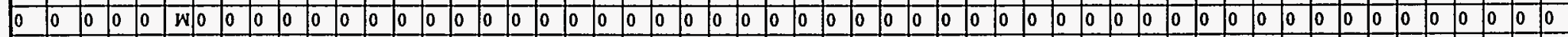
\begin{tabular}{lllllllllllllllllllllllllllllllllllllllllllllllllllllllllllllll}
\hline 0 & 0 & 0 & 0 & 0 & W & 0 & 0 & 0 & 0 & 0 & 0 & 0 & 0 & 0 & 0 & 0 & 0 & 0 & 0 & 0 & 0 & 0 & 0 & 0 & 0 & 0 & 0 & 0 & 0 & 0 & 0 & 0 & 0 & 0 & 0 & 0 & 0 & 0 & 0 & 0 & 0 & 0 & 0 & 0 & 0 & 0 & 0 & 0 & 0 & 0 & 0 & 0 & 0 \\
\hline
\end{tabular}

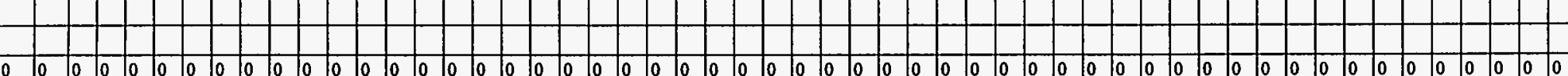

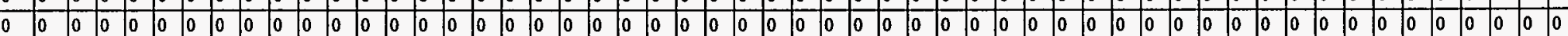

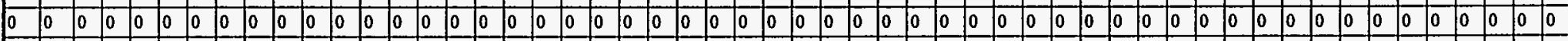

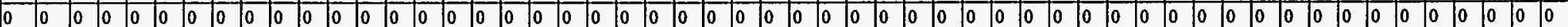
\begin{tabular}{lllllllllllllllllllllllllllllllllllllllllllllllllllllllllllllll}
\hline 0 & 0 & 0 & 0 & 0 & 0 & 0 & 0 & 0 & 0 & 0 & 0 & 0 & 0 & 0 & 0 & 0 & 0 & 0 & 0 & 0 & 0 & 0 & 0 & 0 & 0 & 0 & 0 & 0 & 0 & 0 & 0 & 0 & 0 & 0 & 0 & 0 & 0 & 0 & 0 & 0 & 0 & 0 & 0 & 0 & 0 & 0 & 0 & 0 & 0 & 0 & 0 & 0 & 0 \\
\hline
\end{tabular}

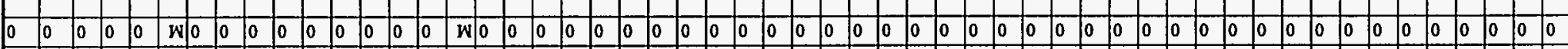

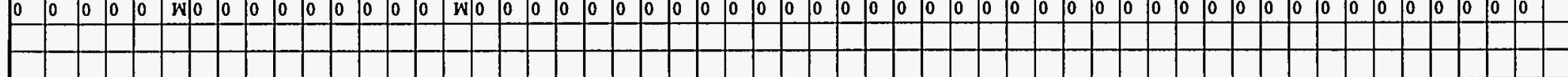

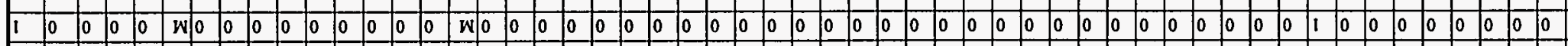

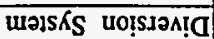

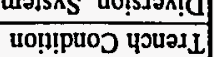

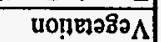
payjo 7 pue pasoij sajeg

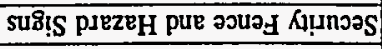
$\checkmark$ \# VSMS

8u!dəวyวsnoH

-

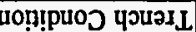
proy ssaosy บоำเวรว $\Lambda$

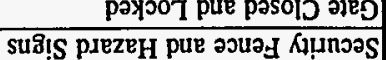
E\# VSMS Su!dəวyวsnoH

-

นо!!!puoj qวuวL proy SSODOY

-

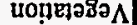

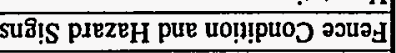
I \# VSMS

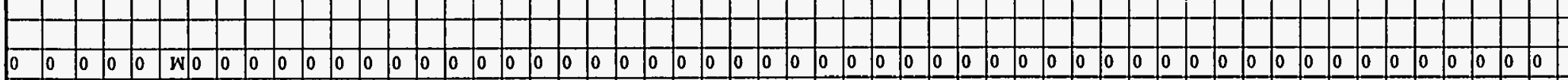

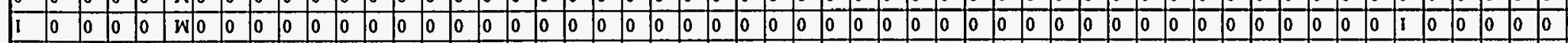

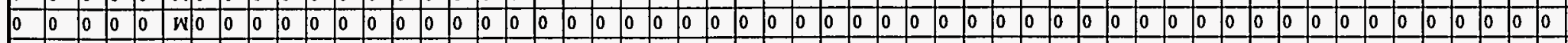

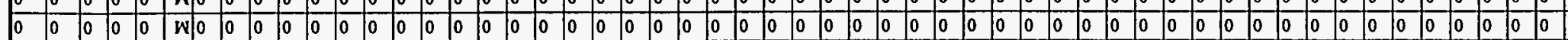

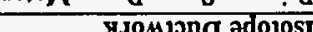

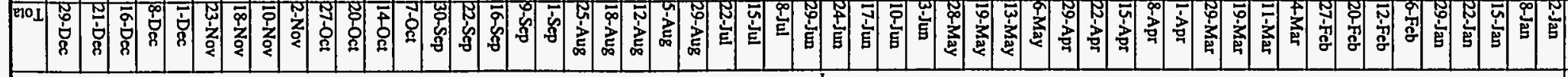
כ18व uonpadsul

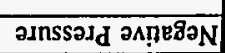
วsnoH मəभเज OIIE

IIPM KI $0 I-5 M$

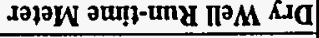

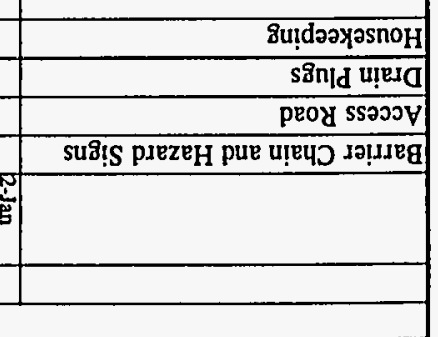




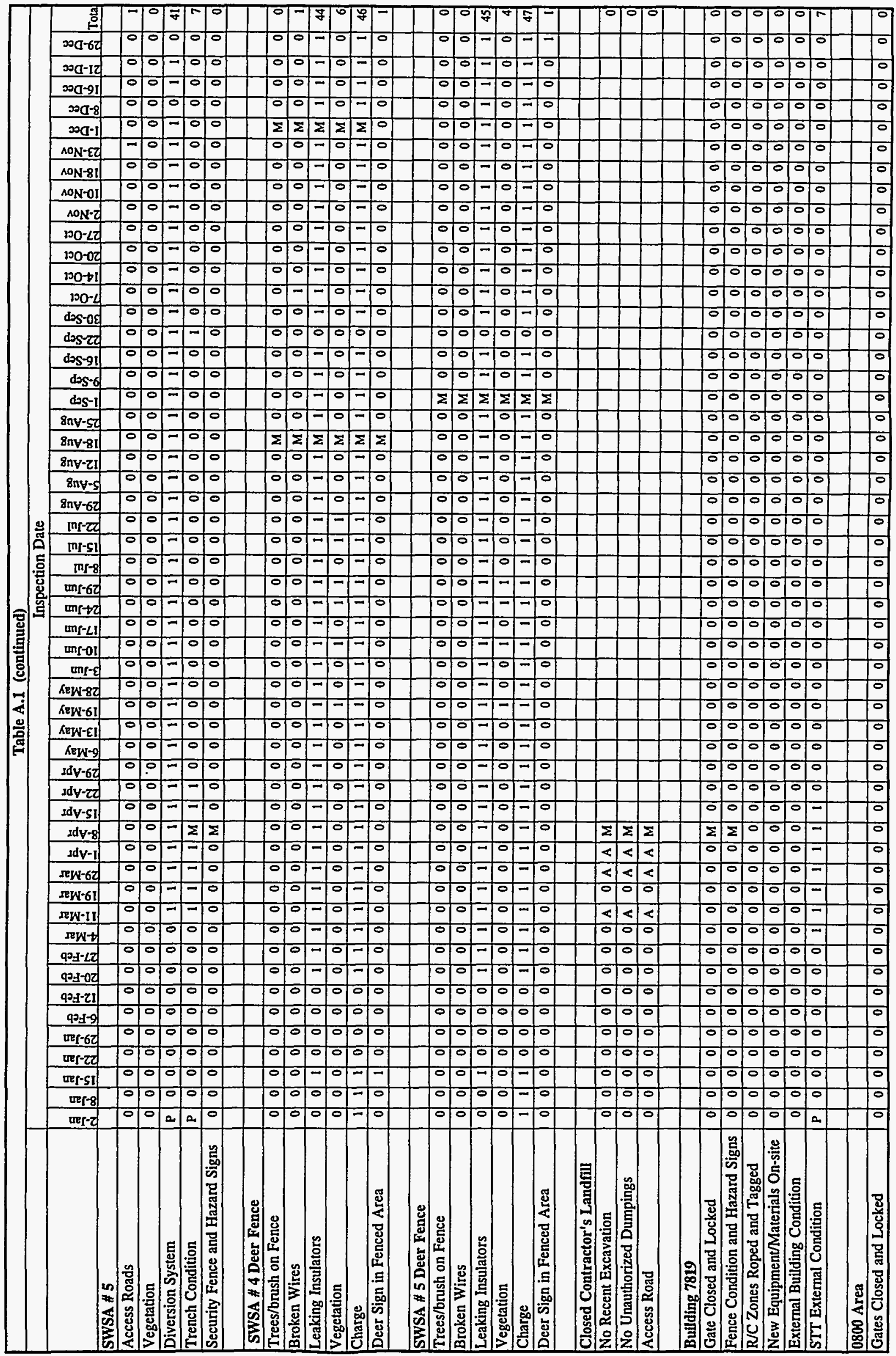




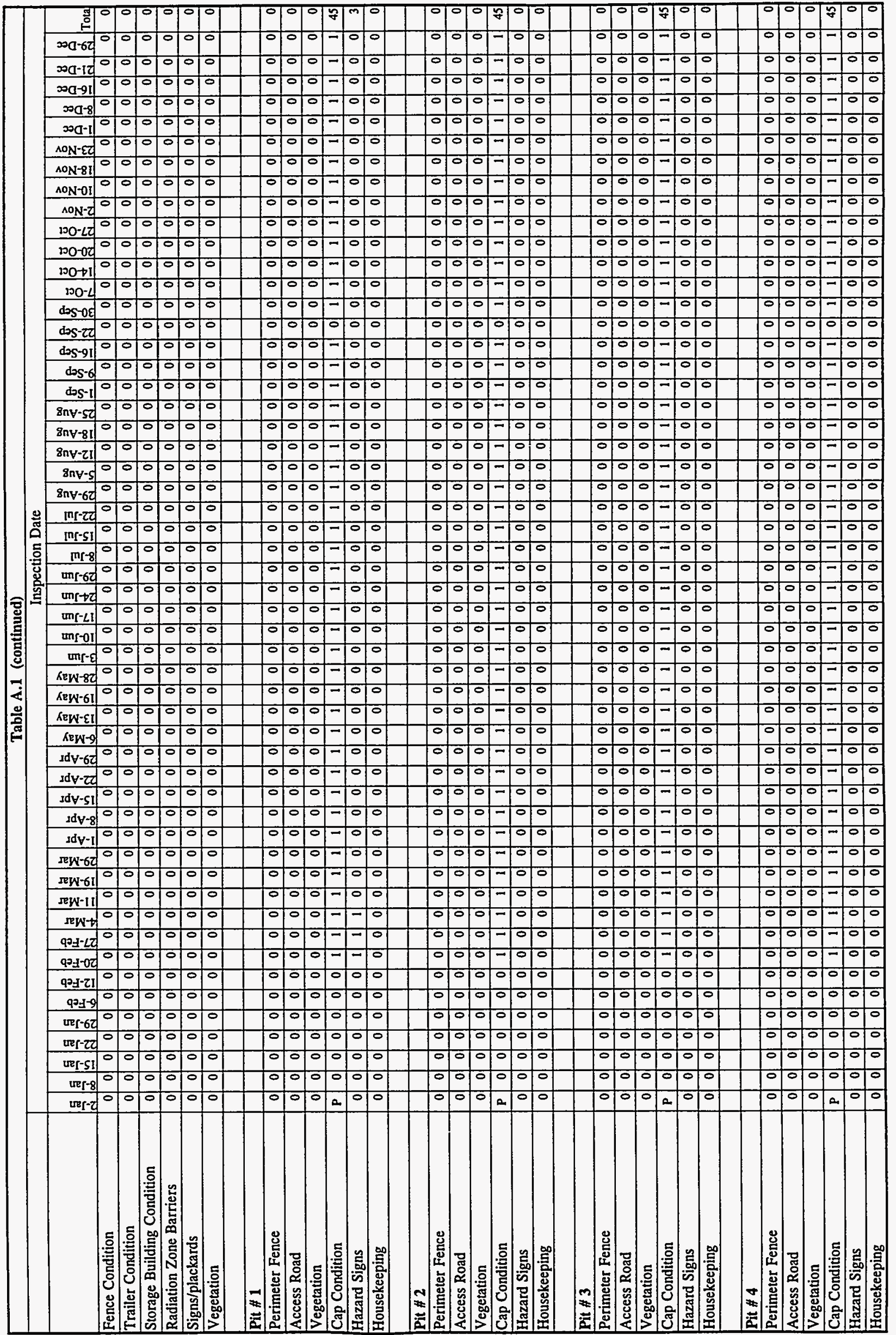




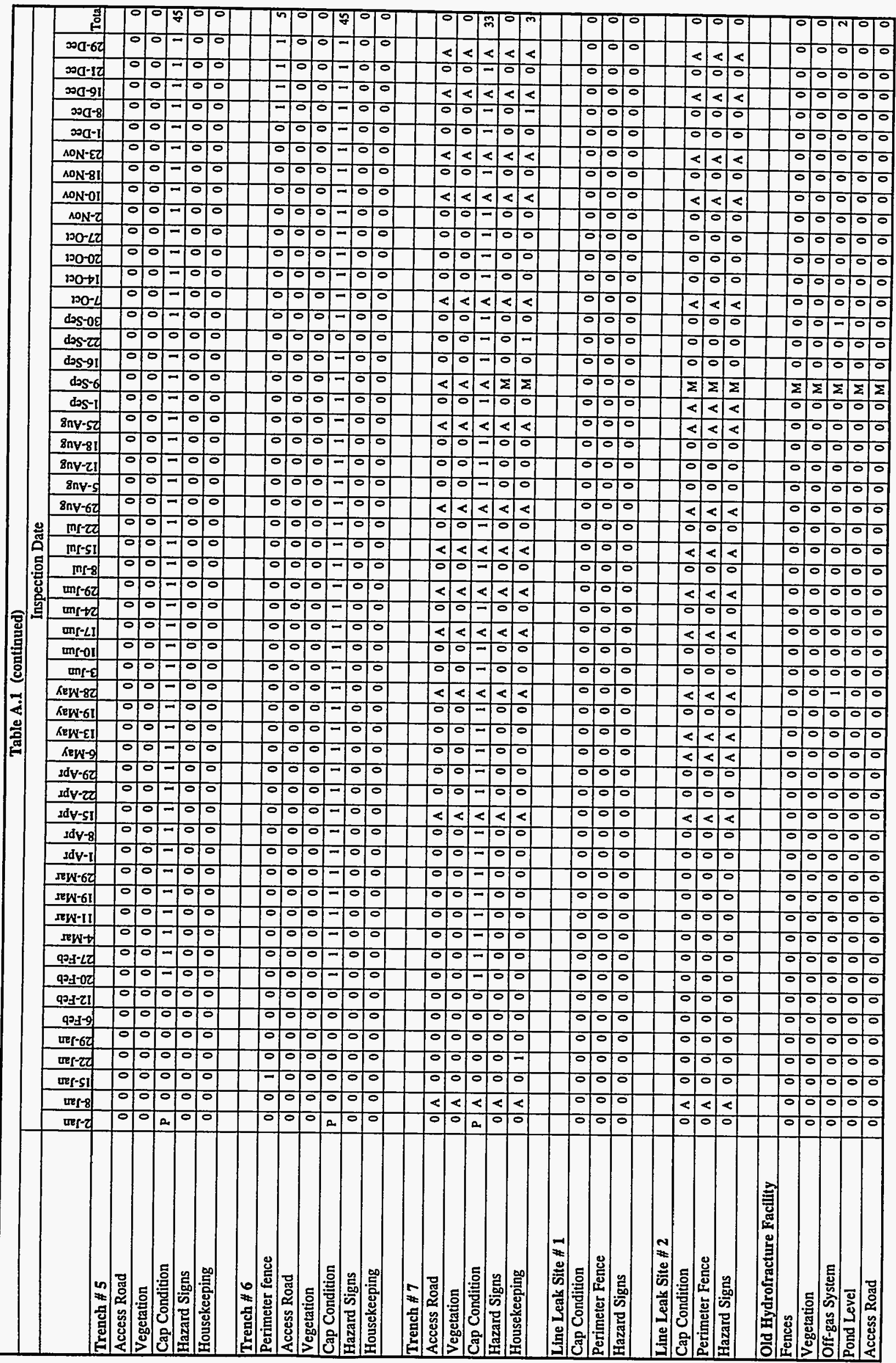




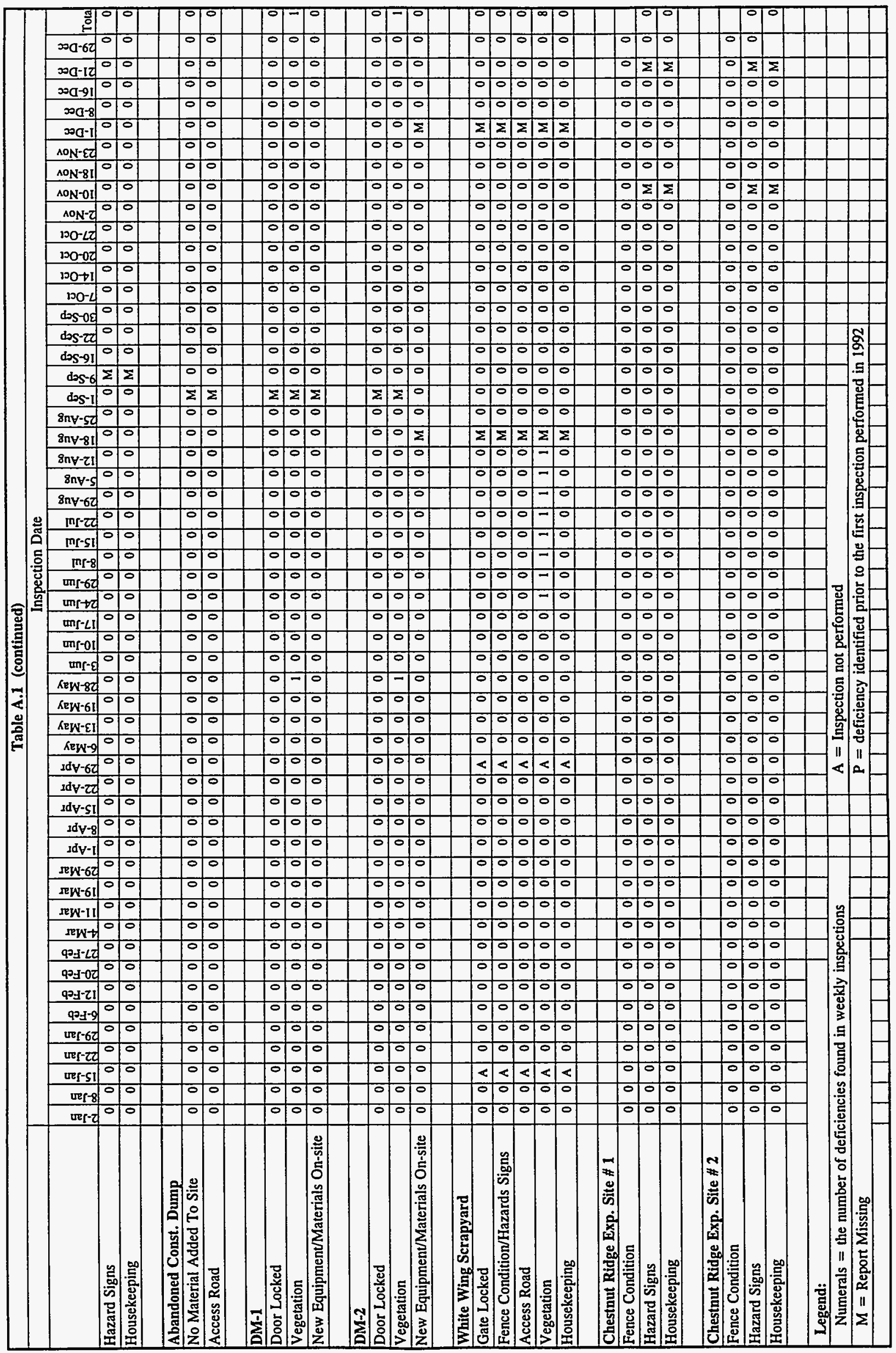




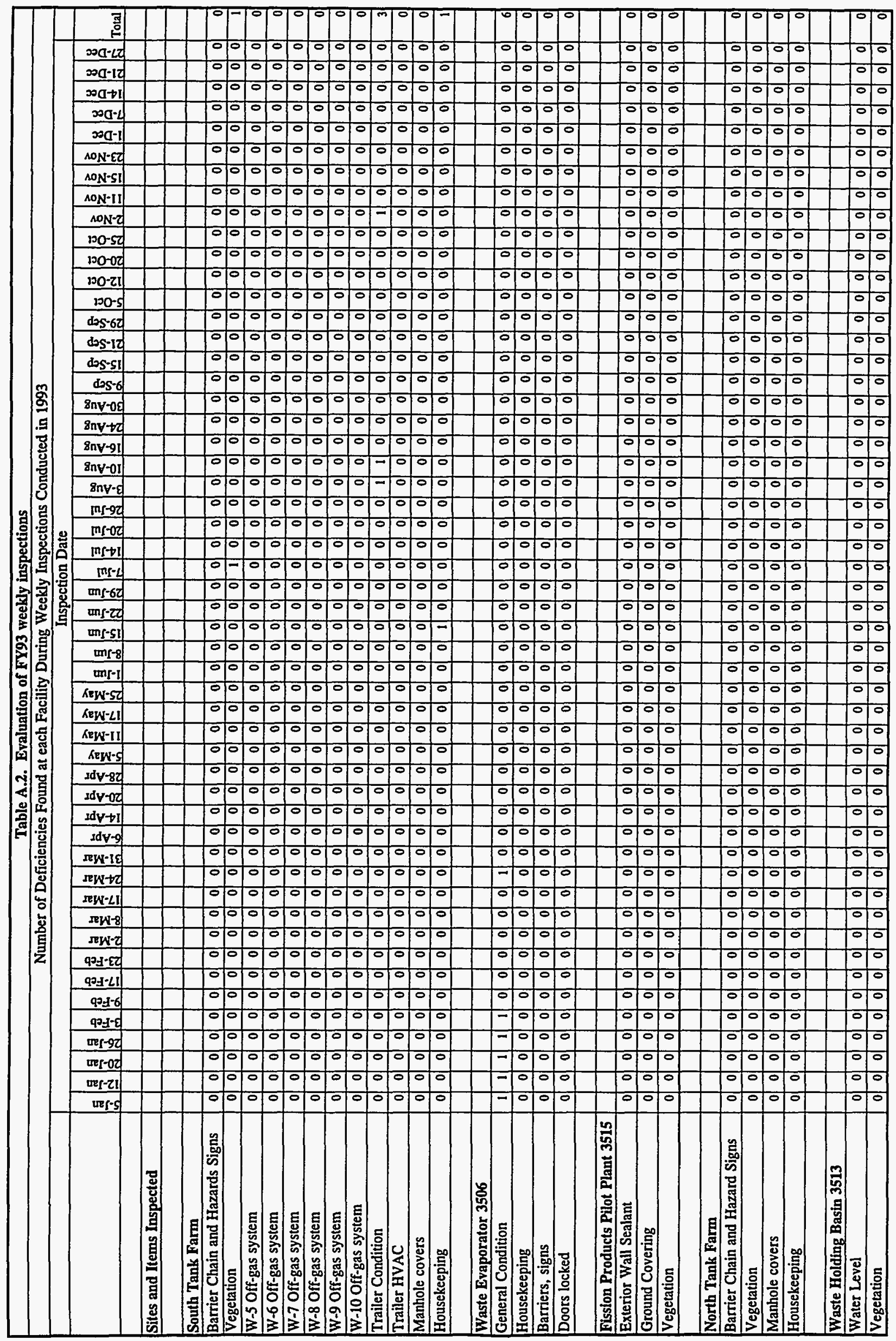




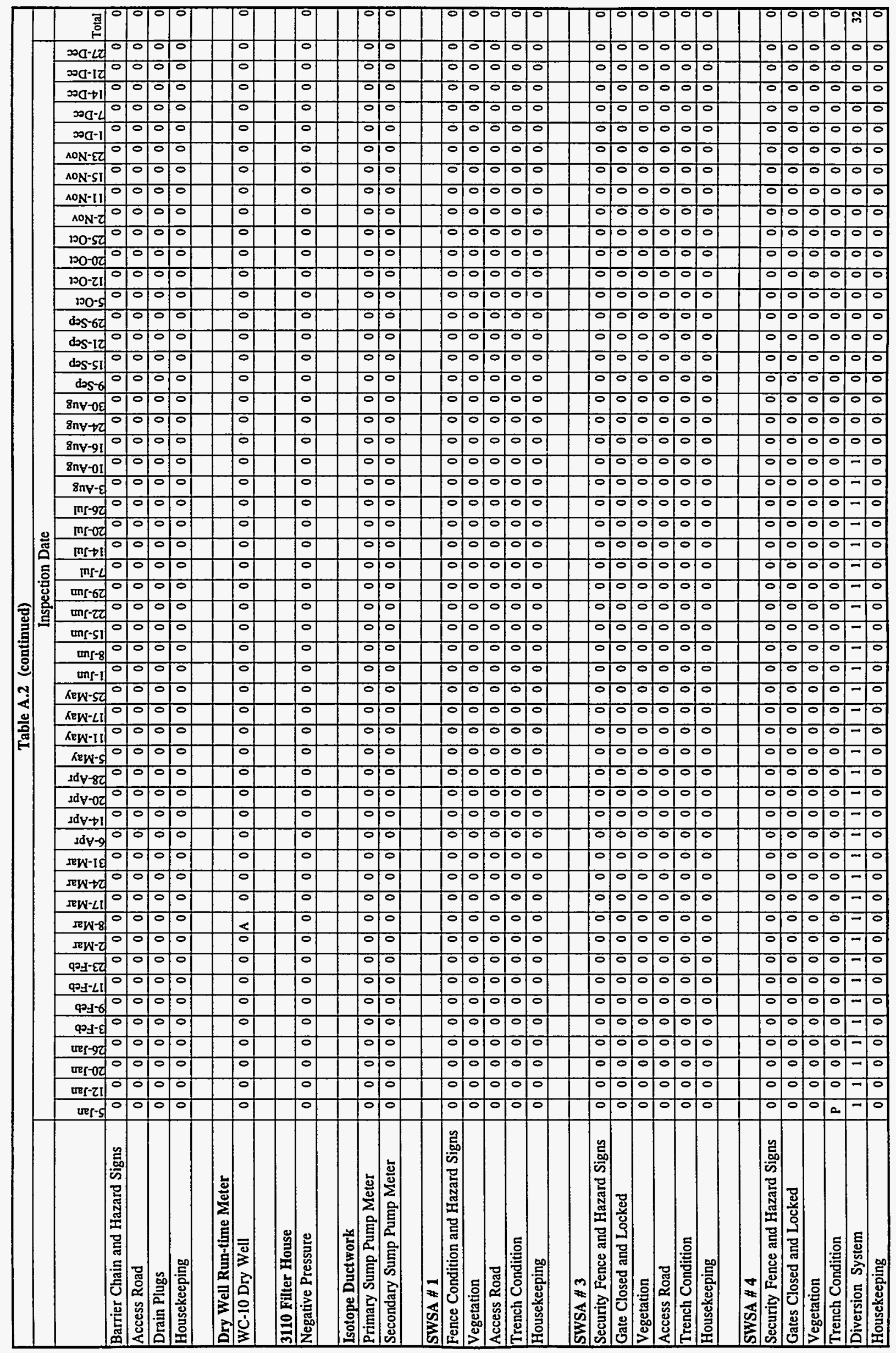




\begin{tabular}{|c|c|c|c|c|c|c|c|c|c|c|c|c|c|c|c|c|c|c|c|c|c|c|c|c|c|c|c|c|c|c|c|c|c|c|}
\hline & 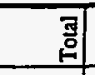 & & $\sigma$ & 50 & ल্ল & |ता & 0 & & & 7 & 0 & त & -7 & का & $\bar{N}$ & & 0 & 10 & $\infty$ & 0 & न्ग & $\pi$ & & $T$ & 010 & 50 & & & 010 & 50 & 10 & 10 & 0 & \\
\hline & $50 \mathrm{a}-\angle \mathrm{a}$ & & 0 & 10 & 10 & 10 & 0 & & & 아 & 0 & 0 & 0 & 01 & 0 & & 0 & 10 & 10 & 0 & $\Rightarrow$ & 0 & & & 00 & 50 & & & 0 & 50 & 0 & 0 & 0 & \\
\hline & $20 \mathrm{~d}-12$ & & 0 & 50 & 0 & 이 & 0 & & & o & 인 & o & 0 & -1 & 0 & & 0 & 0 & 0 & o & $\Rightarrow$ & 0 & & & 0 . & 50 & & & 016 & 50 & 0 & to & 0 & \\
\hline & $\omega_{a \rightarrow 1}$ & & 0 & 10 & 10 & o & 0 & & & of & 0 & 0 & 0 & 01 & 0 & & 0 & 0 & 10 & to & 0 & 0 & & to & . 0 & 50 & & & 010 & 50 & 0 & 10 & 0 & \\
\hline & ra- & & 10 & 10 & 0 & 0 & 0 & & & 0 & 0 & 0 & 0 & 0 & 0 & & 0 & 0 & to & 0 & 0 & 0 & & Ts & 00 & 50 & & & $0 / 0$ & 50 & 10 & 10 & 0 & \\
\hline & $20 \mathrm{~d}-1$ & & 0 & 10 & 0 & o & of & & & of & 0 & 0 & 0 & 0 & 0 & & 0 & 0 & 10 & 10 & 0 & 0 & & The & 0 . & 510 & & & 010 & 00 & 0 & o & to & \\
\hline & 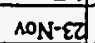 & & 0 & 50 & 0 & of & o & & & - & 0 & 0 & 0 & 016 & 0 & & o & 10 & 10 & 0 & 0 & of & & & 00 & गे० & & & 010 & 010 & 0 & 10 & 10 & \\
\hline & AON-SI & & 0 & 0 & 0 & of & 0 & & & of & 아 & 0 & 0 & 0 & 0 & & 0 & 10 & 0 & 0 & o & 0 & & & 00 & 50 & & & 00 & 10 & 0 & 0 & 0 & \\
\hline & AON-II & & 0 & 10 & 0 & 0 & 0 & & & 아 & 0 & 0 & 0 & 06 & 0 & & 0 & To & 0 & 0 & 0 & 0 & & & 0 . & $\begin{array}{ll}5 & 0\end{array}$ & & & 010 & 50 & 10 & 0 & 0 & \\
\hline & NON-2 & & 0 & 0 & 0 & 이 & 01 & & & 0 & 0 & 0 & 0 & $\begin{array}{ll}0 & \\
\end{array}$ & $=$ & & 0 & 0 & 0 & 0 & 0 & 0 & & & 00 & 50 & & & 0 & 50 & 0 & 0 & 0 & \\
\hline & $200-52$ & & 0 & 0 & 0 & of & 0 & & & 0 & 이 & 0 & 0 & $=10$ & 0 & & 10 & 10 & 0 & 0 & 0 & 10 & & e & 010 & 50 & & & वृ & 50 & 0 & 0 & OO & \\
\hline & 10000 & & 0 & 10 & 0 & of & 0 & & & 이 & 0 & 0 & 0 & $-1 c$ & 0 & & 0 & 0 & 10 & 0 & 0 & 0 & & Te & O10 & ग10 & & & 0 & 50 & 10 & 10 & 10 & \\
\hline & מo-zi & & 0 & 10 & 0 & o & 0 & & & 0 & 0 & 0 & 0 & -10 & 10 & & 0 & 0 & 10 & 0 & 0 & 0 & & 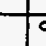 & 00 & 10 & & & 00 & 0 & 0 & 0 & 0 & \\
\hline & $n 0-s$ & & 잉 & 0 & 0 & o & 10 & & & 0 & 0 & 0 & 0 & -76 & 0 & & 10 & 0 & 0 & 0 & 0 & 0 & & F & 00 & 50 & & & 010 & 50 & 10 & 10 & 10 & \\
\hline & $d x-60$ & & 0 & 10 & 0 & 0 & 0 & & & 0 & 0 & 0 & 0 & 01 & $=$ & & 0 & 0 & 0 & 0 & $=$ & 0 & & & 00 & 50 & & & 0 & 10 & 0 & 0 & 0 & \\
\hline & dos-Id & & 0 & 0 & 0 & 0 & 0 & & & 아 & 0 & 0 & 0 & -10 & 0 & & 0 & 0 & 0 & 0 & 0 & $=$ & & & 010 & 50 & & & 010 & 10 & 10 & 0 & 0 & \\
\hline & $d s s-s t$ & & 0 & 0 & 0 & 0 & \% & & & 아 & 0 & 0 & 0 & $-{ }^{\circ}$ & 0 & & 0 & - & 0 & 0 & $=$ & 0 & & te & $\begin{array}{l}0 \\
\end{array}$ & 510 & & & 010 & 50 & to & 10 & 0 & \\
\hline & dos-6 & & 0 & 10 & 0 & -1 & 0 & & & 0 & 0 & 아 & 0 & $\Rightarrow c$ & 0 & & 0 & 0 & 0 & 0 & 0 & 0 & & & 00 & to & & & 00 & 0 & 0 & 0 & 0 & \\
\hline & 8nv-os & & 0 & 10 & 0 & $=1$ & O & & & of & of & 이 & 0 & $\Rightarrow c$ & 0 & & 0 & 10 & 0 & 0 & 0 & $=$ & & c & 00 & 50 & & & 00 & 50 & fo & 0 & 0 & \\
\hline & $8 n y+c$ & & 10 & 0 & 0 & 0 & 0 & & & 잉 & 이 & 0 & 0 & -10 & 0 & & 0 & To & 10 & 0 & 0 & 0 & & & 00 & 0 & & & 0 & 0 & 10 & To & 0 & \\
\hline & 8nv-91 & & 0 & 0 & 0 & 0 & 0 & & & - & of & 0 & 0 & \begin{tabular}{l|l}
0 &
\end{tabular} & 0 & & 0 & 0 & 0 & 0 & 0 & 0 & & & 0 & 50 & & & 00 & 0 & 0 & 0 & 0 & \\
\hline & 8nv-0i & & 0 & 0 & $=$ & 0 & 0 & & & 0 & 0 & 아 & 0 & -10 & $\overline{0}$ & & 0 & 10 & 0 & 0 & 0 & 0 & & c & 00 & 50 & & se & 0 & 0 & 10 & O & 0 & \\
\hline & $8 n y-\varepsilon$ & & 10 & 0 & $=$ & 0 & 0 & & & 0 & 0 & 0 & 0 & $-7 c$ & 0 & & 0 & 0 & 0 & 0 & 0 & 0 & & 5 & 010 & 50 & & & 0 & 10 & 10 & 0 & 0 & \\
\hline & [n[-9] & & 10 & 0 & $=$ & 0 & 0 & & & of & 0 & 0 & 0 & \begin{tabular}{l|l}
0 & 6 \\
\end{tabular} & 0 & & 0 & 10 & 0 & 0 & 0 & 0 & & 6 & 00 & 50 & & & 0 & 0 & 0 & 0 & 0 & \\
\hline & [n[-0) & & 10 & 0 & $=$ & 0 & 0 & & & 0 & of & 0 & $=$ & -16 & $\overline{0}$ & & 10 & $\Rightarrow$ & 0 & 0 & $=$ & 0 & & $e^{\circ}$ & $5 / 0$ & 50 & & & 0.0 & 10 & O & 0 & 0 & \\
\hline ळัँ & {$\left[n_{5} \rightarrow 1\right.$} & & 10 & 10 & $\sigma$ & O & 0 & & & 0 & of & of & 0 & $\Rightarrow 0$ & 0 & & to & $\Rightarrow$ & O & 0 & $=$ & 0 & & e & 00 & 50 & & & 0 & 0 & 0 & 0 & 0 & \\
\hline 5 & $m[-L$ & & 10 & 10 & $1-$ & 01 & 0 & & & 이 & 0 & 0 & 0 & -10 & 0 & & 0 & - & 0 & 0 & - & 0 & & e & 00 & 50 & & $e^{\circ}$ & 010 & 0 & 10 & 0 & 0 & \\
\hline 'ֶू & ans-6t & & 10 & 0 & $=$ & Oo & 0 & & & of & o & 0 & $\begin{array}{ll}0 \\
\end{array}$ & -10 & 0 & & 0 & -1 & 0 & 아 & $=$ & 0 & & e & 50 & 10 & & e & 610 & 10 & 0 & 0 & 10 & \\
\hline : & นn!-zz) & & o & 0 & $1=$ & व & 0 & & & of & of & -1 & 0 & -10 & O & & 0 & O० & 0 & 0 & $=$ & 0 & & e & 5 & 50 & & 5 & 0 & to & 0 & 0 & 0 & \\
\hline & แnI-SI & & 0 & 0 & - & of & 0 & & & 0 & 0 & -7 & 0 & -10 & 0 & & 0 & - & 0 & 0 & $=$ & 0 & & c & 50 & 0 & & $\bar{c}$ & 010 & 10 & 10 & 0 & 0 & \\
\hline & $\operatorname{lom}[-8$ & & 10 & o & - & 0 & 0 & & & 0 & 0 & -1 & 0 & -10 & 0 & & 0 & 0 & 0 & 0 & $=$ & 0 & & e & 50 & 10 & & $\bar{c}$ & 010 & 0 & 10 & 0 & 0 & \\
\hline & unf-1 & & 0 & 0 & -7 & 0 & 0 & & & - & of & -1 & 0 & -10 & 0 & & 0 & 0 & 0 & 0 & $=$ & 0 & & e & 50 & 50 & & es & \begin{tabular}{l|l}
0 \\
\end{tabular} & 0 & 10 & 0 & 0 & \\
\hline$y$ & Kew-sed & & 0 & 0 & - & 10 & 0 & & & - & of & $=$ & 0 & -10 & 0 & & 0 & 0 & 0 & 0 & - & 0 & & c & 50 & 0 & & 8 & 010 & 0 & 0 & 0 & 0 & \\
\hline & KEW- $L I$ & & 10 & 10 & 7 & 0 & 0 & & & 0 & 0 & $=$ & 0 & \begin{tabular}{l|l}
-6 \\
\end{tabular} & 0 & & 0 & 0 & 0 & 0 & $=$ & O & & e & 50 & 50 & & $\bar{c}$ & 610 & 10 & 0 & 10 & 0 & \\
\hline & KEW-II & & 10 & 0 & - & 10 & 0 & & & 0 & 0 & -1 & 0 & -10 & 0 & & 0 & 0 & -7 & 0 & - & 0 & & $\sqrt{c}$ & 50 & 50 & & 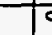 & 010 & 10 & 0 & 0 & 0 & \\
\hline & Kew-S & & 0 & 0 & 7 & 0 & 0 & & & - & 0 & 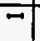 & 0 & -10 & 0 & & 0 & 0 & $=$ & 0 & $=$ & 0 & & c & 50 & 10 & & c & 0 & 0 & 0 & 0 & 0 & \\
\hline & $2 d v-8 z$ & & 0 & 10 & $=$ & 0 & 0 & & & o & $\overline{0}$ & $\Rightarrow$ & 0 & -10 & 0 & & 0 & 0 & $\rightarrow$ & 0 & $=$ & 응 & & ${ }^{\circ}$ & 50 & 50 & & $\bar{c}$ & 010 & 0 & O & 0 & 0 & \\
\hline & Idv-od & & 10 & To & 7 & 0 & 0 & & & of & 0 & -1 & 0 & -10 & 0 & & 0 & 0 & $=$ & 0 & $=$ & 0 & & $e^{\circ}$ & 50 & 10 & & 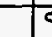 & $\begin{array}{ll}0 & 0\end{array}$ & 0 & 0 & 0 & 0 & \\
\hline & $2 d v+1$ & & To & 0 & $=$ & 0 & 0 & & & $\bar{z}$ & $\Sigma$ & $z$ & $\sum$ & $\Sigma 1$ & $\bar{\Sigma}$ & & $\Sigma$ & $z$ & $\Sigma$ & $\Sigma$ & $\Sigma$ & $\Sigma$ & & c & 50 & 10 & & c & 00 & 0 & 0 & 0 & 0 & \\
\hline & Idv-g & & 0 & 0 & -7 & of & 0 & & & $\overline{0}$ & 0 & -1 & $\circ$ & -6 & $\overline{0}$ & & 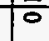 & O० & $\Rightarrow$ & 0 & $=$ & 음 & & a & 50 & 10 & & a & 80 & 10 & 10 & 10 & of & \\
\hline & มีW-If & & o & O & - & 10 & 0 & & 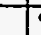 & o & 0 & $\Rightarrow$ & 0 & $7 c$ & 0 & & 0 & 0 & $\Rightarrow$ & 0 & $\Rightarrow$ & $\sigma$ & & e & 50 & 0 & & 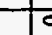 & 010 & 0 & to & 0 & 0 & \\
\hline & $x w+2$ & & 0 & 0 & $=$ & 0 & 0 & & 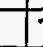 & $=$ & O & -1 & 0 & -10 & б & & 0 & 0 & $\Rightarrow$ & o & $\Rightarrow$ & 0 & & e & 50 & 0 & & $c$ & 50 & 0 & 0 & 0 & 0 & \\
\hline & IEW-LI & & 0 & 10 & - & 01 & 0 & & 7 & 0 & $\overline{0}$ & -1 & 0 & $-7 c$ & o & & 0 & 0 & -1 & 0 & $=$ & 0 & & $\bar{c}$ & 50 & 0 & & $c$ & 50 & 0 & 0 & 10 & 0 & \\
\hline & sew-8 & & 0 & 0 & -7 & 0 & 0 & & Fa & o & 0 & -9 & 0 & $=10$ & 0 & & 0 & 0 & $\Rightarrow$ & 0 & $=$ & 0 & & a & 0 & 10 & & $c$ & 00 & 0 & O & 0 & o) & \\
\hline & s.w-2 & & 0 & 0 & - & 0 & 0 & & 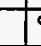 & का & 0 & $\Rightarrow$ & 0 & $\begin{array}{lll}-1 & 0\end{array}$ & O & & 0 & 10 & $\Rightarrow$ & 0 & - & $\sigma$ & & c & 50 & 10 & & $c$ & 50 & 10 & 0 & 0 & 0 & \\
\hline & $q 2 \mathrm{~A}-\varepsilon d$ & & 0 & 0 & - & 01 & 0 & & 7 & का & 0 & -1 & 0 & -10 & o & & 0 & 0 & -7 & 0 & -10 & 0 & & e & 0 & 0 & & c & 50 & 10 & 10 & 0 & of & \\
\hline & $905-\angle t$ & & 10 & 0 & - & 10 & 0 & & 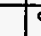 & 5 & 0 & -1 & 0 & -70 & $\sigma$ & & 0 & of & $\Rightarrow$ & of & $\Rightarrow$ & o & & c & 50 & 10 & & 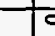 & 50 & To & 0 & 0 & of & \\
\hline & $90.1-6$ & & 0 & 0 & - & 01 & 0 & & T & का & 0 & -1 & 0 & $=0$ & 0 & & 0 & 0 & -7 & 0 & $=1$ & 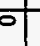 & & e & 50 & 0 & & $c$ & 50 & 0 & 0 & 0 & 0 & \\
\hline & $q 2 y-g$ & & 10 & 0 & - & 0 & 0 & & & of & 0 & $\Rightarrow$ & 0 & $\Rightarrow 0$ & 0 & & 0 & 0 & -1 & 0 & -12 & 0 & & a & 5 & 10 & & c & 50 & 10 & O & 0 & 0 & \\
\hline & पाएव $-9 z$ & & 0 & 0 & $=$ & 0 & 0 & & & of & $\sigma$ & -1 & 0 & -10 & o & & 0 & O० & -1 & 0 & -10 & o & & c & 50 & 10 & & c & 80 & 0 & O & 0 & of & \\
\hline & पri-0d & & 0 & 0 & - & 0 & 0 & & te & क & of & -1 & 0 & -10 & 0 & & 0 & 0 & -1 & of & - & $\sigma$ & & c & 50 & 10 & & c & 510 & 10 & 0 & 0 & of & \\
\hline & पर[-ZI & & 0 & 0 & $=$ & 0 & 0 & & 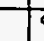 & ㄱ & 0 & -1 & 0 & $\Rightarrow 0$ & $\sigma$ & & 0 & 0 & -1 & 0 & $\Rightarrow$ & 0 & & e & 50 & 0 & & c & 50 & 10 & 0 & 0 & 0 & \\
\hline & urer-s & & 0 & 0 & -1 & 01 & 0 & & & का & 0 & -1 & 0 & -10 & $\sigma$ & & 0 & O & -1 & of & -10 & o & & c & 10 & 10 & & 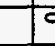 & 50 & 10 & 0 & 0 & 0 & \\
\hline & & & 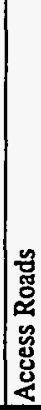 & 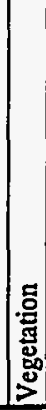 & 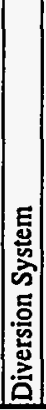 & 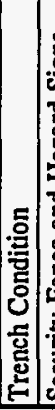 & 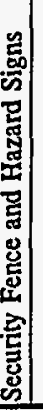 & & 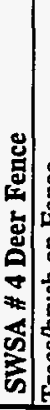 & & 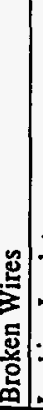 & 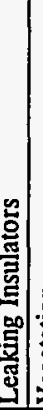 & 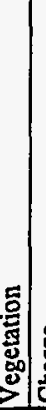 & 焉 & 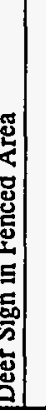 & 象 & 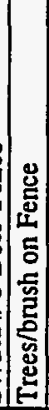 & 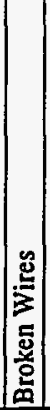 & 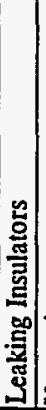 & 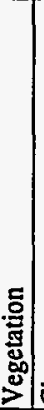 & 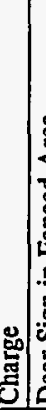 & 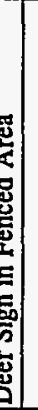 & & 它 & 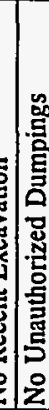 & 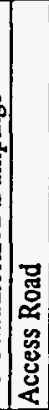 & & 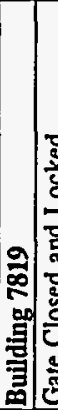 & 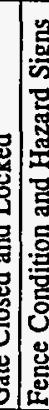 & 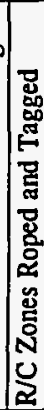 & 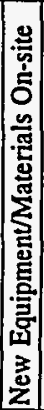 & 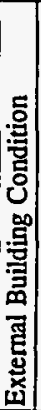 & 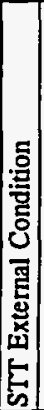 & \\
\hline
\end{tabular}




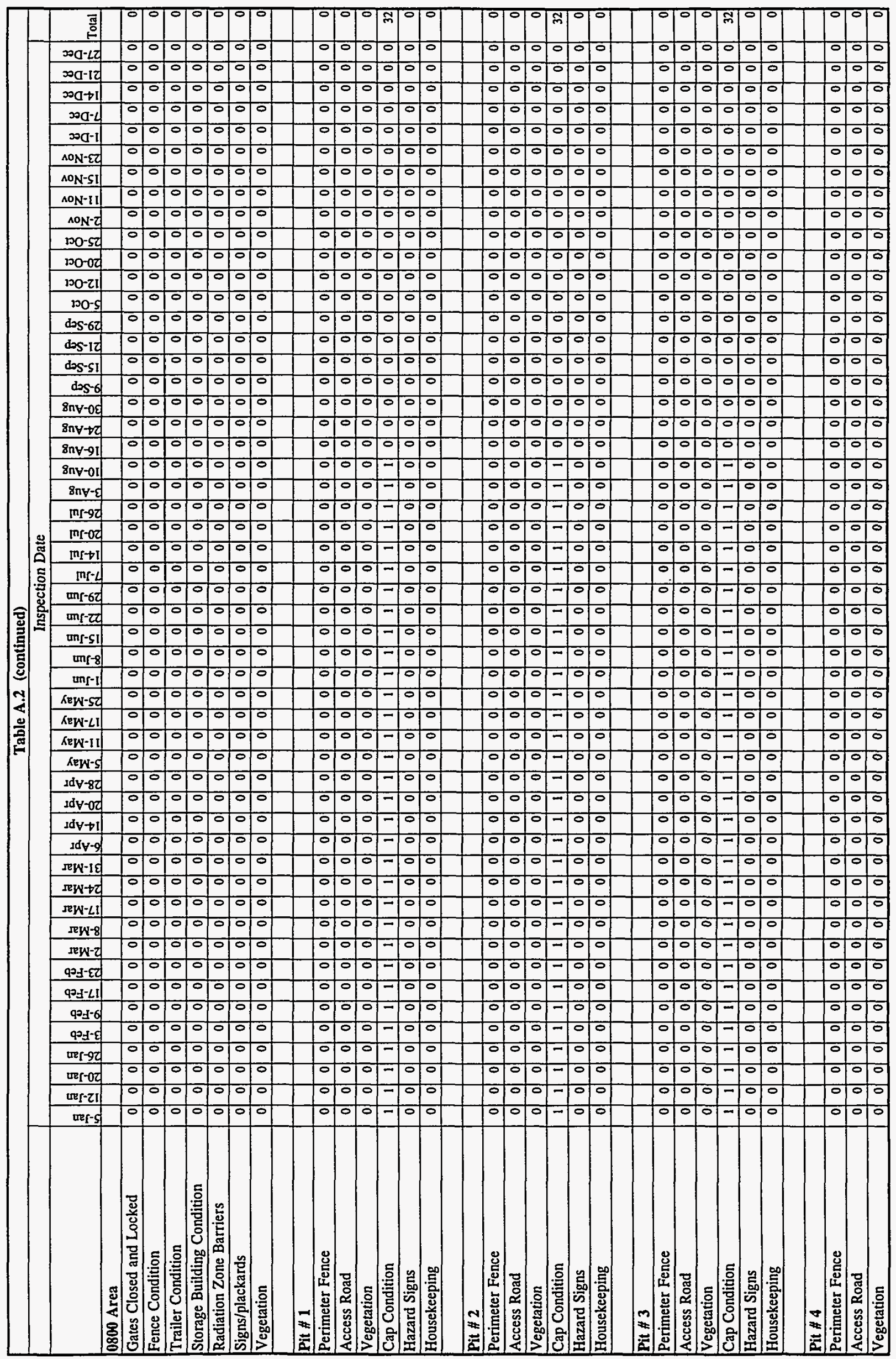




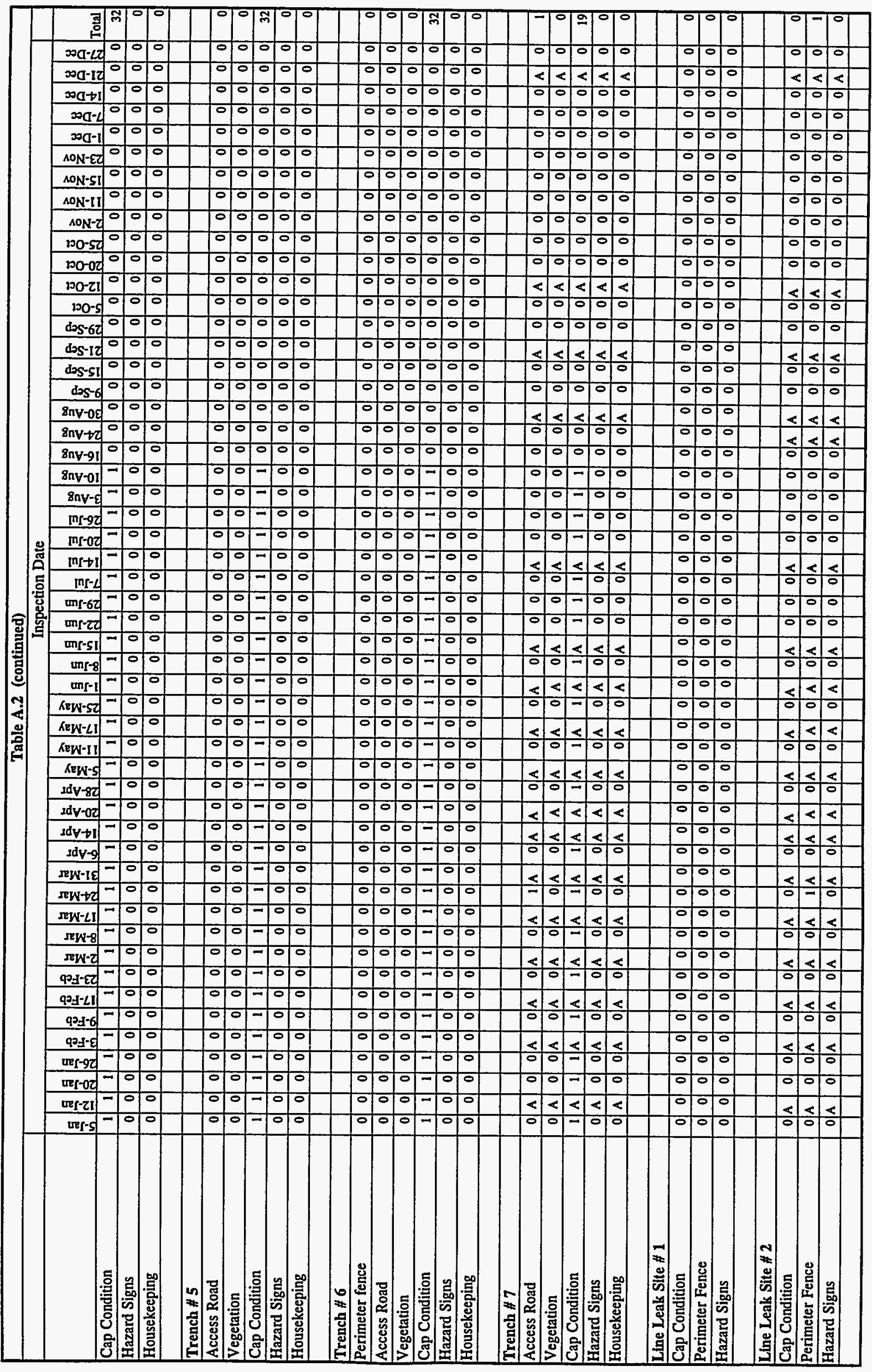




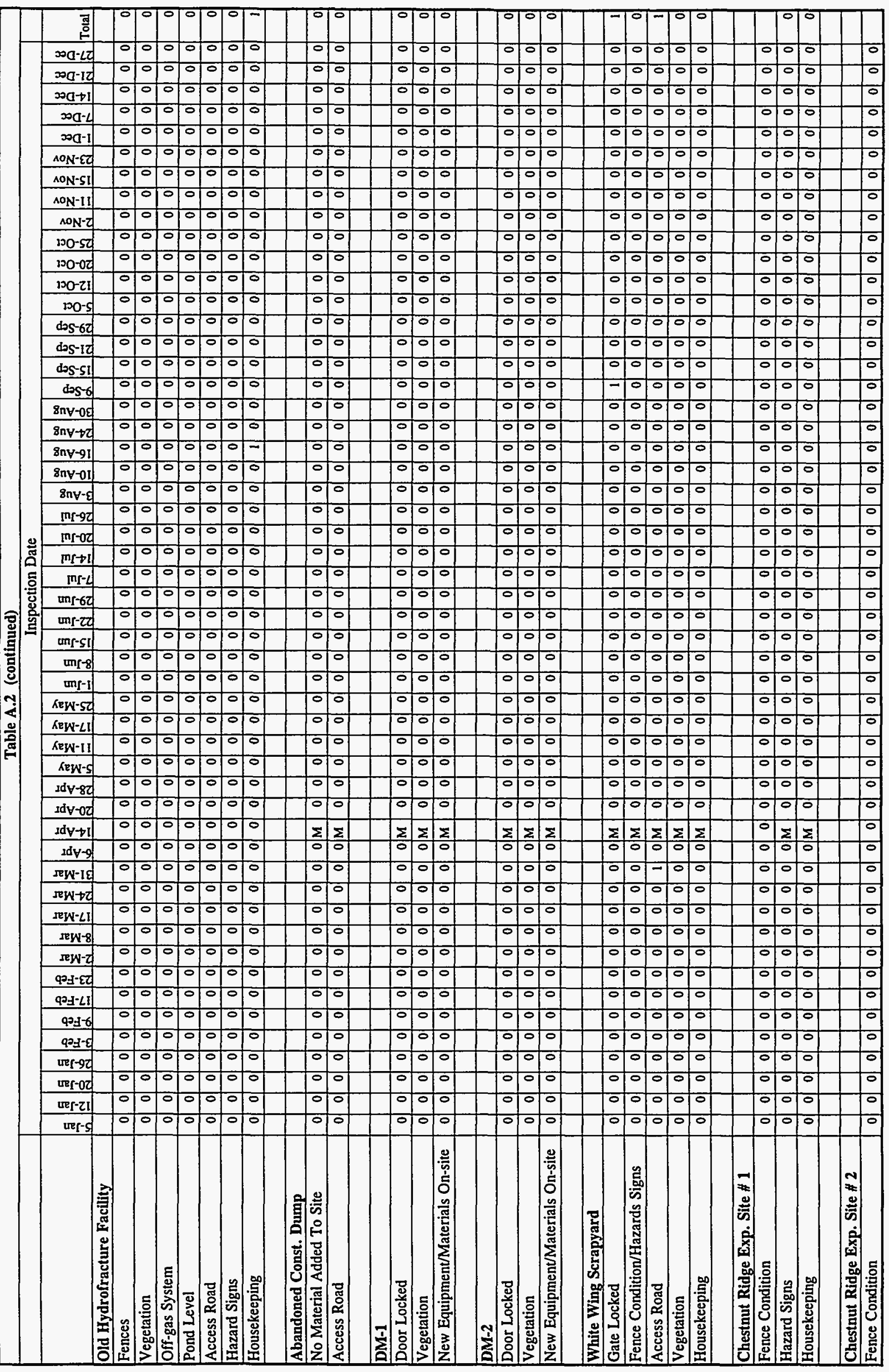




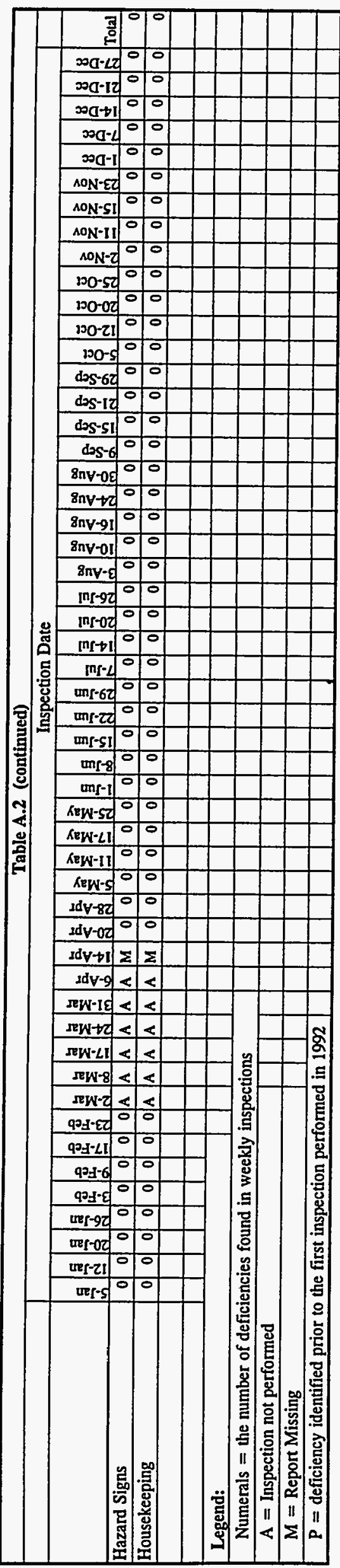


Appendix B

\section{FUNCTIONS AND WASTE CHARACTERISTICS OF THE SITES/FACILITIES \\ MANAGED BY THE ORNL ER S\&M PROGRAM}


Table B.1. WAG 1 site/facilities managed by the S\&M program

\begin{tabular}{|c|c|c|c|}
\hline ID Number & Name & Function & Waste Characteristics \\
\hline 01.01 & Mercury Contaminated Soil - (3503) & Building 3503 was used in the PUREX spent fuel reprocessing program & Major contaminant is liquid mercury \\
\hline 01.02 & Mercury Contaminated Soil - (3592) & $\begin{array}{l}\text { The building around which the soil is located was used in component } \\
\text { development activities for a lithium separation process }\end{array}$ & Major contaminant is liquid mercury \\
\hline 01.03 & Mercury Contaminated Soil - $(4501)$ & $\begin{array}{l}\text { The building around which the soil is located was used in a small pilot } \\
\text { plant supporting the lithium separation process }\end{array}$ & Major contaminant is liquid mercury \\
\hline 01.04 & Mercury Contaminated Soil - (4508) & General research and development activities & Contaminant of concern is liquid mercury \\
\hline $01.05 \mathrm{~A}$ & $\begin{array}{l}\text { Liquid Low-Level (radioactive) Waste LLLW Lines } \\
\text { and Leak/Spill Sites - South of Building } 3020\end{array}$ & $\begin{array}{l}\text { The Main Plant Area LLLW collection system was installed in the } 1940 \text { s } \\
\text { to transfer wastes from various sources to the collection and storage tanks. } \\
\text { The original system was constructed of cast-iron pipe; more recent } \\
\text { additions and modifications are of stainless steel. Many of the reported } \\
\text { leak/spill sites are located near the collection and storage tanks serving the } \\
\text { LLLW lines, others are along the lines themselves, and still others are not } \\
\text { leaks at all but are spills, e.g., from pumping accidents }\end{array}$ & $\begin{array}{l}\text { strontium (Sr)-90, cesium (Cs)-137, cobalt } \\
\text { (Co)-60, plutonium (Pu), uranium (U), } \\
\text { transuranic (TRU) isotopes, nitrate solutions, } \\
\text { acid chlorides }\end{array}$ \\
\hline 01.05B & $\begin{array}{l}\text { LLLW Lines and Leak/Spill Sites - East of the } \\
\text { Building } 3020\end{array}$ & $\begin{array}{l}\text { The Main Plant Area LLLW collection system was installed in the } 1940 \text { s } \\
\text { to transfer wastes from various sources to the collection and storage tanks. } \\
\text { The original system was constructed of cast-iron pipe; more recent } \\
\text { additions and modifications are of stainless steel. Many of the reported } \\
\text { leak/spill sites are located near the collection and storage tanks serving the } \\
\text { LLLW lines, others are along the lines themselves, and still others are not } \\
\text { leaks at all but are spills, e.g., from pumping accidents }\end{array}$ & $\mathrm{Sr}-90, \mathrm{Cs}-137, \mathrm{Co}-60, \mathrm{Pu}, \mathrm{U}, \mathrm{TRU}$ isotopes \\
\hline $01.05 \mathrm{C}$ & $\begin{array}{l}\text { LLLW Lines and Leak/Spill Sites - West of Building } \\
3082\end{array}$ & $\begin{array}{l}\text { The Main Plant Area LLLW collection system was installed in the } 1940 \text { s } \\
\text { to transfer wastes from various sources to the collection and storage tanks. } \\
\text { The original system was constructed of cast-iron pipe; more recent } \\
\text { additions and modifications are of stainless steel. Many of the reported } \\
\text { leak/spill sites are located near the collection and storage tanks serving the } \\
\text { LLLW lines, others are along the lines themselves, and still others are not } \\
\text { leaks at all but are spills, e.g., from pumping accidents }\end{array}$ & Sr-90, Cs-137, Co-60, Pu, U, TRU isotopes \\
\hline $01.05 \mathrm{D}$ & $\begin{array}{l}\text { LLLW Lines and Leak/Spill Sites - North of } \\
\text { Building } 3019\end{array}$ & $\begin{array}{l}\text { The Main Plant Area LLLW collection system was installed in the } 1940 \text { s } \\
\text { to transfer wastes from various sources to the collection and storage tanks. } \\
\text { The original system was constructed of cast-iron pipe; more recent } \\
\text { additions and modifications are of stainless steel. Many of the reported } \\
\text { leak/spill sites are located near the collection and storage tanks serving the } \\
\text { LLLW lines, others are along the lines themselves, and still others are not } \\
\text { leaks at all but are spills, e.g., from pumping accidents }\end{array}$ & Sr-90, Cs-137, Co-60, Pu, U, TRU isotopes \\
\hline
\end{tabular}


Table B.1. (continued)

\begin{tabular}{|c|c|c|c|}
\hline ID Number & Name & Function & Waste Characteristics \\
\hline $01.05 \mathrm{E}$ & $\begin{array}{l}\text { LLLW Lines and Leak/Spill Sites - Southwest Comer } \\
\text { of Building } 3019\end{array}$ & $\begin{array}{l}\text { The Main Plant Area LLLW collection system was installed in the } 1940 \text { s } \\
\text { to transfer wastes from various sources to the collection and storage tanks. } \\
\text { The original system was constructed of cast-iron pipe; more recent } \\
\text { additions and modifications are of stainless steel. Many of the reported } \\
\text { leak/spill sites are located near the collection and storage tanks serving the } \\
\text { LLLW lines, others are along the lines themselves, and still others are not } \\
\text { leaks at all but are spills, e.g., from pumping accidents }\end{array}$ & $\mathrm{Sr}-90, \mathrm{Cs}-137, \mathrm{Co}-60, \mathrm{Pu}, \mathrm{U}, \mathrm{TRU}$ isotopes \\
\hline $01.05 \mathrm{~F}$ & $\begin{array}{l}\text { LLLW Lines and Leak/Spill Sites - Between W-5 } \\
\text { and WC-19 }\end{array}$ & $\begin{array}{l}\text { The Main Plant Area LLLW collection system was installed in the } 1940 \text { s } \\
\text { to transfer wastes from various sources to the collection and storage tanks }\end{array}$ & $\mathrm{Sr}-90, \mathrm{Cs}-137, \mathrm{Co}-60, \mathrm{Pu}, \mathrm{U}, \mathrm{TRU}$ isotopes \\
\hline $01.05 \mathrm{G}$ & $\begin{array}{l}\text { LLLW Lines and Leak/Spill Sites - Underneath } \\
\text { Building } 3047\end{array}$ & $\begin{array}{l}\text { The Main Plant Area LLLW collection system was installed in the } 1940 \text { s } \\
\text { to transfer wastes from various sources to the collection and storage tanks. } \\
\text { The original system was constructed of cast-iron pipe; more recent } \\
\text { additions and modifications are of stainless steel. Many of the reported } \\
\text { leak/spill sites are located near the collection and storage tanks serving the } \\
\text { LLLW lines, others are along the lines themselves, and still others are not } \\
\text { leaks at all but are spills, e.g., from pumping accidents }\end{array}$ & Sr-90, Cs-137, Co-60, Pu, U, TRU isotopes \\
\hline $01.05 \mathrm{H}$ & $\begin{array}{l}\text { LLLW Lines and Leak/Spill Sites - General Isotopes } \\
\text { Area }(3037,3038,3034)\end{array}$ & $\begin{array}{l}\text { The Main Plant Area LLLW collection system was installed in the } 1940 \text { s } \\
\text { to transfer wastes from various sources to the collection and storage tanks. } \\
\text { The original system was constructed of cast-iron pipe; more recent } \\
\text { additions and modifications are of stainless steel. Many of the reported } \\
\text { leak/spill sites are located near the collection and storage tanks serving the } \\
\text { LLLW lines, others are along the lines themselves, and still others are not } \\
\text { leaks at all but are spills, e.g., from pumping accidents }\end{array}$ & $\mathrm{Sr}-90, \mathrm{Cs}-137, \mathrm{Co}-60, \mathrm{Pu}, \mathrm{U}, \mathrm{TRU}$ isotopes \\
\hline 01.051 & $\begin{array}{l}\text { LLLW Lines and Leak/Spill Sites - Building } 3092 \\
\text { Area }\end{array}$ & $\begin{array}{l}\text { The Main Plant Area LLLW collection system was installed in the } 1940 \mathrm{~s} \\
\text { to transfer wastes from various sources to the collection and storage tanks. } \\
\text { The original system was constructed of cast-iron pipe; more recent } \\
\text { additions and modifications are of stainless steel. Many of the reported } \\
\text { leak/spill sites are located near the collection and storage tanks serving the } \\
\text { LLLW lines, others are along the lines themselves, and still others are not } \\
\text { leaks at all but are spills, e.g., from pumping accidents }\end{array}$ & Sr-90, Cs-137, Co-60, Pu, U, TRU isotopes \\
\hline
\end{tabular}

$\infty$ 
Table B.1. (continued)

\begin{tabular}{|c|c|c|c|}
\hline ID Number & Name & Function & Waste Characteristics \\
\hline $01.05 \mathrm{~J}$ & $\begin{array}{l}\text { LLLW Lines and Leak/Spill Sites - Underneath } \\
\text { Building } 3026\end{array}$ & $\begin{array}{l}\text { The Main Plant Area LLLW collection system was installed in the } 1940 \text { s } \\
\text { to transfer wastes from various sources to the collection and storage tanks. } \\
\text { The original system was constructed of cast-iron pipe; more recent } \\
\text { additions and modifications are of stainless steel. Many of the reported } \\
\text { leak/spill sites are located near the collection and storage tanks serving the } \\
\text { LLLW lines, others are along the lines themselves, and still others are not } \\
\text { leaks at all but are spills, e.g., from pumping accidents }\end{array}$ & Sr-90, Cs-137, Co-60, Pu, U, TRU isotopes \\
\hline $01.05 \mathrm{~K}$ & $\begin{array}{l}\text { LLLW Lines and Leak/Spill Sites-Between WC-1 } \\
\text { and W-5 }\end{array}$ & $\begin{array}{l}\text { The Main Plant Area LLLW collection system was installed in the } 1940 \text { s } \\
\text { to transfer wastes from various sources to the collection and storage tanks. } \\
\text { The original system was constructed of cast-iron pipe; more recent } \\
\text { additions and modifications are of stainless steel. Many of the reported } \\
\text { leak/spill sites are located near the collection and storage tanks serving the } \\
\text { LLLW lines, others are along the lines themselves, and still others are not } \\
\text { leaks at all but are spills, e.g., from pumping accidents }\end{array}$ & $\mathrm{Sr}-90, \mathrm{Cs}-137, \mathrm{Co}-60, \mathrm{Pu}, \mathrm{U}, \mathrm{TRU}$ isotopes \\
\hline $01.05 \mathrm{~L}$ & $\begin{array}{l}\text { LLLW Lines and Leak/Spill Sites - Oak Ridge } \\
\text { Research Reactor Water Line (Building 3085) }\end{array}$ & $\begin{array}{l}\text { The water line transports cooling water from the Oak Ridge Research } \\
\text { Reactor to its heat exchangers }\end{array}$ & $\begin{array}{l}\text { Water is the primary coolant for the Oak Ridge } \\
\text { Research Reactor and contains activation } \\
\text { products }\end{array}$ \\
\hline $01.05 \mathrm{M}$ & LLLW Lines and Leak/Spill Sites - Building 3028 & $\begin{array}{l}\text { The Main Plant Area LLLW collection system was installed in the } 1940 \text { s } \\
\text { to transfer wastes from various sources to the collection and storage tanks. } \\
\text { The original system was constructed of cast-iron pipe; more recent } \\
\text { additions and modifications are of stainless steel. Many of the reported } \\
\text { leak/spill sites are located near the collection and storage tanks serving the } \\
\text { LLLW lines, others are along the lines themselves, and still others are not } \\
\text { leaks at all but are spills, e.g., from pumping accidents }\end{array}$ & Sr-90, Cs-137, Co-60, Pu, U, TRU isotopes \\
\hline $01.05 \mathrm{~N}$ & $\begin{array}{l}\text { LLLW Lines and Leak/Spill Sites - East of Building } \\
2531\end{array}$ & $\begin{array}{l}\text { The Main Plant Area LLLW collection system was installed in the } 1940 \text { s } \\
\text { to transfer wastes from various sources to the collection and storage tanks. } \\
\text { The original system was constructed of cast-iron pipe; more recent } \\
\text { additions and modifications are of stainless steel. Many of the reported } \\
\text { leak/spill sites are located near the collection and storage tanks serving the } \\
\text { LLLW lines, others are along the lines themselves, and still others are not } \\
\text { leaks at all but are spills, e.g., from pumping accidents }\end{array}$ & $\mathrm{Sr}-90, \mathrm{Cs}-137, \mathrm{Co}-60, \mathrm{Pu}, \mathrm{U}, \mathrm{TRU}$ isotopes \\
\hline
\end{tabular}


Table B.1. (continued)

\begin{tabular}{|c|c|c|c|}
\hline ID Number & Name & Function & Waste Characteristics \\
\hline 01.050 & $\begin{array}{l}\text { LLLW Lines and Leak/Spill Sites - Underneath } \\
\text { Building } 3515\end{array}$ & $\begin{array}{l}\text { The Main Plant Area LLLW collection system was installed in the } 1940 \text { s } \\
\text { to transfer wastes from various sources to the collection and storage tanks. } \\
\text { The original system was constructed of cast-iron pipe; more recent } \\
\text { additions and modifications are of stainless steel. Many of the reported } \\
\text { leak/spill sites are located near the collection and storage tanks serving the } \\
\text { LLLW lines, others are along the lines themselves, and still others are not } \\
\text { leaks at all but are spills, e.g., from pumping accidents }\end{array}$ & $\begin{array}{l}\text { The area under Building } 3515 \text { is contaminated } \\
\text { as a result of past use as a radioactive chemical } \\
\text { processing plant. Other than that, no } \\
\text { information is available }\end{array}$ \\
\hline $01.05 \mathrm{P}$ & $\begin{array}{l}\text { LLLW Lines and Leak/Spill Sites - Building } 3525 \text { to } \\
\text { a Sump }\end{array}$ & $\begin{array}{l}\text { The Main Plant Area LLLW collection system was installed in the } 1940 \text { s } \\
\text { to transfer wastes from various sources to the collection and storage tanks. } \\
\text { The original system was constructed of cast-iron pipe; more recent } \\
\text { additions and modifications are of stainless steel. Many of the reported } \\
\text { leak/spill sites are located near the collection and storage tanks serving the } \\
\text { LLLW lines, others are along the lines themselves, and still others are not } \\
\text { leaks at all but are spills, e.g., from pumping accidents }\end{array}$ & $\mathrm{Sr}-90, \mathrm{Cs}-137, \mathrm{Co}-60, \mathrm{Pu}, \mathrm{U}, \mathrm{TRU}$ isotopes \\
\hline $01.05 Q$ & $\begin{array}{l}\text { LLLW Lines and Leak/Spill Sites - Underneath } \\
\text { Building } 3550\end{array}$ & $\begin{array}{l}\text { The Main Plant Area LLLW collection system was installed in the } 1940 \text { s } \\
\text { to transfer wastes from various sources to the collection and storage tanks. } \\
\text { The original system was constructed of cast-iron pipe; more recent } \\
\text { additions and modifications are of stainless steel. Many of the reported } \\
\text { leak/spill sites are located near the collection and storage tanks serving the } \\
\text { LLLW lines, others are along the lines themselves, and still others are not } \\
\text { leaks at all but are spills, e.g., from pumping accidents }\end{array}$ & $\mathrm{Sr}-90, \mathrm{Cs}-137, \mathrm{Co}-60, \mathrm{Pu}, \mathrm{U}, \mathrm{TRU}$ isotopes \\
\hline $01.05 \mathrm{R}$ & $\begin{array}{l}\text { LLLW Lines and Leak/Spill Sites - Sewer Near } \\
\text { Building } 3500\end{array}$ & $\begin{array}{l}\text { The Main Plant Area LLLW collection system was installed in the } 1940 \text { s } \\
\text { to transfer wastes from various sources to the collection and storage tanks. } \\
\text { The original system was constructed of cast-iron pipe; more recent } \\
\text { additions and modifications are of stainless steel. Many of the reported } \\
\text { leak/spill sites are located near the collection and storage tanks serving the } \\
\text { LLLW lines, others are along the lines themselves, and still others are not } \\
\text { leaks at all but are spills, e.g., from pumping accidents }\end{array}$ & $\mathrm{Sr}-90, \mathrm{Cs}-137, \mathrm{Co}-60, \mathrm{Pu}, \mathrm{U}, \mathrm{TRU}$ isotopes \\
\hline $01.05 \mathrm{~S}$ & $\begin{array}{l}\text { LLLW Lines and Leak/Spill Sites - Abandoned Line } \\
\text { Central Avenue }\end{array}$ & $\begin{array}{l}\text { The Main Plant Area LLLW collection system was installed in the } 1940 \text { s } \\
\text { to transfer wastes from various sources to the collection and storage tanks. } \\
\text { The original system was constructed of cast-iron pipe; more recent } \\
\text { additions and modifications are of stainless steel. Many of the reported } \\
\text { leak/spill sites are located near the collection and storage tanks serving the } \\
\text { LLLW lines, others are along the lines themselves, and still others are not } \\
\text { leaks at all but are spills, e.g., from pumping accidents }\end{array}$ & Sr-90, Cs-137, Co-60, Pu, U, TRU isotopes \\
\hline
\end{tabular}


Table B.1. (continued)

\begin{tabular}{|c|c|c|c|}
\hline ID Number & Name & Function & Waste Characteristics \\
\hline $01.05 \mathrm{~T}$ & $\begin{array}{l}\text { LLLW Lines and Leak/Spill Sites - Building } 4508 \text {, } \\
\text { North }\end{array}$ & $\begin{array}{l}\text { The Main Plant Area LLLW collection system was installed in the } 1940 \text { s } \\
\text { to transfer wastes from various sources to the collection and storage tanks. } \\
\text { The original system was constructed of cast-iron pipe; more recent } \\
\text { additions and modifications are of stainless steel. Many of the reported } \\
\text { leak/spill sites are located near the collection and storage tanks serving the } \\
\text { LLLW lines, others are along the lines themselves, and still others are not } \\
\text { leaks at all but are spills, e.g., from pumping accidents }\end{array}$ & Sr-90, Cs-137, Co-60, Pu, U, TRU isotopes \\
\hline $01.05 \mathrm{U}$ & $\begin{array}{l}\text { LLLW Lines and Leak/Spill Sites - Building 3518, } \\
\text { West }\end{array}$ & $\begin{array}{l}\text { The PWTP treats the low-level liquid wastes termed process waste } \\
\text { (normally does not contain radioactivity but could be contaminated as the } \\
\text { result of equipment failure or human error) }\end{array}$ & Sr-90, Cs-137 \\
\hline $01.05 \mathrm{~V}$ & $\begin{array}{l}\text { LLLW Lines and Leak/Spill Sites - Northwest of } \\
\text { SWSA } 1\end{array}$ & $\begin{array}{l}\text { The LLLW system at ORNL was designed to collect radioactive waste } \\
\text { solutions from the various sources at the Laboratory. Virtually all of the } \\
\text { buildings within the Laboratory that were involved in radionuclide } \\
\text { operations were served by this system }\end{array}$ & Sr-90, Cs-137, Co-60, Pu, U, TRU isotopes \\
\hline $01.05 \mathrm{~W}$ & $\begin{array}{l}\text { LLLW Lines and Leak/Spill Sites - Building 3503, } \\
\text { Ground Contamination }\end{array}$ & $\begin{array}{l}\text { The Main Plant Area LLLW collection system was installed in the } 1940 \text { s } \\
\text { to transfer wastes from various sources to the collection and storage tanks. } \\
\text { The original system was constructed of cast-iron pipe; more recent } \\
\text { additions and modifications are of stainless steel. Many of the reported } \\
\text { leak/spill sites are located near the collection and storage tanks serving the } \\
\text { LLLW lines, others are along the lines themselves, and still others are not } \\
\text { leaks at all but are spills, e.g., from pumping accidents }\end{array}$ & Sr-90, Cs-137, Co-60, Pu, U, TRU isotopes \\
\hline 01.06 & $\begin{array}{l}\text { Contaminated Surfaces and Soil from } 1959 \text { Explosion } \\
\text { in } 3019 \text { Cell }\end{array}$ & Building 3019 houses the Radiochemical Processing Plant (RPP) & Pu-239 \\
\hline 01.07 & Contamination at Base of 3019 Stack & Data unavailable & $\begin{array}{l}\text { Elevated levels of gross alpha and gross beta, } \\
\mathrm{Pu} \text {, americium }(\mathrm{Am}) \text {, curium }(\mathrm{Cm}), \mathrm{Cs}, \mathrm{Co}\end{array}$ \\
\hline 01.08 & $\begin{array}{l}\text { Graphite Reactor Storage Canal Contaminated Soil } \\
(3001 / 3019)\end{array}$ & $\begin{array}{l}\text { The Oak Ridge Graphite Reactor fuel storage canal connected the fuel } \\
\text { discharge pit to the adjoining chemical-processing building ( } 3019) \text {. It is } \\
\text { currently used for storage of radioisotopes but was originally used for } \\
\text { storage and handling of irradiated fuel and radioisotope targets }\end{array}$ & $\begin{array}{l}\text { Co-60, Sr-90, Pu-239, Pu-238, Am-241, } \\
\text { Cm-244 }\end{array}$ \\
\hline 01.09 & $\begin{array}{l}\text { Oak Ridge Research Reactor Decay Tank Rupture } \\
\text { Site - (3087) }\end{array}$ & The tank contains water coolant & $\begin{array}{l}\text { Isotopes present in the primary coolant water } \\
\text { include sodium (Na)-24, Sr-90, iodine (l)-131, } \\
\text { ruthenium (Ru)-106, Cs-137 }\end{array}$ \\
\hline
\end{tabular}


Table B.1. (continued)

\begin{tabular}{|c|c|c|c|}
\hline ID Number & Name & Function & Waste Characteristics \\
\hline 01.11 & Decommissioned Waste Holding Basin - (3512) & $\begin{array}{l}\text { The pond was dug up and back-filled with gravel during construction of } \\
\text { the Process Waste Water Treatment Plant (3544). Used as a retention } \\
\text { pond for storage tank drainage from } 1944 \text { to 1950, it is presumed to have } \\
\text { handled hazardous substances }\end{array}$ & $\begin{array}{l}\text { Information concerning waste characteristics } \\
\text { could not be found. During the late } 1940 \text { s, } \\
\text { isobutyl methyl ketone was discharged to the } \\
\text { pond }\end{array}$ \\
\hline 01.12 & Waste Holding Basin - (3513) & $\begin{array}{l}\text { The impoundment was constructed to act as a settling basin for wastes } \\
\text { prior to their discharge into White Oak Creek (WOC). It was in operation } \\
\text { until } 1976 \text { when a new PWTP began operation }\end{array}$ & $\begin{array}{l}\text { Cs-137, Sr-90, Co-60, europium (Eu)-154, Pu- } \\
\text { 238, Pu-239, Am-241, Cm-244, Mercury }\end{array}$ \\
\hline 01.13 & Equalization Basin - (3524) & $\begin{array}{l}\text { Process wastes from the ORNL building complexes were delivered to the } \\
\text { Equalization Basin prior to discharge to the process waste treatment } \\
\text { facility (Building 3544). Basin } 3524 \text { normally received process wastes } \\
\text { from the Bethel Valley ORNL facility, but on occasion some waste from } \\
\text { the Melton Valley facilities was received }\end{array}$ & $\begin{array}{l}\text { Cs-137, Sr-90, thorium (Th), U, TRU, benzene, } \\
\text { chloroform, methylene chloride }\end{array}$ \\
\hline 01.14 & Process Waste Pond - (3539) & $\begin{array}{l}\text { The two } 190 \text { Process Waste ponds (also see } 01.15 \text { ) are paired surge } \\
\text { basins, designed to receive process waste streams from the Building } 4500 \\
\text { complex. Waste streams from Building } 4500 \text { are split into the basins and } \\
\text { monitored for radionuclide content before discharge to WoC or to the } \\
\text { Equalization Basin (3524) and the process waste treatment system } \\
\text { (Building } 3544 \text { ). The basins are operated in such a manner that when one } \\
\text { pond is filling the other is empty or in the process of being emptied }\end{array}$ & $\begin{array}{l}\text { Metal, pesticide, herbicide, methylene chloride, } \\
\text { 1,2-transdichloroethylene }\end{array}$ \\
\hline 01.15 & Process Waste Pond - (3540) & $\begin{array}{l}\text { The two } 190 \text { Process Waste ponds (also see } 01.15 \text { ) are paired surge } \\
\text { basins, designed to receive process waste streams from the Building } 4500 \\
\text { complex. Waste streams from Building } 4500 \text { are split into the basins and } \\
\text { monitored for radionuclide content before discharge to woC or to the } \\
\text { Equalization Basin (3524) and the process waste treatment system } \\
\text { (Building } 3544 \text { ). The basins are operated in such a manner that when one } \\
\text { pond is filling the other is empty or in the process of being emptied }\end{array}$ & $\begin{array}{l}\text { Metal, pesticide, herbicide, methylene chloride, } \\
\text { 1,2-transdichloroethylene }\end{array}$ \\
\hline 01.19 & Low Intensity Test Reactor (LITR) Pond - (3085W) & $\begin{array}{l}\text { These ponds were used to retain process waste water before its release } \\
\text { into the Fifth Street branch of WOC. In 1964, the ponds were filled with } \\
\text { clay and earth and covered with grass }\end{array}$ & $\begin{array}{l}\text { Very little information is available. Principal } \\
\text { contamination was probably Na-24 }\end{array}$ \\
\hline 01.20 & $\begin{array}{l}3517 \text { Filter Pit (Fission Product Development } \\
\text { Laboratory [FPDL] - (3517) }\end{array}$ & The unit was designed to filter building air exhaust from the FPDL & $\begin{array}{l}\text { Present levels of radiation at the filters measure } \\
\text { approximately } 200 \mathrm{R} / \mathrm{h} \text {. The main } \\
\text { radionuclides are Cs-137 and Sr-90 }\end{array}$ \\
\hline
\end{tabular}


Table B.1. (continued)

\begin{tabular}{|c|c|c|c|}
\hline ID Number & Name & Function & Waste Characteristics \\
\hline 01.21 & FPDL LLLW Transfer Line & $\begin{array}{l}\text { The line was designed to transfer LLLW from the FPDL to collection } \\
\text { tanks at the South Tank Farm (area 3507) }\end{array}$ & $\begin{array}{l}\text { No inventory of radiological wastes exists. The } \\
\text { line is thought to be contaminated with Cs-137 } \\
\text { and Sr-90 }\end{array}$ \\
\hline $01.23 \mathrm{~A}$ & Inactive LLLW Collection/Storage Tank W-I & The tank was designed to hold waste from the $3019 \mathrm{RPP}$ & Sr-90, Cs-137, Eu-152, TRU, Pu-238 \\
\hline $01.23 \mathrm{~B}$ & Inactive LLLW Collection/Storage Tank W-2 & This tank was designed to hold the overflow from tank W-1 & Sr-90, Cs-137, Eu-152, TRU, Pu-238 \\
\hline $01.24 \mathrm{~A}$ & Inactive LLLW Collection/Storage Tank W-3 & $\begin{array}{l}\text { The tank was designed to hold metal waste from Building } 3019 \text {. Tank } \\
\text { W-3 received Pu waste }\end{array}$ & $\begin{array}{l}\text { Cs-137, Sr-90, TRU, Pu-238, Pu-239, Am-241, } \\
\text { Cm-244, U-233, U-238 }\end{array}$ \\
\hline $01.24 B$ & Inactive LLLW Collection/Storage Tank W-4 & $\begin{array}{l}\text { The tank was designed to hold metal waste from Building 3019. Tank } \\
\text { W-4 received Pu waste }\end{array}$ & $\begin{array}{l}\text { Cs-137, Sr-90, U-238, U-233, Pu-238, Pu-239, } \\
\text { Am-241, Cm-244, U-235, TRU }\end{array}$ \\
\hline $01.25 \mathrm{~A}$ & Inactive LLLW Collection/Storage Tank W-13 & $\begin{array}{l}\text { Tank W-13 collected waste from the Chemistry Division (CD) Hot } \\
\text { Laboratory Group }\end{array}$ & Sr-90, Cs-137, TRU \\
\hline 01.25B & Inactive LLLW Collection/Storage Tank W-14 & Tank W-14 collected wastes from the Operations Division & St-90, Cs-137, TRU \\
\hline $01.25 \mathrm{C}$ & Inactive LLLW Collection/Storage Tank W-15 & Tank W-15 collected wastes from the Operations Division & No inventory estimate available for Tank W-15 \\
\hline $01.26 \mathrm{~A}$ & Inactive LLLW Collection/Storage Tank W-5 & $\begin{array}{l}\text { The tank was designed to store wastes from various ORNL projects and } \\
\text { programs }\end{array}$ & Sr-90, Cs-137, Th-232, U-238, TRU \\
\hline $01.26 \mathrm{~B}$ & Inactive LLLW Collection/Storage Tank W-6 & $\begin{array}{l}\text { The tank was designed to store wastes from various ORNL projects and } \\
\text { programs }\end{array}$ & Sr-90, Cs-137, Th-232, U-238, TRU \\
\hline $01.26 \mathrm{C}$ & Inactive LLLW Collection/Storage Tank W-7 & $\begin{array}{l}\text { The tank was designed to store wastes from various ORNL projects and } \\
\text { programs }\end{array}$ & Sr-90, Cs-137, Th-232, U-238, TRU \\
\hline $01.26 \mathrm{D}$ & Inactive LLLW Collection/Storage Tank W-8 & $\begin{array}{l}\text { The tank was designed to store wastes from various ORNL projects and } \\
\text { programs }\end{array}$ & Sr-90, Cs-137, Th-232, U-238, TRU \\
\hline $01.26 \mathrm{E}$ & Inactive LLLW Collection/Storage Tank W-9 & $\begin{array}{l}\text { The tank was designed to store wastes from various ORNL projects and } \\
\text { programs }\end{array}$ & Sr-90, Cs-137, Th-232, U-238, TRU \\
\hline $01.26 \mathrm{~F}$ & Inactive LLLW Collection/Storage Tank W-10 & $\begin{array}{l}\text { The tank was designed to store wastes from various ORNL projects and } \\
\text { programs }\end{array}$ & Sr-90, Cs-137, Th-232, U-238, TRU \\
\hline 01.27 & Inactive LLLW Collection/Storage Tank W-11 & $\begin{array}{l}\text { The tank was designed to serve in waste collection and monitoring for } \\
\text { research laboratories in Building } 3550\end{array}$ & $\begin{array}{l}\text { Cs-137, Sr-90, PU-238, TRU, transferable beta- } \\
\text { gamma and alpha activities }\end{array}$ \\
\hline
\end{tabular}


Table B.1. (continued)

\begin{tabular}{|c|c|c|c|}
\hline ID Number & Name & Function & Waste Characteristics \\
\hline 01.28 & Inactive LLLW Collection/Storage Tank W-1A & $\begin{array}{l}\text { Tank W-1 A collected wastes from the high radiation level analytical } \\
\text { facilities of Buildings } 2026,3019-\mathrm{B} \text {, and the RPP (3019) }\end{array}$ & $\begin{array}{l}\text { Major contaminants are Sr-90, Cs-137, U-233 } \\
\text { and TRU. Radionuclide inventory is unknown }\end{array}$ \\
\hline 01.29 & Inactive LLLW Collection/Storage Tank WC-1 & $\begin{array}{l}\text { The tank was used for the collection and monitoring of process liquid } \\
\text { waste from isotope production and development laboratories (Buildings } \\
3038,3029,3030,3031,3032,3033 \text {, and 3047). The tank also collected } \\
\text { waste from the Building } 3110 \text { filter, } 3039 \text { stack, and } 3092 \text { scrubber }\end{array}$ & Sr-90, Cs-137, TRU, Co- 60 \\
\hline $01.30 \mathrm{~A}$ & Inactive LLLW Collection/Storage Tank WC-15 & $\begin{array}{l}\text { Tank was designed to receive waste from research laboratories in } \\
\text { Building } 4500\end{array}$ & Cs-137, Sr-90, TRU \\
\hline $01.30 \mathrm{~B}$ & Inactive LLLW Collection/Storage Tank WC-17 & $\begin{array}{l}\text { Tank was designed to receive waste from research laboratories in } \\
\text { Building } 4500\end{array}$ & $\begin{array}{l}\text { Major radionuclides are Cs-137, Sr-90, TRU. } \\
\text { The tank is full of oil and water }\end{array}$ \\
\hline $01.31 \mathrm{~A}$ & Inactive LLLW Collection/Storage Tank TH-1 & Tank received waste from the thorium pilot plant project in Building 3503 & Cs-137, Co-60, Sr-90, TRU \\
\hline $01.31 \mathrm{~B}$ & Inactive LLLW Collection/Storage Tank TH-2 & Tank received waste from the thorium pilot plant project in Building 3503 & alpha, beta-gamma \\
\hline $01.31 \mathrm{C}$ & Inactive LLLW Collection/Storage Tank TH-3 & Tank received waste from the thorium pilot plant project in Building 3503 & Cs-137, Co-60, Sr-90, TRU \\
\hline 01.32 & Inactive LLLW Collection/Storage Tank TH-4 & $\begin{array}{l}\text { Tank was placed in service to receive waste from the irradiated thorium } \\
\text { and uranium pilot plant development projects }\end{array}$ & $\begin{array}{l}\text { Presently, the tank is filled with alkaline } \\
\text { thorium and } U \text { sludge. Most of the radiation is } \\
\text { due to Cs-137 and small amounts of TRU. } \\
\text { Major rad. inventory is Sr-90, Cs-137, and TRU }\end{array}$ \\
\hline 01.36 & Inactive LLLW Collection Tank WC-4 & $\begin{array}{l}\text { The tank receives waste from Building } 3026 \text { and discharges to Valve Box } \\
\text { No. } 2 \text { at the South Tank Farm }\end{array}$ & $\begin{array}{l}\text { The major nuclides of concern are } \mathrm{Sr}-90, \mathrm{Cs}- \\
137, \mathrm{Co}-60 \text {, and TRU. Some tanks also contain } \\
\text { small amounts of } \mathrm{U} \text { and Pu isotopes }\end{array}$ \\
\hline $01.37 \mathrm{~A}$ & Inactive LLLW Collection Tank WC-5 & $\begin{array}{l}\text { The tank receives waste from Building } 3503 \text { and discharges to Valve Box } \\
\text { No. } 2 \text { at the South Tank Farm }\end{array}$ & $\begin{array}{l}\text { The major nuclides of concern are Sr-90, Cs- } \\
137, \text { Co-60, and TRU. Some tanks also contain } \\
\text { small amounts of } U \text { and Pu isotopes }\end{array}$ \\
\hline $01.37 \mathrm{~B}$ & Inactive LLLW Collection Tank WC-6 & $\begin{array}{l}\text { The tank receives waste from Buildings } 3508,3541 \text {, and } 3592 \text {. It } \\
\text { discharges to Valve Box No. } 2 \text { at the South Tank Farm }\end{array}$ & $\begin{array}{l}\text { The major nuclides of concern are Sr-90, Cs- } \\
137, \text { Co-60, and TRU. Some tanks also contain } \\
\text { small amounts of } U \text { and } \mathrm{Pu} \text { isotopes }\end{array}$ \\
\hline $01.37 \mathrm{C}$ & Inactive LLLW Collection Tank WC-8 & $\begin{array}{l}\text { The tank receives waste from Building } 3503 \text { and discharges to Valve Box } \\
\text { No. } 2 \text { at the South Tank Farm }\end{array}$ & $\begin{array}{l}\text { The major nuclides of concern are Sr-90, Cs- } \\
137, \text { Co-60, and TRU. Some tanks also contain } \\
\text { small amounts of } U \text { and Pu isotopes }\end{array}$ \\
\hline
\end{tabular}


Table B.1. (continued)

\begin{tabular}{|c|c|c|c|}
\hline ID Number & Name & Function & Waste Characteristics \\
\hline 01.39B & Inactive LLLW Collection Tank WC-11 & $\begin{array}{l}\text { The tank receives waste from Buildings } 4500 \mathrm{~N} \text { Wing } 1,4505,4507 \text {, and } \\
\text { 4556. It discharges to Valve Box No. } 1 \text { at the South Tank Farm }\end{array}$ & $\begin{array}{l}\text { The major nuclides of concern are Sr-90, Cs- } \\
137, \mathrm{Co}-60 \text {, and TRU. Some tanks also contain } \\
\text { small amounts of } U \text { and } \mathrm{Pu} \text { isotopes }\end{array}$ \\
\hline $01.39 \mathrm{C}$ & Inactive LLLW Collection Tank WC-12 & $\begin{array}{l}\text { The tank receives waste from Buildings } 4505 \text { and } 4507 \text {. It discharges to } \\
\text { Valve Box No. } 1 \text { at the South Tank Farm }\end{array}$ & $\begin{array}{l}\text { The major nuclides of concern are Sr-90, Cs- } \\
137, \text { Co-60, and TRU. Some tanks also contain } \\
\text { small amounts of } U \text { and Pu isotopes }\end{array}$ \\
\hline 01.39D & Inactive LLLW Collection Tank WC-13 & $\begin{array}{l}\text { The tank receives waste from Buildings } 4500 \text { S, } 4500 \mathrm{~N}, 4501 \text {, and } 4508 \text {. } \\
\text { it discharges to Valve Box No. } 1 \text { at the South Tank Farm }\end{array}$ & $\begin{array}{l}\text { The major nuclides of concern are Sr-90, Cs- } \\
137, \mathrm{Co}-60 \text {, and TRU. Some tanks also contain } \\
\text { small amounts of } \mathrm{U} \text { and } \mathrm{Pu} \text { isotopes }\end{array}$ \\
\hline $01.39 \mathrm{E}$ & Inactive LLLW Collection Tank WC-14 & $\begin{array}{l}\text { The tank receives waste from Building 4501. It discharges to Valve Box } \\
\text { No. } 1 \text { at the South Tank Farm }\end{array}$ & $\begin{array}{l}\text { The major nuclides of concern are Sr-90, Cs- } \\
137 \text {, Co-60, and TRU. Some tanks also contain } \\
\text { small amounts of } U \text { and Pu isotopes }\end{array}$ \\
\hline $01.42 \mathrm{~B}$ & Inactive LLLW Collection Tank W-17 & This tank collects LLLW from hot cells in Building 3026 & $\begin{array}{l}\text { The major nuclides of concern are Sr-90, Cs- } \\
137, \text { Co-60, and TRU. Some tanks also contain } \\
\text { small amounts of } U \text { and Pu isotopes }\end{array}$ \\
\hline $01.42 \mathrm{C}$ & Inactive LLLW Collection Tank W-18 & $\begin{array}{l}\text { This tank collects LLLW from hot cells in Building } 3026 \text { and liquids } \\
\text { from the } 3500 \text { area cell ventilation duct }\end{array}$ & $\begin{array}{l}\text { The major nuclides of concem are Sr-90, Cs- } \\
137, \text { Co-60, and TRU. Some tanks also contain } \\
\text { small amounts of } U \text { and } \mathrm{Pu} \text { isotopes }\end{array}$ \\
\hline 01.46 & SWSA 1 - (2624) & SWSA 1 was the first area used for burial of low-level solid wastes & $\begin{array}{l}\text { The burial ground is contaminated with } \\
\text { unknown radionuclides and unidentified } \\
\text { chemical constituents. Only a small amount of } \\
\text { solid radioactive waste was buried in SWSA } 1\end{array}$ \\
\hline 01.47 & SWSA 2 - (4003) & $\begin{array}{l}\text { The area was the second used to dispose of solid waste contaminated with } \\
\text { beta or gamma activity, liquid waste contaminated with } \mathrm{Pu} \text { in stainless } \\
\text { steel drums, and alpha-contaminated material from off-site }\end{array}$ & $\begin{array}{l}\text { The burial site is reported to contain no waste. } \\
\text { The burial waste and contaminated soil were } \\
\text { moved to another site (SWSA 3) some time } \\
\text { after the site was closed in } 1946\end{array}$ \\
\hline $01.56 \mathrm{~A}$ & Inactive LLLW Collection Tank W-19 & $\begin{array}{l}\text { This tank [and W-20 (SWMU 01.56B)] were installed for the purpose of } \\
\text { collecting LLLW solutions from Building } 3505 \text {. After closure of the } \\
\text { Metal Recovery Facility (MRF) in 1960, the tanks were used for a period } \\
\text { of } 1-2 \text { years by the FPDL for LLLW collection }\end{array}$ & $\begin{array}{l}\text { Sr-90, Cs-137, Pu-238, Pu-239, Pu-240, Ce- } \\
\text { 144, promethium (Pm)-147 }\end{array}$ \\
\hline
\end{tabular}


Table B.1. (continued)

\begin{tabular}{|c|c|c|c|}
\hline ID Number & Name & Function & Waste Characteristics \\
\hline $01.56 \mathrm{~B}$ & Inactive LLLW Collection Tank W-20 & $\begin{array}{l}\text { This tank [and W-19 (SWMU 01.56A)] were installed for the purpose of } \\
\text { collecting LLLW solutions from Building } 3505 \text {. After closure of the } \\
\text { MRF in 1960, the tanks were used for a period of } 1-2 \text { years by the FPDL } \\
\text { for LLLW collection }\end{array}$ & $\begin{array}{l}\text { Sr-90, Cs-137, Pu-238, Pu-239, Pu-240, Ce- } \\
\text { 144, Pm-147 }\end{array}$ \\
\hline 01.58 & $\begin{array}{l}\text { Former Waste Pile Area (South of Nonradiological } \\
\text { Wastewater Treatment Plant [NRWTP]) }\end{array}$ & $\begin{array}{l}\text { Apparently used for disposal of waste from construction operations. May } \\
\text { be an extension of solid waste management unit (SWMU) } 01.57\end{array}$ & Construction trash and debris \\
\hline 01.62 & Waste Evaporator Facility (3506) & $\begin{array}{l}\text { The Waste Evaporator Facility was used for concentration and volume } \\
\text { reduction of the liquid waste prior to its final disposal in excavated pits } \\
\text { and trenches }\end{array}$ & $\begin{array}{l}\text { Sr-90, Cs-137, Ru-106, Co- } 60, \mathrm{Pu}, \mathrm{U}, \mathrm{TRU} \\
\text { isotopes, nitrate solutions, acid chlorides }\end{array}$ \\
\hline 01.63 & Transfer Canal and Dissolver Pit (3505) & $\begin{array}{l}\text { Used to handle fuel elements (slugs) prior to dissolving the fuel element } \\
\text { cladding for } U \text { recovery. Water was used as shielding }\end{array}$ & $\begin{array}{l}\text { Canal wall and water probably contaminated } \\
\text { with } \mathrm{Sr}-90, \mathrm{Cs}-137, \mathrm{Co}-60 \text {, and } \mathrm{U} \text { and } \mathrm{Pu} \\
\text { isotopes. }\end{array}$ \\
\hline $01.64 \mathrm{C}$ & Inactive LLLW Collection Tank S-424 & $\begin{array}{l}\text { Tank S- } 424 \text { is designed to collect radioactive low-level waste prior to } \\
\text { transfer to the LLLW treatment plant }\end{array}$ & $\begin{array}{l}\text { LLLW resulting from fission product } \\
\text { separations in Building } 3517\end{array}$ \\
\hline 01.66 & Inactive LLLW Collection Tank W-1I & $\begin{array}{l}\text { Collects LLLW from hot cell in Building } 3028 \text { and discharge from tank is } \\
\text { pumped to tank WC-10 }\end{array}$ & No reported chemical or radionuclide analyses \\
\hline $01.67 \mathrm{~A}$ & Inactive LLLW Collection Tank 4501-C & $\begin{array}{l}\text { Used to Collect LLLW from cells and laboratories in the High Level } \\
\text { Radiochemical Laboratory ( } 4501 \text { ). Tank } 4501-C \text { is not currently in use } \\
\text { and has been disconnected from ancillary piping }\end{array}$ & $\begin{array}{l}\text { No analyses have been reported for tank } \\
\text { contents }\end{array}$ \\
\hline $01.67 \mathrm{~B}$ & Inactive LLLW Collection Tank 4501-D & $\begin{array}{l}\text { Used to Collect LLLW from cells and laboratories in the High Level } \\
\text { Radiochemical Laboratory ( } 4501 \text { ). Tank } 4501-D \text { is not currently in use } \\
\text { and has been disconnected from ancillary piping }\end{array}$ & $\begin{array}{l}\text { No analyses have been reported for tank } \\
\text { contents }\end{array}$ \\
\hline $01.67 \mathrm{C}$ & Inactive LLLW Collection Tank 4501-P & $\begin{array}{l}\text { Tank 4501-P was installed in } 1955 \text { to serve the aqueous Homogeneous } \\
\text { Reactor Project (HRP) as a holding tank for Pu solutions prior to } \\
\text { treatment in the LLLW system. In 1963, the tank was used with the } \\
\text { Thorium Utilization Project as a holding tank for thorium solutions. The } \\
\text { tank is inactive, it has been out of service for many years. All of the } \\
\text { entries to the tank are sealed or valved }\end{array}$ & $\begin{array}{l}\text { The tank contains an estimated } 7 \text { gallons of } \\
\text { liquid. A rad survey indicates alpha activity. } \\
\text { No analyses of hazardous constituents are } \\
\text { available }\end{array}$ \\
\hline 01.68 & Inactive Filter House Seal Tank 3002-A & $\begin{array}{l}\text { Tank 3002-A collects drainage from the } 3002 \text { filter house; effluent is } \\
\text { transferred to tank WC-19. This tank is no longer in use }\end{array}$ & $\begin{array}{l}\text { No analyses have been reported for hazardous } \\
\text { waste components or radionuclides }\end{array}$ \\
\hline
\end{tabular}

$\infty$ 
Table B.1. (continued)

\begin{tabular}{|c|c|c|c|}
\hline ID Number & Name & Function & Waste Characteristics \\
\hline 01.71 & Inactive LLLW Collection Tank H-209 & $\begin{array}{l}\text { Used to collect condensate and contaminated process waste from the floor } \\
\text { drains in Building } 3517\end{array}$ & Unknown \\
\hline 01.73 & Inactive LLLW Collection Tank 3001-B & $\begin{array}{l}\text { This tank is thought to have been a hold up tank for the hot lab drains in } \\
\text { Building } 3001 \text {. This hot lab handled mostly irradiated samples, and any } \\
\text { radioactive waste from it has probably decayed to very low levels }\end{array}$ & Unknown \\
\hline 01.74 & Inactive LLLW Collection Tank 3003-A & $\begin{array}{l}\text { Collects waste from floor drains in cells in Building } 3003 \text { (Fan House for } \\
\text { Graphite Reactor), and from the Graphite Reactor Stack }\end{array}$ & Unknown \\
\hline 01.75 & Inactive LLLW Collection Tank 3004-B & $\begin{array}{l}\text { Tank 3004-B is called the Low-Intensity Test Reactor (LITR) Hot Waste } \\
\text { Holdup Tank. It appears that this tank, similar to the other hold-up tanks, } \\
\text { could be emptied to the process water system or the LLLW system, } \\
\text { depending on the contamination level of the water }\end{array}$ & Unknown \\
\hline 01.76 & Inactive LLLW Collection Tank 3013 & $\begin{array}{l}\text { This tank is connected to the drains in Building } 3013 \text {. Building } 3013 \text { was } \\
\text { originally an environmental processing lab that dealt with very low level } \\
\text { contaminated environmental samples. It was later a source storage } \\
\text { building that held sealed sources, which should not have led to } \\
\text { contaminated discharges }\end{array}$ & Unknown \\
\hline 01.78 & Inactive LLLW Collection Tank T-30 & $\begin{array}{l}\text { Collect LLLW from hot cell operations in the High Radiation Level } \\
\text { Chemical Development Laboratory (4507) }\end{array}$ & $\begin{array}{l}\text { LLLW from hot cell operations. Sampling of } \\
\text { liquid contents indicate that liquid phase is not } \\
\text { a Resource Conservation and Recovery Act } \\
\text { (RCRA) waste. No sludge reported in the tank }\end{array}$ \\
\hline 01.79 & 3001 Storage Canal & $\begin{array}{l}\text { The } 3001 \text { Storage Canal connected the fuel discharge pit to the adjoining } \\
\text { chemical-processing building ( } 3019 \text { ). It is currently used for storage of } \\
\text { radioisotopes but was originally used for storage and handling of } \\
\text { irradiated fuel and radioisotope targets }\end{array}$ & $\begin{array}{l}\text { Canal wastes may be contaminated with } \\
\text { radionuclides and RCRA heavy metals released } \\
\text { from ruptured fuel slugs. Activity levels should } \\
\text { be low with Sr-90 and } \mathrm{C} 0-60 \text { as main } \\
\text { constituents }\end{array}$ \\
\hline 01A.01E & $\begin{array}{l}\text { Underground Exhaust Ducts Soil Contamination } \\
3001-3003\end{array}$ & $\begin{array}{l}\text { The underground duct system transmits the Graphite Reactor cooling air } \\
\text { from the reactor }(3001) \text { to the Filter House (3002), the Fan House (3003), } \\
\text { and then to the stack }(3010)\end{array}$ & $\begin{array}{l}\text { Unknown, duct walls are probably } \\
\text { contaminated with fission products. Both alpha } \\
\text { and beta-gamma contamination has been } \\
\text { reported on the duct walls }\end{array}$ \\
\hline $01 A .06$ & Fission Product Pilot Plant (3515) & $\begin{array}{l}\text { From } 1950-1951 \text {, the facility functioned as a hot cell facility. It was then } \\
\text { used to separate curie quantities of various radionuclides from low-level } \\
\text { liquid wastes }\end{array}$ & Specific waste information is not available \\
\hline
\end{tabular}


Table B.1. (continued)

\begin{tabular}{||l|l|c|c||}
\hline \multicolumn{1}{|c|}{ ID Number } & \multicolumn{1}{|c|}{ Name } & \multicolumn{1}{|c|}{ Function } & Waste Characteristics \\
\hline \hline 00.33 & Fission Product Pilot Plant Contaminated Soil & & \\
\hline 00.50 & WAG 1 Groundwater & & \\
\hline 00.51 & WAG 1 WOC Floodplain Soils and Sediments & & \\
\hline
\end{tabular}


Table B.2. WAG 2 site/facilities managed by the S\&M program

\begin{tabular}{|c|c|c|c|}
\hline ID Number & Name & Function & Waste Characteristics \\
\hline 02.01 & White Oak Lake and Embayment (7846) & $\begin{array}{l}\text { The site is a surface impoundment for radioactive and other hazardous } \\
\text { wastes that drain from ORNL via the WOC Watershed. It serves as a } \\
\text { final settling basin for waste released from ORNL operations and waste } \\
\text { storage areas }\end{array}$ & $\begin{array}{l}\text { Sr-90, Cs-137, Th, U, TRU, cadmium (Cd), } \\
\mathrm{Cr}, \mathrm{Co}-60 \text {, histone }(\mathrm{H})-3\end{array}$ \\
\hline 02.02 & WOC and Tributaries (0853) & $\begin{array}{l}\text { The creek drains the ORNL installation. Treated sewage and process } \\
\text { wastes are released to the creek after treatment. LLLW after treatment in } \\
\text { the PWTP is also discharged to the creek }\end{array}$ & $\begin{array}{l}\text { Main contaminants are } \mathrm{Sr}-90, \mathrm{Co}-60, \mathrm{Cs}-137 \text {, } \\
\mathrm{H}-3 \text {, and metals (mercury }(\mathrm{Hg}) \text {, zinc }(\mathrm{Zn}) \text {, and } \\
\mathrm{Cr} \text { ). Hazardous Chemicals, including PCBs, } \\
\text { may be present in the stream sediments. } \\
\text { Pu- } 239 \text { also detected }\end{array}$ \\
\hline 00.53 & WAG 2 Groundwater & & \\
\hline
\end{tabular}


Table B.3. WAG 3 site/facilities managed by the S\&M program

\begin{tabular}{||l|l|l|l|}
\hline \multicolumn{1}{|c|}{ ID Number } & \multicolumn{1}{|c|}{ Name } & \multicolumn{1}{c|}{ Function } & Waste Characteristics \\
\hline \hline 03.01 & SWSA 3 (1001) & $\begin{array}{l}\text { The site was used as a landfill for the storage of LLLW. The site was } \\
\text { also used to store scrap metal (See 03.02) }\end{array}$ & $\begin{array}{l}\text { Little is known about the kinds of wastes stored } \\
\text { at this site. Large items were stored } \\
\text { aboveground within the fenced-in area. Alpha } \\
\text { wastes contained in drums were deposited in } \\
\text { concrete-lined trenches and covered with } \\
\text { concrete. Beta-gamma wastes were buried in } \\
\text { unlined trenches and backfilled with soil }\end{array}$ \\
\hline 03.02 & Scrap Metal Area (1562) & $\begin{array}{l}\text { The purpose of the site was to serve as a storage site for contaminated } \\
\text { metal. Most of the scrap has now been buried in other SWSAs (1984), } \\
\text { and the area is posted }\end{array}$ & $\begin{array}{l}\text { Some contaminated tanks and equipment are } \\
\text { still stored aboveground. Tanks may be } \\
\text { contaminated. The amount of material stored is } \\
\text { not reported }\end{array}$ \\
\hline 03.03 & Contractors' Landfill - (1554) & $\begin{array}{l}\text { The purpose of the landfill is disposal of debris from construction sites } \\
\text { and noncontaminated demolition activities. The site is also used as a } \\
\text { disposal area for fly ash from the ORNL steam plant }\end{array}$ & $\begin{array}{l}\text { This facility is now permitted by TDHE. Only } \\
\text { non-contaminated debris and construction } \\
\text { materials are allowed in the landfill. No } \\
\text { hazardous or radioactive wastes are allowed }\end{array}$ \\
\hline
\end{tabular}


Table B.4. WAG 4 site/facilities managed by the S\&M program

\begin{tabular}{|c|c|c|c|}
\hline ID Number & Name & Function & Waste Characteristics \\
\hline 04.01 & Low-Level Waste Line North of Lagoon Road (7800) & $\begin{array}{l}\text { The first 1.5-mile (2.4-km) section of the waste transfer line is 2-in.-diam } \\
\text { (5-cm-diam) cast-iron pipe installed in June } 1954 \text { to transfer LLLW from } \\
\text { the Bethel Valley waste storage tanks to Waste Pit } 2 \text {. Carbon steel } \\
\text { extensions to Trench } 5 \text { (1960), Trench } 6 \text { (1961), and finally to Trench } 7 \\
\text { (1962) completed the transfer line to the waste pit area. In 1966, a cast- } \\
\text { iron line was installed from Trench } 7 \text { to the Old Hydrofracture Facility } \\
\text { (OHF) (1.5 miles). This line was replaced in } 1971 \text { by a stainless stecl } \\
\text { line installed next to the old cast-iron line. This line was taken out of } \\
\text { service in } 1975\end{array}$ & $\begin{array}{l}\text { Wastes handled in the transfer system were } \\
\text { routinely generated laboratory LLLW. Major } \\
\text { radionuclides were Sr-90, Cs-137, Ru-106, Co- } \\
60 \text { and various rare earths. Some } \mathrm{Pu}, \mathrm{U} \text {, and } \\
\text { TRU isotopes were also present in the waste } \\
\text { streams from certain sources }\end{array}$ \\
\hline 04.03 & SWSA 4 (7800) & $\begin{array}{l}\text { The unit was a solid waste landfill designed to contain radioactive solid } \\
\text { waste. For a period of time, the landfill was designated as the Southem } \\
\text { Regional Burial Ground by the Atomic Energy Commission (AEC) and } \\
\text { received wastes from nuclear installation in the eastern United States }\end{array}$ & $\begin{array}{l}\text { Little information exists to characterize the } \\
\text { type, concentration, or quantity of radionuclides } \\
\text { placed in SWSA 4. Radioactive elements } \\
\text { include Sr-90, Cs-137, Co-60, polonium (Po)- } \\
210, \mathrm{H}-3 \text {, antimony (Sb)-125, and Pu-239 }\end{array}$ \\
\hline
\end{tabular}


Table B.5. WAG 5 site/facilities managed by the S\&M program

\begin{tabular}{|c|c|c|c|}
\hline ID Number & Name & Function & Waste Characteristics \\
\hline $05.01 \mathrm{~A}$ & LLLW Lines and Leak Site - OHF, Release of Grout & $\begin{array}{l}\text { The well was being drilled as a part of research related to the grout sheets } \\
\text { produced at the OHF }\end{array}$ & The waste is water containing $\mathrm{Sr}-90$ \\
\hline $05.01 \mathrm{~B}$ & $\begin{array}{l}\text { LLLW Lines and Leak Site - OHF Contaminated } \\
\text { Soil }\end{array}$ & $\begin{array}{l}\text { The leak occurred because a valve failed at the OHF. Waste grout was } \\
\text { directed to the waste pit }\end{array}$ & $\begin{array}{l}\text { Major radionuclides are } \mathrm{Sr}-90, \mathrm{Cs}-137, \mathrm{Ru}-106 \text {, } \\
\mathrm{Co}-60 \text {, and various rare earths. Some } \mathrm{Pu}, \mathrm{U} \text {, } \\
\text { and TRU isotopes were also present in the } \\
\text { waste streams }\end{array}$ \\
\hline 05.02 & OHF Pond/Pits & $\begin{array}{l}\text { The pond was designed to receive the accidental release of waste grout } \\
\text { mixture in the event of a wellhead rupture }\end{array}$ & $\begin{array}{l}\text { Main radionuclides include Cs-137, Sr-90, Co- } \\
60 \text {, and Cs-134 }\end{array}$ \\
\hline $05.05 \mathrm{~A}$ & Inactive OHF Waste Storage Tank $\mathrm{T}-1$ & The site is used to store radioactive waste prior to blending with grout & $\begin{array}{l}\text { Major radionuclides are } \mathrm{Cs}_{-}-137, \mathrm{Sr}-90, \mathrm{Co}-60 \text {, } \\
\text { and TRU materials }\end{array}$ \\
\hline 05.05B & Inactive OHF Waste Storage Tank T-2 & The site is used to store radioactive waste prior to blending with grout & $\begin{array}{l}\text { Major radionuclides are } \mathrm{Cs}-137, \mathrm{Sr}-90, \mathrm{Co}-60 \text {, } \\
\text { and TRU materials }\end{array}$ \\
\hline $05.05 \mathrm{C}$ & Inactive OHF Waste Storage Tank $\mathrm{T}-3$ & The site is used to store radioactive waste prior to blending with grout & $\begin{array}{l}\text { Major radionuclides are Cs-137, Sr-90, Co-60, } \\
\text { and TRU materials }\end{array}$ \\
\hline $05.05 \mathrm{D}$ & Inactive OHF Waste Storage Tank $\mathrm{T}-4$ & The site is used to store radioactive waste prior to blending with grout & $\begin{array}{l}\text { Major radionuclides are Cs-137, Sr-90, Co-60, } \\
\text { and TRU materials }\end{array}$ \\
\hline $05.05 \mathrm{E}$ & Inactive OHF Waste Storage Tank T-9 & The site is used to store radioactive waste prior to blending with grout & $\begin{array}{l}\text { Major radionuclides are Cs-137, Si-90, Co-60, } \\
\text { and TRU materials }\end{array}$ \\
\hline $05.05 \mathrm{~F}$ & LLLW Line from Valve Box to OHF & Data not yet available & Data not yet available \\
\hline 05.06 & Process Waste Sludge Basin (PWSB) (7835) & $\begin{array}{l}\text { The basin was used to contain and settle sludge produced by the ORNL } \\
\text { PWTP (3544). Supernatant was pumped back to the PWTP (3544) }\end{array}$ & $\begin{array}{l}\text { Sludge constituents are primarily ferrous sulfate } \\
\text { and ferric hydroxide, with fission products } \\
\text { present }\end{array}$ \\
\hline 05.07 & $\begin{array}{l}\text { SWSA } 5 \text { South (Trenches, Undefined Area, Dump, } \\
\text { Auger Holes) }\end{array}$ & $\begin{array}{l}\text { The site is composed of two distinct geographical areas providing } \\
\text { different solid waste storage functions. SWSA } 5 \text { (south) was used for } \\
\text { disposing of routine buried waste; SWSA } 5 \text { (north) is used to retrievably } \\
\text { store TRU contaminated waste }\end{array}$ & $\begin{array}{l}\text { Retrievable wastes are TRU isotopes and } \mathrm{U} \text { - } \\
\text { 233. Major wastes are contaminated with } \mathrm{Sr}- \\
90, \mathrm{Cm}-244, \mathrm{Pu}-238, \mathrm{Ru}-106, \mathrm{Cs}-137, \mathrm{Co}-60 \text {, } \\
\text { and } \mathrm{H}-3\end{array}$ \\
\hline $05.07 \mathrm{~A}$ & PWSB Pipeline from PWSB to PWTP & Data not yet available & Data not yet available \\
\hline 05.07B & Drainage 1,2 in WAG 5 & Data not yet available & Data not yet available \\
\hline
\end{tabular}


Table B.5. (continued)

\begin{tabular}{|l|l|l|l||}
\hline \multicolumn{1}{|c|}{ ID Number } & \multicolumn{1}{|c|}{ Name } & \multicolumn{1}{c|}{ Function } & \multicolumn{1}{|c|}{ Waste Characteristics } \\
\hline \hline 05.14 & Old Landfill (NE edge of SWSA 5) & $\begin{array}{l}\text { Apparently used as a dump site for noncontaminated rubbish from ORNL } \\
\text { operations. }\end{array}$ & $\begin{array}{l}\text { General rubbish, debris, metal containers and } \\
\text { other noncontaminated items }\end{array}$ \\
\hline 05.16 & Inactive LLLW Tank T-14 & $\begin{array}{l}\text { Tank T-14 is designed to collect drainage from the well cell. The tank } \\
\text { currently contains some sludge. The tank drains the overflow from the } \\
\text { well cell }\end{array}$ & $\begin{array}{l}\text { Wastes handled in the collection system were } \\
\text { routinely generated Laboratory LLLW. Major } \\
\text { radionuclides were Sr-90, Cs-137, Co-60, and } \\
\text { various rare earths. Some Pu, U, and TRU } \\
\text { isotopes were also present in the waste streams } \\
\text { from certain sources }\end{array}$ \\
\hline
\end{tabular}


Table B.6. WAG 6 site/facilities managed by the S\&M program

\begin{tabular}{|l|l|l|l||}
\hline \multicolumn{1}{|c|}{ ID Number } & \multicolumn{1}{|c|}{ Name } & & \multicolumn{1}{|c|}{ Function } \\
\hline \hline 06.01 & SWSA 6 (7822) & This site is a waste burial ground; its purpose is to contain LLLW & $\begin{array}{l}\text { Hazardous chemicals include lead, toluene, and } \\
\text { xylene. Main radionuclides include Co-60, H- } \\
3, \text { Sr-90, CS-137, Eu-152, Eu-154, Eu-155, U- } \\
235, \text { Th-232, U-233, and U-238 }\end{array}$ \\
\hline 06.02 & Emergency Waste Basin (7821) & $\begin{array}{l}\text { The basin was constructed as an LLLW or process waste holding basin } \\
\text { for use when ORNL might be unable to release wastes to WOC. The } \\
\text { basin has never been used }\end{array}$ & $\begin{array}{l}\text { No wastes have been added. Water in the basin } \\
\text { is the result of runoff from the surrounding } \\
\text { areas }\end{array}$ \\
\hline 06.03 & Explosives Detonation Trench (7822A) & $\begin{array}{l}\text { The site was used to detonate explosives and shock-sensitive chemicals } \\
\text { requiring disposal. Waste was laid in the bottom of the trench and } \\
\text { detonated with a small plastic explosive charge }\end{array}$ & $\begin{array}{l}\text { Items detonated at the trench included } \\
\text { chemicals such as picric acid, phosphorus, } \\
\text { nitromethane, hydrogen peroxide, and } \\
\text { ammonium nitrate }\end{array}$ \\
\hline
\end{tabular}


Table B.7. WAG 7 site/facilities managed by the S\&M program

\begin{tabular}{|c|c|c|c|}
\hline ID Number & Name & Function & Waste Characteristics \\
\hline 07.02 & $\begin{array}{l}\text { Homogeneous Reactor Experiment (HRE) Fuel Wells } \\
\text { (7809) }\end{array}$ & $\begin{array}{l}\text { Designed to hold residual fuel solution from the Homogeneous Reactor. } \\
\text { Fuel was stored in the Homogeneous Reactor Chemical Plant decay tanks }\end{array}$ & $\mathrm{U}$, fission products, Sr-90, and Ru-106 \\
\hline 07.03 & $\begin{array}{l}\text { Hydrofracture Experimental Site 1, Soil } \\
\text { Contamination (HF-SIA) }\end{array}$ & $\begin{array}{l}\text { The spill occurred when the injected grout sheet intercepted a nearby } \\
\text { open core hole and overflowed from the core hole. Grout was being } \\
\text { injected to investigate the feasibility of using hydrofracturing as a means } \\
\text { of LLLW disposal }\end{array}$ & $\begin{array}{l}\text { Grout was tagged with Cs-137 and Ce-144 } \\
\text { prior to injection. No LLLW was used. The } \\
\text { grout should not contain hazardous constituents } \\
\text { other than radioactivity }\end{array}$ \\
\hline $07.04 \mathrm{~A}$ & Gauging Station Northwest of Building 7852 & $\begin{array}{l}\text { The LLLW line transports evaporator-concentrated low-level radioactive } \\
\text { liquid wastes to waste disposal facilities in Melton Valley }\end{array}$ & $\begin{array}{l}\text { Wastes handled in the transfer system were } \\
\text { routinely generated laboratory LLLW. Major } \\
\text { radionuclides were Sr-90, Cs-137, Ru-106, Co- } \\
60 \text {, and various rare earths. Some } \mathrm{Pu}, \mathrm{U} \text {, and } \\
\text { TRU isotopes were also present in the waste } \\
\text { streams from certain sources }\end{array}$ \\
\hline 07.04B & Pit 6 Southeast (Leak Site 1) & $\begin{array}{l}\text { The leak was in the cast-iron LLLW transfer line between ORNL and the } \\
\text { OHF, approximately } 150 \mathrm{ft}(45 \mathrm{~m}) \text { south of Trench } 6 \text {. The line was used } \\
\text { to transfer waste for disposal by hydrofracture }\end{array}$ & $\begin{array}{l}\text { Wastes handled in the transfer system were } \\
\text { evaporator-concentrated LLLW. Major } \\
\text { radionuclides were } \mathrm{Sr}-90, \mathrm{Cs}-137, \mathrm{RU}-106, \mathrm{Co}- \\
60 \text {, and various rare earths. Some } \mathrm{Pu}, \mathrm{U} \text {, and } \\
\text { TRU isotopes were also present in the waste } \\
\text { streams }\end{array}$ \\
\hline $07.04 \mathrm{C}$ & End of Trench 7 Access Road (Leak Site 2) & $\begin{array}{l}\text { The transfer line was designed to transport LLLW from Bethel Valley } \\
\text { Storage tanks to the OHF }\end{array}$ & The waste was evaporator concentrated LLLW \\
\hline 07.04D & $\begin{array}{l}\text { Leak in Transfer Line from Decontamination Facility } \\
\text { (7819) to Pit } 1 \text { (7805) }\end{array}$ & $\begin{array}{l}\text { A } 6 \text {-in. (15-cm) drain line served to transfer decontamination waste } \\
\text { solutions from the Decontamination Facility (Bldg. 7819, SWMU 07.01) } \\
\text { to LLLW Pit } 1 \text { (bldg. } 7805 \text {, SWMU 07.05) }\end{array}$ & $\begin{array}{l}\text { Cs-137 is the dominant radionuclide in soils } \\
\text { around the facility. It is believed that the } \\
\text { wastes from Building } 7819 \text { would consist of } \\
\text { corrosive wastes (i.e., acids) and radionuclides } \\
\text { associated with the equipment being } \\
\text { decontaminated }\end{array}$ \\
\hline $07.04 \mathrm{E}$ & $\begin{array}{l}\text { Leak in Line Between Pit } 3 \text { (7807) and Trench } 6 \\
(7810)\end{array}$ & $\begin{array}{l}\text { The valve box was used to divert waste from the Main Plant Area (WAG } \\
\text { 1) to either Waste Pit } 3 \text { or Waste Trench } 6\end{array}$ & $\begin{array}{l}\text { Wastes handled in the collection system were } \\
\text { routinely generated Laboratory LLLW. Major } \\
\text { radionuclides were Sr-90, Cs-137, Co-60, and } \\
\text { various rare earths. Some Pu, U, and TRU } \\
\text { isotopes were also present in the waste streams } \\
\text { from certain sources }\end{array}$ \\
\hline
\end{tabular}


Table B.7. (continued)

\begin{tabular}{|c|c|c|c|}
\hline ID Number & Name & Function & Waste Characteristics \\
\hline $07.04 \mathrm{~F}$ & Leak at Valve Pit North of Trench 7 (7818) & $\begin{array}{l}\text { Transfer LLLW from the Main Plant Area (WAG 1) to Waste Trench } 7 \\
\text { and the OHF (SWMU 05.03) }\end{array}$ & $\begin{array}{l}\text { Wastes handled in the collection system were } \\
\text { routinely generated Laboratory LLLW. Major } \\
\text { radionuclides were Sr-90, Cs-137, Co-60, and } \\
\text { various rare earths. Some Pu, U, and TRU } \\
\text { isotopes were also present in the waste streams } \\
\text { from certain sources }\end{array}$ \\
\hline 07.05 & Pit 1 (7805) & The purpose of the pit was to hold concentrated liquid waste & $\begin{array}{l}\text { Cs-137, Ru-106, U, and Pu. The nature of the } \\
\text { waste that was discharged into the pit between } \\
1962 \text { and } 1964 \text { is unknown. The total activity } \\
\text { was probably small }\end{array}$ \\
\hline $07.06 \mathrm{~A}$ & Pit 2 (7806) & The pit was built to dispose of LLLW & Ru-106, Cs-137, Sr-90, TREs \\
\hline 07.06B & Pit $3(7807)$ & The pit was built to dispose of LLLW & Sr-90, Cs-137, Ru-106, TREs \\
\hline $07.06 \mathrm{C}$ & Pit 4 (7808) & The pit was built to dispose of LLLW & Sr-90, Cs-137, Ru-106, TREs \\
\hline 07.07 & Trench 5 (7809) & The site was built to dispose of LLLW & Cs-137, Ru-106, Sr-89, Sr-90, Co-60 \\
\hline 07.08 & Trench $6(7810)$ & The site was built to dispose of LLLW & Cs-137, Ru-106, Sr-90, Co-60 \\
\hline 07.09 & Trench 7 (7818) & The site was built to dispose of LLLW & Cs-137, Ru-106, Sr-90, Co-60 \\
\hline 07.11 & Septic Tank 7819 & $\begin{array}{l}\text { Septic tank is used to collect and dispose of raw domestic sewage from } \\
\text { Building } 7819 \text { (Decontamination Facility) }\end{array}$ & $\begin{array}{l}\text { Only domestic sewage from building } 7819 \text { has } \\
\text { been collected/stored in the tank. No hazardous } \\
\text { or radioactive wastes have been added to the } \\
\text { system }\end{array}$ \\
\hline 07.12 & Equipment Storage Area (7841) & $\begin{array}{l}\text { Used as an aboveground storage area for surplus tanks and other } \\
\text { equipment }\end{array}$ & Soil may be contaminated with fission products \\
\hline
\end{tabular}

$\infty$ 
Table B.8. WAG 8 site/facilities managed by the S\&M program

\begin{tabular}{|c|c|c|c|}
\hline ID Number & Name & Function & Waste Characteristics \\
\hline $08.01 \mathrm{~A}$ & $\begin{array}{l}\text { High Flux Isotope Reactor (HFIR)/TRU Waste } \\
\text { Collection Basin - (7905) }\end{array}$ & $\begin{array}{l}\text { This basin was called the Cold Pond and was formerly used as an } \\
\text { intermediate storage and collection basin for liquid wastes from the HFIR } \\
\text { facility. The basin also served as an emergency storage basin for the } \\
\text { radiologically contaminated blowdown water from the cooling tower in } \\
\text { Building } 7902 \text {. The waste streams collected consist of floor drain, } \\
\text { laboratory drains, steam condensates, process vessel cooling water, and } \\
\text { precipitation falling directly on the basin }\end{array}$ & $\begin{array}{l}\text { Co-60 is the major radionuclide that is present. } \\
\text { Waste streams consisted of floor drains, } \\
\text { laboratory drains, stream condensates, and } \\
\text { process vessel cooling water containing nitric } \\
\text { acid, sodium hydroxide, and sulfuric acid }\end{array}$ \\
\hline $08.01 \mathrm{~B}$ & HFIR/RU Waste Collection Basin - (7906) & $\begin{array}{l}\text { In addition to receiving liquid wastes from HFIR, Basin } 7906 \text { could also } \\
\text { receive diverted waste streams from Thorium-Uranium Recycle Facility } \\
\text { (TURF) and the Transuranium Processing Plant (TPP). This basin was } \\
\text { called the Hot Pond because it received wastes that were thought to } \\
\text { contain radionuclides }\end{array}$ & Co-60, sodium, potassium hydroxide, acids \\
\hline $08.01 \mathrm{C}$ & HFIRTRU Waste Collection Basin - (7907) & $\begin{array}{l}\text { The basin was designed to receive process waste streams from the TPP. } \\
\text { During operation, Basin } 7907 \text { was filled and emptied altemately with } \\
\text { Basin 7908. Waste streams were derived from floor drains, laboratory } \\
\text { drains, steam condensates, and process vessel cooling waters. The basin } \\
\text { was also called the Number } 3 \text { Pond or the TPP A Pond }\end{array}$ & $\begin{array}{l}\text { The major radionuclide in the process waste } \\
\text { was } \mathrm{Cm}-244\end{array}$ \\
\hline 08.01D & HFIR/TRU Waste Collection Basin - (7908) & $\begin{array}{l}\text { The basin was designed to receive process waste streams from the TPP. } \\
\text { During operation, Basin } 7908 \text { was filled and emptied altemately with } \\
\text { Basin } 7907 \text {. Waste streams were derived from floor drains, laboratory } \\
\text { drains, steam condensates, and process vessel cooling waters. The basin } \\
\text { was also called the TPP B Pond }\end{array}$ & $\begin{array}{l}\text { The major radionuclide in the process waste } \\
\text { was } \mathrm{Cm}-244\end{array}$ \\
\hline 08.02 & Hydrofracture Experimental Site 2 (HF-S2A) & $\begin{array}{l}\text { This site was the second test facility for testing the use of hydrofracturing } \\
\text { as a method of LLLW disposal: It was set up so that a deeper injection } \\
\text { well could be used in an area of known geology }\end{array}$ & $\begin{array}{l}\text { A total of } 50 \mathrm{Ci} \text { of } \mathrm{Cs}-137 \text { was injected. No } \\
\text { hazardous chemicals other than the radioactivity } \\
\text { were added }\end{array}$ \\
\hline 08.03A & $\begin{array}{l}\text { LLLW Lines and Leak Sites - Lagoon Road and } \\
\text { Melton Valley Drive }\end{array}$ & $\begin{array}{l}\text { The Melton Valley transfer line was installed to allow wastes generated in } \\
\text { Buildings } 7500 \text { and } 7503 \text { to be pumped to the main plant storage tanks } \\
\text { and the evaporator prior to disposal }\end{array}$ & $\begin{array}{l}\text { Waste handled in the collection system were } \\
\text { routinely generated Laboratory LLLW. Major } \\
\text { radionuclides were Sr-90, Cs-137, Ru-106, Co- } \\
60 \text {, and various rare earths. Some } \mathrm{Pu}, \mathrm{U} \text {, and } \\
\text { TRU isotopes were also present in the waste } \\
\text { streams }\end{array}$ \\
\hline
\end{tabular}


Table B.8. (continued)

\begin{tabular}{|c|c|c|c|}
\hline ID Number & Name & Function & Waste Characteristics \\
\hline 08.03B & $\begin{array}{l}\text { LLLW Lines and Leak Sites - Melton Valley Drive } \\
\text { and SWSA } 5 \text { Access Road }\end{array}$ & $\begin{array}{l}\text { The main plant area LLLW collection system was installed in the } 1940 \text { s } \\
\text { to transfer wastes from various sources to the collection and storage tanks. } \\
\text { The original system was constructed of cast-iron pipe; more recent } \\
\text { additions and modifications are of stainless steel. Many of the reported } \\
\text { leak/spill sites are located near the collection and storage tanks serving the } \\
\text { LLLW lines; others are along the lines themselves; and still others are not } \\
\text { leaks at all but are spills, e.g., from pumping accidents }\end{array}$ & $\begin{array}{l}\text { Wastes handled in the collection system were } \\
\text { routinely generated laboratory LLLW. Major } \\
\text { radionuclides were Sr-90, CS-137, Ru-106, Co- } \\
60 \text {, and various rare earths. Some Pu, U, and } \\
\text { TRU isotopes were also present in the waste } \\
\text { streams }\end{array}$ \\
\hline $08.03 \mathrm{C}$ & LLLW Lines and Leak Sites - 7500 Area & $\begin{array}{l}\text { The Melton Valley waste transfer line was used to transport LLLW from } \\
\text { Melton Valley reactor facilities to the main ORNL plant area for storage } \\
\text { and treatment prior to disposal }\end{array}$ & $\begin{array}{l}\text { Wastes handled in the collection system were } \\
\text { routinely generated laboratory LLLW. Major } \\
\text { radionuclides were Sr-90, Cs-137, Ru-106, Co- } \\
60 \text {, and various rare earths. Some } \mathrm{Pu}, \mathrm{U} \text {, and } \\
\text { TRU isotopes were also present in the waste } \\
\text { streams. The contamination was } \mathrm{Cm}-244 \text { and a } \\
\text { mixture of fission products }\end{array}$ \\
\hline 08.03D & $\begin{array}{l}\text { LLLW Lines and Leak Sites - West of Melton Valley } \\
\text { Pumping Station }\end{array}$ & $\begin{array}{l}\text { This line was used to transfer liquid waste from Melton Valley to the } \\
\text { Tank Farm }\end{array}$ & $\begin{array}{l}\text { Wastes handled in the collection system were } \\
\text { routinely generated Laboratory LLLW. Major } \\
\text { radionuclides were Sr-90, Cs-137, Ru-106, Co- } \\
60 \text {, and various rare earths. Some Pu, U, and } \\
\text { TRU isotopes were also present in the waste } \\
\text { streams }\end{array}$ \\
\hline 08.03E & $\begin{array}{l}\text { LLLW Lines and Leak Sites - Building } 7920 \text { and } \\
\text { Melton Valley Pumping Station }\end{array}$ & $\begin{array}{l}\text { The transfer line is used to transport waste from the TPP (Building 7920) } \\
\text { to the Melton Valley Pumping Station and then to the main ORNL plant } \\
\text { area }\end{array}$ & $\begin{array}{l}\text { LLLW resulting from hot cell operations in } \\
\text { Building } 7920 \text { related to recovery of certain } \\
\text { transuranic elements for R\&D operations. } \\
\text { LLLW should contain some Pu, } U \text {, and } \\
\text { transuranic isotopes plus the usual nuclides } \\
\text { found in ORNL LLLW }\end{array}$ \\
\hline $08.03 \mathrm{~F}$ & LLLW Lines and Leak Sites - 7920 Ditch Line & $\begin{array}{l}\text { The transfer line transports waste from Building } 7920 \text { to the Melton } \\
\text { Valley Pumping Station }\end{array}$ & $\begin{array}{l}\text { LLLW resulting from hot cell operations in } \\
\text { Building } 7920 \text { related to recovery of certain } \\
\text { transuranic elements for R\&D operations. } \\
\text { LLLW should contain some Pu, } U \text {, and } \\
\text { transuranic isotopes plus the usual nuclides } \\
\text { found in ORNL LLLW }\end{array}$ \\
\hline
\end{tabular}


Table B.8. (continued)

\begin{tabular}{|c|c|c|c|}
\hline ID Number & Name & Function & Waste Characteristics \\
\hline $08.03 G$ & $\begin{array}{l}\text { LLLW Lines and Leak Sites - Melton Valley } \\
\text { Transfer Line }\end{array}$ & $\begin{array}{l}\text { The new line connects the Melton Valley Pumping Station and the } \\
\text { evaporator service tanks }\end{array}$ & $\begin{array}{l}\text { Wastes handled in the collection system were } \\
\text { routinely generated laboratory LLLW. Major } \\
\text { radionuclides were Sr-90, Cs-137, Ru-106, Co- } \\
60 \text {, and various rare earths. Some } \mathrm{Pu}, \mathrm{U} \text {, and } \\
\text { TRU isotopes were also present in the waste } \\
\text { streams from certain sources }\end{array}$ \\
\hline 08.13 & $\begin{array}{l}\text { Contractor Spoils Area - Melton Valley, W-SW of } \\
7900\end{array}$ & $\begin{array}{l}\text { This site is believed to have been used as a dump site for the disposal of } \\
\text { general construction debris. It was used during construction operations at } \\
\text { the } 7900 \text { Area, the HFIR/TPP facilities }\end{array}$ & $\begin{array}{l}\text { Materials observed at the site include scrap } \\
\text { wood and metal, empty paint cans, empty } \\
\text { drums and 5-gallon cans, and asphalt. In } \\
\text { addition to the general construction debris, a } \\
\text { small piece of sheet lead was found. The } \\
\text { presence of any additional hazardous material is } \\
\text { undetermined }\end{array}$ \\
\hline 08.14 & HFIR Cooling Tower Surface Impoundment & $\begin{array}{l}\text { Used to contain cooling tower blowdown during experiments related to } \\
\text { chromate removal }\end{array}$ & $\begin{array}{l}\text { Typical cooling tower blowdown which } \\
\text { contained } 0.60 \text { and chromium }\end{array}$ \\
\hline 08.15 & $\begin{array}{l}\text { Aircraft Reactor Experiment (ARE) Surface } \\
\text { Impoundment }\end{array}$ & $\begin{array}{l}\text { Was to be used to handle water used to flood the reactor pits after } \\
\text { operation. Following operation of the reactor the liquid fuel could be } \\
\text { drained from the reactor, leaving about } 15 \text { percent of the fuel in the } \\
\text { reactor and piping. Apparently water flooding was not used in the ARE. } \\
\text { The ARE was located in Building 7503, the current site of the inactive } \\
\text { Molten Salt Reactor Experiment (MSRE) }\end{array}$ & No reported information \\
\hline 08.16 & MSRE Storage Well & Used to store radioactively contaminated maintenance tools & $\begin{array}{l}\text { Sample of water in the well was reported to } \\
\text { contain Cs-137 }\end{array}$ \\
\hline 08.17 & $\begin{array}{l}\text { Abandoned Sanitary Waste Pipeline and Septic Tank } \\
\text { North of } 7917\end{array}$ & $\begin{array}{l}\text { Septic tank was used to collect and dispose of raw domestic sewage from } \\
\text { Building } 7910\end{array}$ & $\begin{array}{l}\text { Only domestic sewage has been collected/stored } \\
\text { in the tank. No hazardous or radioactive wastes } \\
\text { should have been added to the system }\end{array}$ \\
\hline 08.20 & Inactive LLLW Collection Tank 7503A & Collect LLLW from MSRE reactor operations & $\begin{array}{l}\text { Not reported. Probably contained Sr-90, Cs- } \\
137, \text { Co-60, and U isotopes }\end{array}$ \\
\hline 08A.01G & HRE Contaminated Tool Storage & Apparently used for storage of contaminated items from the ARE (ARE) & Unknown \\
\hline
\end{tabular}


Table B.9. WAG 9 site/facilities managed by the S\&M program

\begin{tabular}{|c|c|c|c|}
\hline ID Number & Name & Function & Waste Characteristics \\
\hline 09.01 & HRE Settling Pond (7556) & $\begin{array}{l}\text { The pond was supposed to receive contaminated condensate from the } \\
\text { reactor evaporator. Later, shield water was also added to the pond }\end{array}$ & $\begin{array}{l}\text { Contamination is mainly from } \mathrm{Cs}-137 \text { and } \mathrm{Sr}- \\
90 \text {, with trace amounts of } \mathrm{Pu}-238, \mathrm{Pu}-239, \mathrm{Am}- \\
241 \text {, and } \mathrm{Cm}-244\end{array}$ \\
\hline $09.02 \mathrm{~A}$ & LLLW Collection and Storage Tank 7560 & $\begin{array}{l}\text { This tank held condensed clean vapor from the evaporator cell; this liquid } \\
\text { was stored for sampling. Depending on its radioactivity, the condensate } \\
\text { was either sent to the retention pond or to the } 12,000 \text {-gal tank for } \\
\text { recycling }\end{array}$ & $\begin{array}{l}\text { Major radionuclides of concern in LLLW are } \\
\text { considered to be } \mathrm{Sr}-90, \mathrm{Cs}-137, \mathrm{Co}-60 \text {, and } \\
\text { TRU. Some } \mathrm{U} \text { or } \mathrm{Pu} \text { isotopes may also be } \\
\text { contained in the waste }\end{array}$ \\
\hline $09.02 \mathrm{~B}$ & LLLW Collection and Storage Tank 7562 & $\begin{array}{l}\text { The } 12,000 \text {-gal }(45,425-\mathrm{L}) \text { tank was designed to hold high-level waste. } \\
\text { Tank functioned as feed to the evaporator }\end{array}$ & $\begin{array}{l}\text { Major radionuclides of concern in LLLW are } \\
\text { considered to be Sr-90, Cs-137, Co- } 60 \text {, and } \\
\text { TRU. Some } \mathrm{U} \text { or } \mathrm{Pu} \text { isotopes may also be } \\
\text { contained in the waste }\end{array}$ \\
\hline 09.04 & Trash Area East of HRE Parking Lot & $\begin{array}{l}\text { The site formerly contained an old farm house that was used by HRE-1 } \\
\text { and HRE-2 for storage. During the early to middle } 1960 \text { 's, all stored } \\
\text { material, some contaminated with radioactivity, was removed for disposal. } \\
\text { The farm house was demolished and most of the debris was removed. } \\
\text { The site was leveled and converted into a parking lot. Later the parking } \\
\text { lot was expanded and it appears that the visible debris (wood, concrete, } \\
\text { plastic) at the east end of the area may have been placed at this site at the } \\
\text { time of expansion. Current use of the site includes a packing lot and a } \\
\text { storage area for construction materials }\end{array}$ & $\begin{array}{l}\text { Construction debris, perhaps some waste } \\
\text { contaminated with radionuclides }\end{array}$ \\
\hline
\end{tabular}


Table B.10. WAG 10 site/facilities managed by the S\&M program

\begin{tabular}{|c|c|c|c|}
\hline ID Number & Name & Function & Waste Characteristics \\
\hline 10.01 & Hydrofracture Experiment Site 1 & $\begin{array}{l}\text { This site was the first experimental injection of grout as a testing program } \\
\text { for observing the fracture pattem created in the shale and to identify } \\
\text { potential operating problems }\end{array}$ & $\begin{array}{l}\text { Waste injected was water tagged with Cs-137 } \\
\text { and cerium (Ce)-141. Grout consisted of } \\
\text { diatomaceous earth and cement. No LLLW } \\
\text { was used. No hazardous waste constituents } \\
\text { should have been present in the grout }\end{array}$ \\
\hline 10.02 & Hydrofracture Experiment Site 2 & $\begin{array}{l}\text { The second hydrofracture experiment was designed to duplicate in scale } \\
\text { an actual disposal operation. However, radioactive tracers were used } \\
\text { instead of actual waste }\end{array}$ & $\begin{array}{l}\text { Water tagged with Cs-137, cement, and } \\
\text { bentonite was used in formulating the grout. } \\
\text { No nonradioactive hazardous constituents } \\
\text { should be contained in the grout }\end{array}$ \\
\hline 10.03 & Old Hydrofracture Injection Well (7852) & $\begin{array}{l}\text { The facility served as a pilot plant to demonstrate the feasibility of } \\
\text { permanent disposal of liquid radioactive waste in impermeable shale } \\
\text { formations by hydrofracture methods }\end{array}$ & $\begin{array}{l}\text { Sr-90, Cs- } 137, \mathrm{Cm}-244, \mathrm{TRU} \text {, and other } \\
\text { unidentified radionuclides }\end{array}$ \\
\hline 10.04 & New Hydrofracture Injection Well & $\begin{array}{l}\text { The facility was constructed to replace the OHF and serve as the } \\
\text { operational LLW waste disposal system for ORNL }\end{array}$ & $\begin{array}{l}\text { Waste use in the injections was concentrated } \\
\text { LLLW and sludge removed from the gunite } \\
\text { tanks in the South Tank Farm. The grout } \\
\text { contained Sr-90, Cs-137, Cm-244, TRU and } \\
\text { other nuclides }\end{array}$ \\
\hline $10.04 \mathrm{~A}$ & Grout Sheets & Data not yet available & Data not yet available \\
\hline 00.52 & WAG 10 Groundwater & & \\
\hline
\end{tabular}

Do 
Table B.11. WAG 11 site/facilities managed by the S\&M program

\begin{tabular}{|c|c|c|c|}
\hline ID Number & Name & Function & Waste Characteristics \\
\hline 11.01 & WWSY (XD0751) & $\begin{array}{l}\text { The site was used to store contaminated materials (equipment, tanks, and } \\
\text { trucks) from the three Oak Ridge plants. Waste was stored aboveground. } \\
\text { Much of the stored materials and contaminated soils was removed in } \\
\text { 1966-1971; however, some scrap metal, concrete, and other waste remains } \\
\text { at the site }\end{array}$ & $\begin{array}{l}\text { About } 0.05 \mathrm{lb}(25 \mathrm{~g}) \text { of Pu- } 239 \text { was estimated } \\
\text { to be on or in the material from ORNL that was } \\
\text { stored at the site. No records are available on } \\
\text { wastes from other Oak Ridge plants. In } 1971 \text {, a } \\
\text { radiation survey detected } 0.8 \text { to } 6.0 \mathrm{mR} / \mathrm{h} \\
\text { gamma exposure rate and } 0.5 \text { to } 4.0 \mathrm{mR} / \mathrm{h} \\
\text { exposure rate for Cs-137. An aerial survey in } \\
1974 \text { indicated the presence of Cs-137 } \\
\text { (estimated at } 25 \text { to } 100 \mathrm{mCi} \text { ), Th-234, and U- } \\
235\end{array}$ \\
\hline
\end{tabular}


Table B.12. WAG 13 site/facilities managed by the S\&M program

\begin{tabular}{|c|c|c|c|}
\hline ID Number & Name & Function & Waste Characteristics \\
\hline 13.01 & Cs-137 Contaminated Plots (0816) & $\begin{array}{l}\text { The area was set aside to study simulated fallout of Cs-137, which would } \\
\text { occur in the event of a nuclear war }\end{array}$ & $\begin{array}{l}\text { The contaminant consisted of Cs-137 fused at } \\
\text { high temperature to silica particles. Each of the } \\
\text { four enclosures received about } 2.2 \mathrm{Ci} \text { of } \\
\text { radioactivity, for a total of } 8.8 \mathrm{Ci} \text {. After } 20 \\
\text { years (since contamination), about } 5.5 \mathrm{Ci} \text { of } \\
\text { activity should remain }\end{array}$ \\
\hline 13.02 & Cs-137 Erosion/Runoff Study Area (0807) & $\begin{array}{l}\text { The objective was to use the field contamination to study runoff, erosion, } \\
\text { and infiltration of Cs-137 on a silt-loam soil }\end{array}$ & Cs-137 was applied to the soil in a liquid spray \\
\hline
\end{tabular}


Appendix C

SUMMARY OF TANK LEVEL TRENDING ACTIVITIES 



\section{C.1. INTRODUCTION}

ORNL has a total of 54 inactive LLLW tanks. In the past, these tanks were used to contain radioactive liquid wastes from various research programs, decontamination operations, and reactor operations. The tanks have since been removed from service for various reasons; the majority were retired because of their age, some due to integrity compromises, and others because they did not meet the current standards set by the Federal Facilities Agreement (FFA). Many of the tanks contain residual radioactive liquids and/or sludges. Plans are to remediate all tanks; however, until remediation, each tank requires monitoring to ensure the safety and inventory containment of these tanks. The ER Program, as Operations Manager of the inactive LLLW tanks, manages all programs associated with the inactive LLLW tanks. Personnel within the line organization of the Waste Management and Remedial Action Division (WMRAD) at ORNL have been commissioned by the ORNL ER Program Managers to operate as FMs for the inactive LLLW tanks.

Table 1 is a summary of pertinent information concerning the inactive LLLW tanks such as location, capacities, material of construction, and level measurement instrumentation of the tank contents. Figure C- 1 shows the location of the 45 tanks in the main plant area, and Fig. C-2 shows the location of the nine tanks in Melton Valley. 
Table C.1. Summary of inactive liquid low-level waste (ILLLW) tanks

\begin{tabular}{|c|c|c|c|c|c|}
\hline Tank & Location & $\begin{array}{l}\text { Material of } \\
\text { construction }\end{array}$ & $\begin{array}{c}\text { Tank } \\
\text { capacity } \\
\text { (gal) }\end{array}$ & $\begin{array}{c}\text { Level } \\
\text { detection }\end{array}$ & $\begin{array}{l}\text { Frequency of } \\
\text { level } \\
\text { measurement }\end{array}$ \\
\hline W-5 & South Tank Farm & Gunite & 170,000 & conductivity probe & continuous \\
\hline W-6 & South Tank Farm & Gunite & 170,000 & conductivity probe & continuous \\
\hline W-7 & South Tank Farm & Gunite & 170,000 & conductivity probe & continuous \\
\hline $\mathrm{W}-8$ & South Tank Farm & Gunite & 170,000 & conductivity probe & continuous \\
\hline W-9 & South Tank Farm & Gunite & 170,000 & conductivity probe & continuous \\
\hline W-10 & South Tank Farm & Gunite & 170,000 & conductivity probe & continuous \\
\hline W-11 & SE of South Tank Farm & Gunite & 1,500 & staff gauge & daily \\
\hline $\mathrm{T}-1$ & Old Hydrofracture Facility & Carbon steel & 15,000 & pneumatic gauge & daily \\
\hline $\mathrm{T}-2$ & Old Hydrofracture Facility & Carbon steel & 15,000 & pneumatic gauge & daily \\
\hline T-3 & Old Hydrofracture Facility & CS/rubber lined & 25,000 & pneumatic gauge & daily \\
\hline $\mathrm{T}-4$ & Old Hydrofracture Facility & CS/rubber lined & 25,000 & pneumatic gauge & daily \\
\hline T-9 & Old Hydrofracture Facility & Carbon steel & 13,000 & pneumatic gauge & daily \\
\hline TH-1 & S. of Bldg. 3503 & SS & 2,500 & none & yearly \\
\hline TH-2 & S. of Bldg. 3503 & SS & 2,400 & none & yearly \\
\hline TH-3 & S. of Bldg. 3503 & SS & 3,300 & none & yearly \\
\hline TH-4 & S. of Bldg. 3500 & Gunite & 14,000 & conductivity probe & daily \\
\hline W-1 & North Tank Farm & Gunite & 4,800 & conductivity probe & daily \\
\hline W-2 & North Tank Farm & Gunite & 4,900 & conductivity probe & daily \\
\hline W-3 & North Tank Farm & Gunite & 42,500 & staff gauge & daily \\
\hline $\mathrm{W}-4$ & North Tank Farm & Gunite & 42,500 & staff gauge & daily \\
\hline$W-13$ & North Tank Farm & SS & 2,000 & staff gauge & yearly \\
\hline W-14 & North Tank Farm & SS & 2,000 & staff gauge & yearly \\
\hline W-15 & North Tank Farm & SS & 2,000 & staff gauge & yearly \\
\hline W-1A & North Tank Farm & SS & 2,000 & pneumatic gauge & continuous \\
\hline WC-1 & E. of Bldg. 3038 & SS & 2,150 & none & yearly \\
\hline
\end{tabular}


Table 1. (continued)

\begin{tabular}{|c|c|c|c|c|c|}
\hline Tank & Location & $\begin{array}{l}\text { Material of } \\
\text { construction }\end{array}$ & $\begin{array}{c}\text { Tank } \\
\text { capacity } \\
\text { (gal) }\end{array}$ & $\begin{array}{c}\text { Level } \\
\text { detection }\end{array}$ & $\begin{array}{c}\text { Frequency of } \\
\text { level } \\
\text { measurement }\end{array}$ \\
\hline WC-15 & S. of Bldg. 3587 & SS & 1,000 & conductivity probe & daily \\
\hline WC-17 & S. of Bldg. 3587 & SS & 1,000 & pneumatic gauge & continuous \\
\hline 7560 & E. of Bldg. 7500 & SS & 1,000 & none & yearly \\
\hline 7562 & SE of Bldg. 7500 & SS & 12,000 & pneumatic gauge & daily \\
\hline$T-30$ & S. of Bldg. 4507 & SS & 825 & pneumatic gauge & daily \\
\hline W-19 & S. of South Tank Farm & SS & 2,250 & none & yearly \\
\hline $\mathrm{W}-20$ & S. of South Tank Farm & SS & 2,250 & none & yearly \\
\hline 3001-B & S. of Bldg. 3001 & SS & 75 & none & yearly \\
\hline 3003-A & S. of Bldg. 3003 & Concrete & 16,000 & none & biannually \\
\hline 3004-B & NE of Bldg. 3017 & SS & 30 & none & biannually \\
\hline 3013 & E. of Bldg. 3017 & SS & 400 & none & biannually \\
\hline 7503-A & Inside Bldg. 7503 & SS & 11,000 & none & once/3 years \\
\hline H-209 & SW of Bldg. 3517 & SS & 2,500 & none & biannually \\
\hline $3002-A$ & S. of Bldg. 3002 & SS & 1,600 & none & daily \\
\hline 4501-P & Under Basement of Bldg. 4501 & SS & 140 & none & yearly \\
\hline$S-424$ & NW of Bldg. 3517 & SS/Glass lined & 500 & pneumatic gauge & daily \\
\hline T-14 & New Hydrofracture Facility & Concrete & 48,500 & pneumatic gauge & daily \\
\hline W-17 & South Tank Farm & SS & 1,000 & pneumatic gauge & continuous \\
\hline W-18 & South Tank Farm & SS & 1,000 & pneumatic gauge & continuous \\
\hline W-1-I & Under Bldg. 3028 & SS & 500 & pneumatic gauge & daily \\
\hline WC-4 & W. of Bldg. 3026 & SS & 1,700 & pneumatic gauge & continuous \\
\hline WC-5 & S. of Bldg. 3503 & SS & 1,000 & pneumatic gauge & continuous \\
\hline WC-6 & S. of Bldg. 3503 & SS & 500 & pneumatic gauge & continuous \\
\hline WC-8 & S. of Bldg. 3503 & SS & 1,000 & pneumatic gauge & continuous \\
\hline
\end{tabular}


Table 1. (continued)

\begin{tabular}{lllccc}
\hline Tank & \multicolumn{1}{c}{ Location } & \multicolumn{1}{c}{$\begin{array}{c}\text { Material of } \\
\text { construction }\end{array}$} & $\begin{array}{c}\text { Tank } \\
\text { capacity } \\
\text { (gal) }\end{array}$ & $\begin{array}{c}\text { Level } \\
\text { detection }\end{array}$ & $\begin{array}{c}\text { Frequency of } \\
\text { level } \\
\text { measurement }\end{array}$ \\
\hline WC-11 & S. of Bldg. 3587 & SS & 4,000 & pneumatic gauge & continuous \\
WC-12 & S. of Bldg. 3587 & SS & 1,000 & pneumatic gauge & continuous \\
WC-13 & S. of Bldg. 3587 & SS & 1,000 & pneumatic gauge & continuous \\
WC-14 & S. of Bldg. 3587 & SS & 1,000 & pneumatic gauge & continuous \\
W-12 & SE of South Tank Farm & SS & 700 & pneumatic gauge & continuous \\
\hline
\end{tabular}




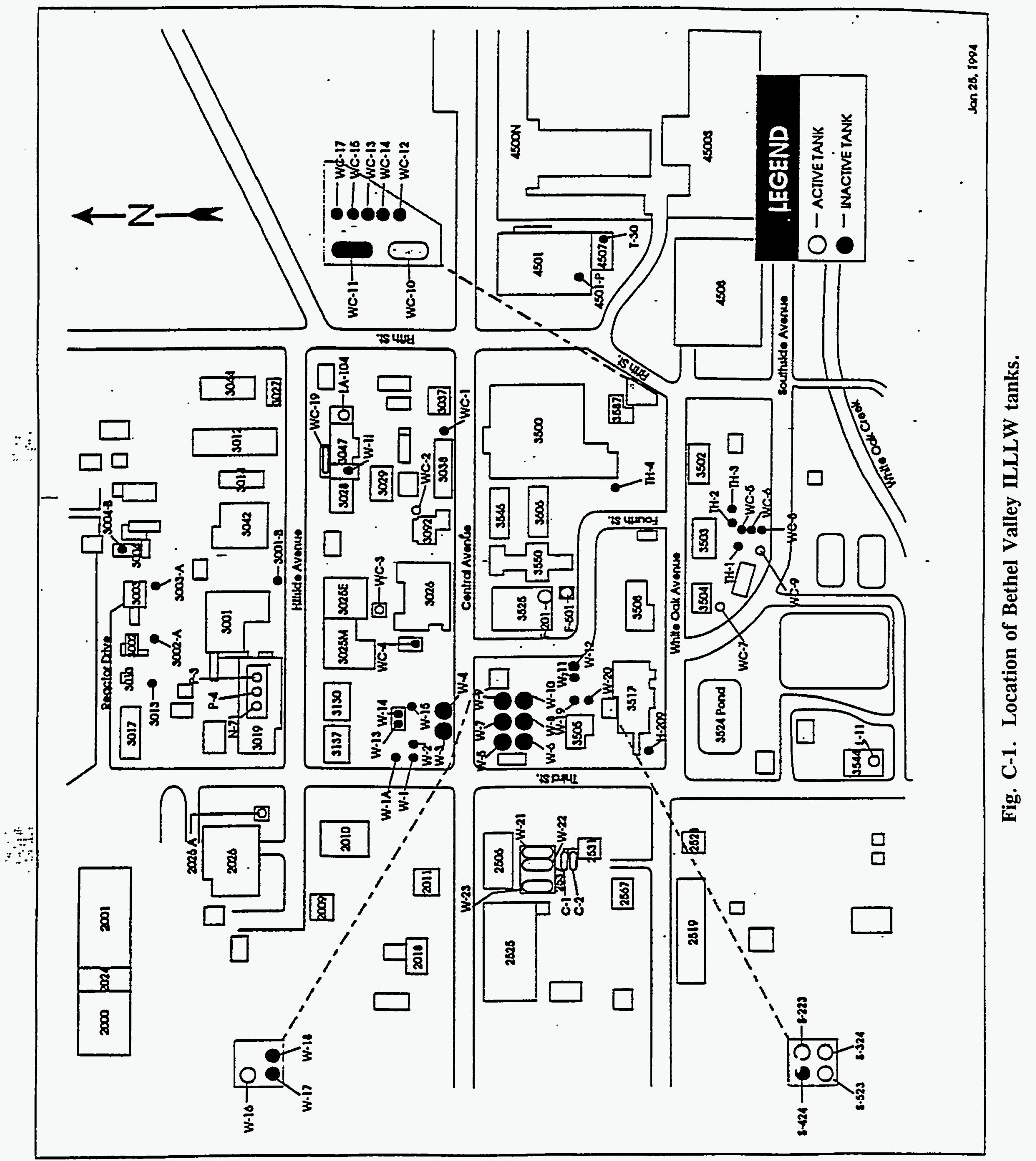


C -8

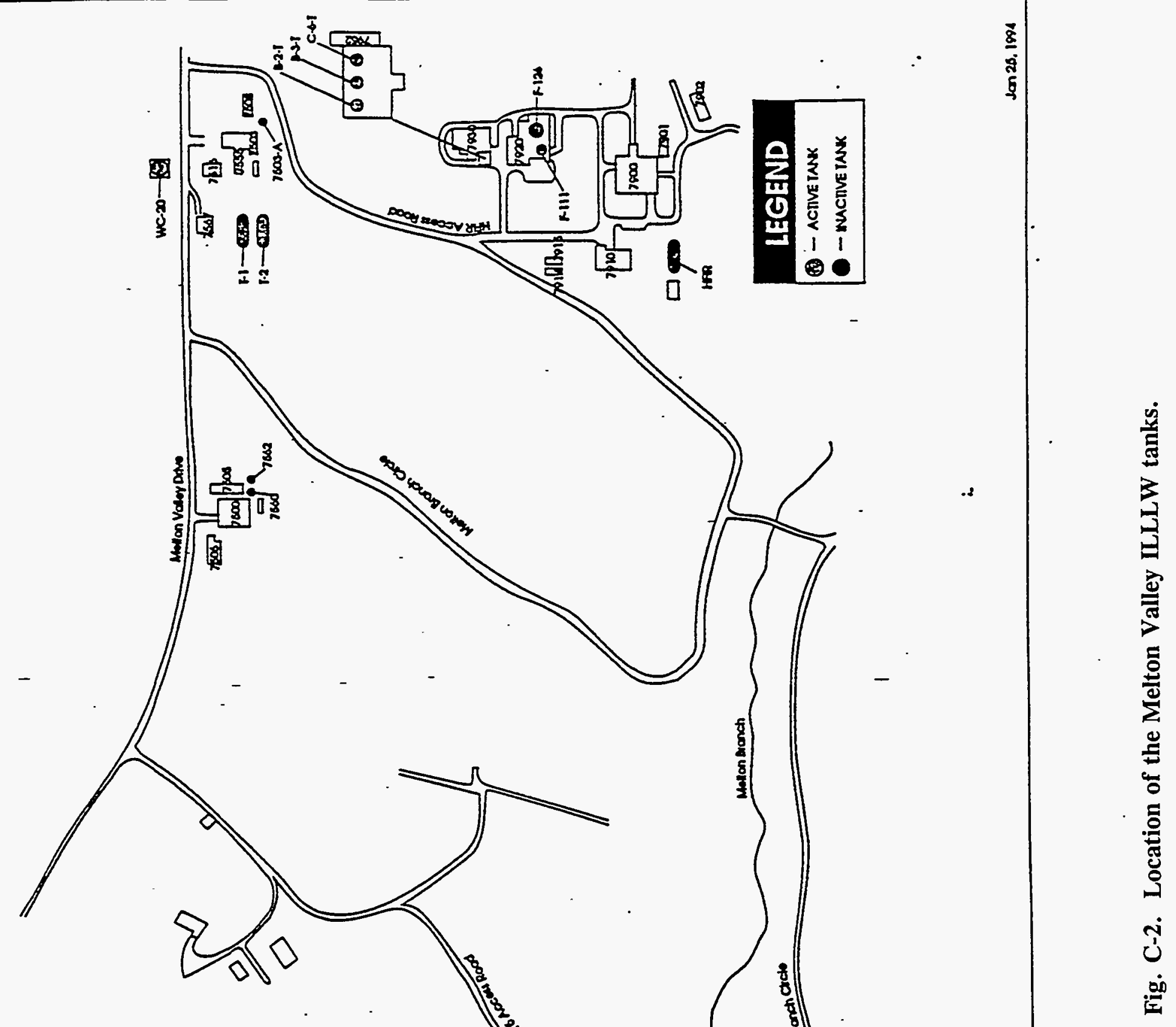




\section{C.2. TANK LEVEL TREND ANALYSIS}

The following section contains tank data, information regarding level trends, and factors affecting them.

\section{C.2.1 GUNITE STORAGE TANK W-5; SOUTH TANK FARM SITE, 3507, NORTH ROW}

Tank W-5 level has been increasing slowly; this is attributed to inleakage, probably due to rainfall. At the end of FY 1994 the tank was only about $16 \%$ full. The level instrument is a Robertshaw Inven-Tel-185 conductivity probe. There were apparently no reported instrumentation problems.

\section{C.2.2 GUNITE STORAGE TANK W-6; SOUTH TANK FARM SITE, 3507, SOUTH ROW}

Tank W-6 level has been increasing at a greater rate than the other tanks; this is attributed to inleakage, probably due to rainfall. At the end of FY 1994 the tank was about $81 \%$ full. The level instrument is a Robertshaw Inven-Tel-185 conductivity probe. There was a brief instrument failure in December 1993, but it was quickly repaired and there was no real change in level during the measurement outage.

\section{C.2.3 GUNITE STORAGE TANK W-7; SOUTH TANK FARM SITE, 3507, SOUTH ROW}

Tank W-7 level has increased slightly over several years; at the end of FY 1994 it was only about three percent full. The level instrument is a Robertshaw Inven-Tel-185 conductivity probe. There was a brief problem with the instrument system in August 1994, but there were quick repairs and no real level changes occurred during the instrument outage.

\section{C.2.4 GUNITE STORAGE TANK W-8; SOUTH TANK FARM SITE, 3507, SOUTH ROW}

Tank W-8 level has been increasing slowly; this is attributed to inleakage, probably due to rainfall. At the end of FY 1994 the tank was about 35\% full. The level instrument is a Robertshaw Inven-Tel-185 conductivity probe. No instrument problems were reported during FY 1994. 
C -10

\section{C.2.5 GUNITE STORAGE TANK W-9; SOUTH TANK FARM SITE, 3507, NORTH ROW}

Tank W-9 level has been increasing slowly; this is attributed to inleakage, probably due to rainfall. At the end of FY 1994 the tank was about $26 \%$ full. The level instrument is a Robertshaw Inven-Tel-185 conductivity probe. No instrument problems were reported during FY 1994.

\section{C.2.6 GUNITE STORAGE TANK W-10; SOUTH TANK FARM SITE, 3507, SOUTH ROW}

Tank W-10 level has been increasing slowly; this is attributed to inleakage, probably due to rainfall. At the end of FY 1994 the tank was about $61 \%$ full. The level instrument is a Robertshaw Inven-Tel-185 conductivity probe. No instrument problems were reported during FY 1994.

\section{C.2.7 TANK W-11; SOUTH EAST OF SOUTH TANK FARM}

Tank W-11, at the end of FY 1994, is approximately $53 \%$ full of liquid with a small amount of sludge. The inleakage appears to be from rain water. Approximately $2670 \mathrm{gal}$ were removed from the tank during FY 1994. The tank has a staff gauge for level measurement. The T-bar broke in May 1994, but was repaired with no real change in level occurring during the instrument outage.

\section{C.2.8 OLD HYDROFRACTURE TANK T-1; OLD HYDROFRACTURE FACILITY, 7852, MELTON VALLEY}

At the end of FY 1994, tank T-1 is about $58 \%$ full of liquid and sludge. The tank structure is sound, therefore there is no rain water infiltration, nor are there concerns for loss of tank contents. Tank $\mathrm{T}-1$ has a Foxboro Model 13A DP transmitter for level measurement. Various instrument problems occurred throughout the year including instrument freezing, power outages and instrument air supply failures. None of the incidents had any real effect on the tank level.

\section{C.2.9 OLD HYDROFRACTURE TANK T-2; OLD HYDROFRACTURE FACILITY, 7852, MELTON VALLEY}

At the end of FY 1994, tank T-2 is about $70 \%$ full of liquid and sludge. The tank structure is sound, therefore there is no rain water infiltration, nor are there concerns for loss of tank contents. Tank T-2 has a Foxboro Model 13A DP transmitter for level measurement. Various instrument problems occurred throughout the year including instrument freezing, power outages and instrument air supply failures. None of the incidents had any real effect on the tank level. 


$$
\text { C }-11
$$

\section{C.2.10 OLD HYDROFRACTURE TANK T-3; OLD HYDROFRACTURE FACILITY, 7852, MELTON VALLEY}

At the end of FY 1994, tank T-3 is about $11 \%$ full of liquid and sludge. The tank structure is sound, therefore there is no rain water infiltration, nor are there concerns for loss of tank contents. Tank T-3 has a Foxboro Model 13A DP transmitter for level measurement. Various instrument problems occurred throughout the year including instrument freezing, power outages and instrument air supply failures. None of the incidents had any real effect on the tank level.

\section{C.2.11 OLD HYDROFRACTURE TANK T-4; OLD HYDROFRACTURE FACILITY, 7852, MELTON VALLEY}

At the end of FY 1994, tank T-4 is about $60 \%$ full of liquid and sludge. The tank structure is sound, therefore there is no rain water infiltration, nor are there concerns for loss of tank contents. Tank T-4 has a Foxboro Model 13A DP transmitter for level measurement. Various instrument problems occurred throughout the year including instrument freezing, power outages and instrument air supply failures. None of the incidents had any real effect on the tank level.

\section{C.2.12 OLD HYDROFRACTURE TANK T-9; OLD HYDROFRACTURE FACIITY, 7852, MELTON VALLEY}

At the end of FY 1994, tank T-9 is about $40 \%$ full of liquid and sludge. The tank structure is sound, therefore there is no rain water infiltration, nor are there concerns for loss of tank contents. Tank T-9 has a Foxboro Model 13A DP transmitter for level measurement. Various instrument problems occurred throughout the year including instrument freezing, power outages and instrument air supply failures. None of the incidents had any real effect on the tank level.

\section{C.2.13 THORIUM TANK TH-1; SOUTH OF BUILDING 3503}

Tank TH-1 is empty. A conductivity probe is inserted through an access pipe to check for liquid level. No permanent level instrumentation is mounted to the tank.

\section{C.2.14 THORIUM TANK TH-2; SOUTH OF BUILDING 3503}

Tank TH-2 is empty. A conductivity probe is inserted through an access pipe to check for liquid level. No permanent level instrumentation is mounted to the tank.

\section{C.2.15 THORIUM TANK TH-3; SOUTH OF BUILDING 3503}

Tank TH-3 is empty. A conductivity probe is inserted through an access pipe to check for liquid level. No permanent level instrumentation is mounted to the tank. 


$$
\text { C }-12
$$

\section{C.2.16 THORIUM TANK TH-4; SOUTH OF BUILDING 3500}

Tank TH-4 has been very full throughout FY 1994. None of the contents were drawn off during this year. The level instrument is a Robertshaw Inven-Tel-185 model conductivity probe. The instrumentation required frequent recalibration activities throughout the year. Only one power outage in November 1993 occurred, but did not effect the real level of the tank.

\section{C.2.17 TANK W-1; NORTH TANK FARM, NORTH OF CENTRAL AVENUE, SITE 3023}

At the end of FY 1994, tank W-1 is about $50 \%$ full. The level increase is mostly due to rain water accumulation. The level instrument is a Robertshaw Inven-Tel-185 model conductivity probe. In July 1994, there was a power outage and a brief problem with instrument failure in both October 1993 and July 1994. Repairs were made and there was no real effect on the tank level.

\section{C.2.18 TANK W-2; NORTH TANK FARM, NORTH OF CENTRAL AVENUE, SITE 3023}

Tank W-2, at the end of FY 1994, is approximately $40 \%$ full. The level instrument is a Robertshaw Inven-Tel-185 model conductivity probe. A power outage in August 1994 is the only incident that was reported against this system, but there was no real effect on the tank level.

\section{C.2.19 TANK W-3; NORTH TANK FARM, NORTH OF CENTRAL AVENUE, SITE 3023}

Tank W-3 is known to collect surface water. At the end of FY 1994, the tank is approximately $20 \%$ full. A total of 7600 gal were removed from the tank during FY 1994. Tank W-3 has a staff gauge to measure the level in the tank. No instrument-related problems were reported.

\section{C.2.20 TANK W-4; NORTH TANK FARM, NORTH OF CENTRAL AVENUE, SITE 3023}

Tank W-4 is known to collect water, possibly through inlet piping to the tank. At the end of FY 1994, the tank is over $60 \%$ full. Tank W-4 has a staff gauge to measure the level in the tank. No instrument problems were reported in FY 1994.

\section{C.2.21 TANK W-13; NORTH TANK FARM, NORTH OF CENTRAL AVENUE, SITE 3023}

Tank W-13 was checked in November 1993 and is empty. Tank W-13 has a staff gauge for level measurement. No instrument problems were reported in FY 1994. 


\section{C.2.22 TANK W-14; NORTH TANK FARM, NORTH OF CENTRAL AVENUE, SITE 3023}

Tank W-14 was checked in November 1993 and is empty. Tank W-14 has a staff gauge for level measurement. No instrument problems were reported in FY 1994.

\section{C.2.23 TANK W-15; NORTH TANK FARM, NORTH OF CENTRAL AVENUE, SITE 3023}

Tank W-15 was checked in November 1993 and is empty. Tank W-15 has a staff gauge for level measurement. No instrument problems were reported in FY 1994.

\section{C.2.24 TANK W-1A; NORTH TANK FARM, NORTH OF CENTRAL AVENUE, SITE 3023}

Many rain events affected levels in tank W-1A throughout FY 1994. At the end of FY 1994, the tank is approximately $25 \%$ full. Throughout the year a total of 31,125 gal were emptied to the active LLLW system. Figure C-3 is a sample of a more active tank level trending analysis. Tank W-1A is monitored with a Foxboro 823 pneumatic gauge. No instrument problems were reported this year.

\section{C.2.25 TANK WC-1; BETWEEN BLDG. 3038 AND 3037, NORTH OF CENTRAL AVENUE}

Tank WC-1 was checked again in May 1994 and is empty. A conductivity probe is inserted through an access pipe to check for liquid level. No permanent level instrumentation is mounted to the tank.

\section{C.2.26 TANK WC-15; SOUTH OF BUILDING 3587, CORNER OF WHITE OAK AVE. AND FIFTH ST.}

Ground water infiltrates tank WC-15 causing the tank level to rise and fall as the level of the ground water table rises and falls. Apparent "spikes" in the levels throughout the year coincide with rain fall events. A Robertshaw Inven-Tel-185 model conductivity probe measures the level for WC-15. There was a brief instrument failure in May 1994, but it was repaired and did not effect the real tank level. A power outage in November 1993 also had no real effect on the tank level.

\section{C.2.27 TANK WC-17; SOUTH OF BUILDING 3587, CORNER OF WHITE OAK AVE. AND FIFTH ST.}

Ground water infiltrates tank WC-17 through two holes in the bottom causing tank levels to rise and fall as the level of the ground water table rises and falls. Apparent "spikes" in the levels throughout the year coincide with rain fall events. A Foxboro 823 
C -14

\section{DATA OISCLAIMER}

The data presented herein is protininary and has nol been validated in eccordance with established regulatory protocols end procedures. Use of this data is restricled to non-regulatory purpo3es. By rolessing this dala, noither Musth Mariella Energy Systems, Ina, nor USDOE, their employees, or subcontractors, is making any representation whatsoever that if is true, accuato, or complete.

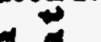

: : ..
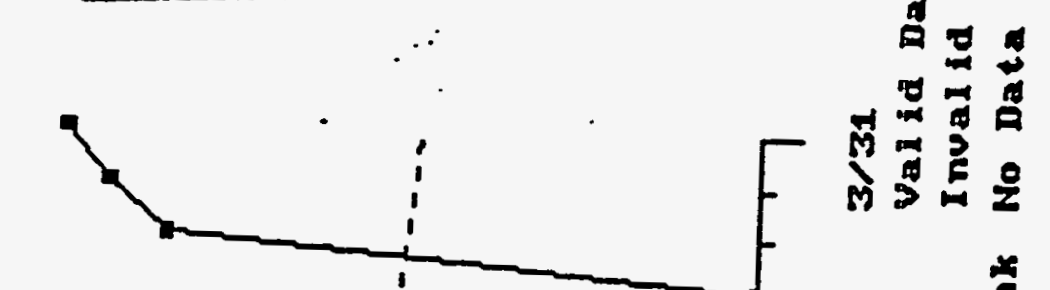

म 2

$\frac{1}{3}$

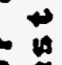

0

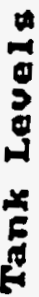

告

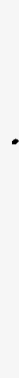
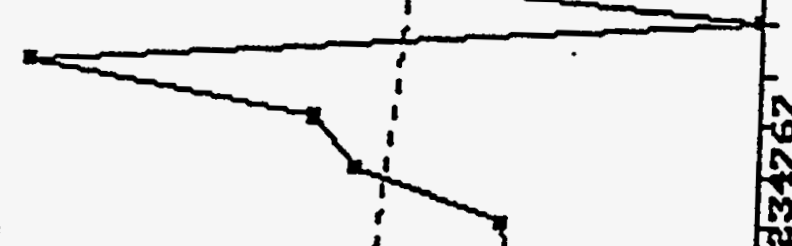

$-0 \frac{5}{0}$ 


$$
C-15
$$

pneumatic gauge measures the level for WC-17. There were no instrument-related problems reported this year.

\section{C.2.28 TANK 7560; EAST OF BULDING 7500, MELTON VALLEY}

Tank 7560 is empty. A conductivity probe is inserted through an access pipe to check for liquid level. No permanent level instrumentation is mounted to the tank.

\section{C.2.29 TANK 7562; EAST OF BULDING 7500, MELTON VALLEY}

Tank 7562 is receiving inleakage from an unknown source. During FY 1994, the tank overflowed causing a Category III Occurrence. The Occurrence was resolved by unearthing and uncovering the tank and pumping out 8800 gal of liquid. As long as the contents are periodically pumped to a transfer truck, there is little risk of another overflow incident. At the end of FY 1994, the tank is approximately $20 \%$ full. A pneumatic gauge measures the level in Tank 7562. No instrument-related problems were reported this year.

\section{C.2.30 TANK T-30; SOUTH OF BULDING 4507, UNDERGROUND IN CONCRETE PIT}

Tank T-30 was emptied just prior to the start of FY 1994. Previously accumulated data indicates the tank structure is sound and that the tank is expected to still be empty. Tank $\mathrm{T}-30$ and the associated sump have differential pressure instruments which have readouts at the control panel in Building 4507. The level status has been monitored daily by Waste Management personnel.

\section{C.2.31 TANK W-19; SOUTH OF SOUTH TANK FARM, NORTH OF BULDING 3517}

Tank W-19 was checked in May 1994; it is empty. Tank W-19 has no level measurement instrumentation.

\section{C.2.32 TANK W-20; SOUTH OF SOUTH TANKS FARM; NORTH OF BUILDING 3517}

Tank W-20 was checked in May 1994; it is empty. Tank W-20 has no level measurement instrumentation.

\section{C.2.33 TANK 3001-B; SOUTH OF BUILDING 3001}

Tank 3001-B, with only $1 / 2$ inch of liquid in it, is considered to be empty. Tank 3001$B$ has no level measurement instrumentation. 


$$
\text { C }-16
$$

\section{C.2.34 TANK 3003-A; SOUTH OF BUILDING 3003}

Tank 3003-A is empty. Tank 3003-A has no level measurement instrumentation.

\section{C.2.35 TANK 3004-B; EAST OF BULLDNG 3008; UNDERGROUND, UNDERNEATH LANDSCAPE ROCKS ON PUBLIC ACCESS WALK TO GRAPHITE REACTOR}

Tank 3004-B is empty. Tank 3004-B has no level measurement instrumentation.

\section{C.2.36 TANK 3013; EAST OF BULDING 3017, SOUTH OF BUILDING 3013}

Tank 3013 is empty. Tank 3013 has no level measurement instrumentation.

\section{C.2.37 TANK 7503-A; NORTHWEST OF BUILDING 7503, MELTON VALLEY}

Tank 7503-A contains only a thin layer of dry sludge. The tank is empty at this time. Tank 7503-A does not have working level instrumentation.

\section{C.2.38 TANK H-209; SOUTHWEST OF BULLDING 3517, NEXT TO WHITE OAK AVE.}

Tank H-209 is empty. The tank has no level measurement instrumentation.

\section{C.2.39 TANK 3002-A; SOUTH OF BUILDING 3002, NORTH OF BUILDING 3001}

Tank 3002-A is approximately half full. The tank still collects drainage from the Building 3002 Filter House, probably from rain water infiltration. The tank has no level measurement instrumentation.

\section{C.2.40 TANK 4501-P; UNDERNEATH BASEMENT FLOOR OF BUILDING 4501}

Tank 4501-P contains approximately two gal of liquid as residual from a 1990 emptying and rinse operation. A conductivity probe is inserted into the tank dip leg to detect the presence of liquid. In addition, there is a manometer type level indicator, which is a little more difficult to use.

\section{C.2.41 TANK S-424; NORTHWEST OF BUILDING 3517}

Tank S-424 is empty. S-424 has a pneumatic gauge and has a readout at Building 3517. No instrument-related problems were reported this year. 


\section{C.2.42 TANK T-14; NEW HYDROFRACTURE FACILITY (MELTON VALLEY)}

Tank T-14 has some residual, sludge-like grout mixture in the tank. Tank T-14 has a pneumatic liquid-level gauge. No instrument-related problems were reported this year.

\section{C.2.43 TANK W-17; SOUTH TANK FARM}

Tank W-17 collects inleakage which is routinely emptied and processed at the LLLW evaporator. An inlet line to W-17 is thought to be the source of the inleakage. Tank W-17 collected a total of 792 gal by the end of FY 1994. W-17 is equipped with a pneumatic level detector with a continuous readout at the WOCC. No instrument-related problems were reported this year.

\section{C.2.44 TANK W-18; SOUTH TANK FARM}

Tank W-18 collects inleakage which is routinely emptied and processed at the LLLW evaporator. An inlet line to W-18 is thought to be the source of the inleakage. Tank W-18 had 518 gal at the end of FY 1994. A total of 5075 gal were removed during FY 1994. W-18 is equipped with a pneumatic level detector with a continuous readout at the WOCC. No instrument-related problems were reported this year.

\section{C.2.45 TANK W-1-I; UNDER BUILDING 3028}

Tank W-1-I is empty of liquid but probably contains residual solids. The tank has a pneumatic level gauge with a readout at Building 3028 which indicates that the tank is still empty. No instrument-related problems were reported this year.

\section{C.2.46 TANK WC-4; ADJACENT TO BULLING 3026C, ON WEST SDE}

Tank WC-4 has accumulated approximately 275 gal of liquid at the end of FY 1994. While there is a leaking flange on the tank, it is suspected the primary reason for the increase in liquid volume is an approximately $0.25 \mathrm{gal} /$ day increase from moisture acquired from the tank ventilation. Tank WC-4 has a pneumatic level detector with a continuous readout at the WOCC. No instrument-related problems were reported in FY 1994.

\section{C.2.47 WC-5; SOUTH OF BULLDNG 3503}

Tank WC-5 contained 476 gal of liquid at the end of FY 1994. The primary source of inleakage appears to be rain water. Tank WC-5 has a pneumatic level detector with a continuous readout at the WOCC. No instrument-related problems were reported in FY 1994. 
C -18

\section{C.2.48 TANK WC-6; SOUTH OF BULLDING 3503}

Tank WC-6 contained approximately 217 gal of liquid at the end of FY 1994. The primary source of the inleakage appears to be rain water. Tank WC-6 has a pneumatic level detector with a continuous readout at the WOCC. No instrument-related problems were reported in FY 1994.

\section{C.2.49 TANK WC-8; SOUTH OF BUILDING 3503}

Tank WC-8 contained approximately 425 gal at the end of FY 1994. The tank is used to collect pump priming water for a near-by pump. Tank WC-8 has a pneumatic level detector with a continuous readout at the WOCC. No instrument-related problems were reported in FY 1994.

\section{C.2.50 TANK WC-11; SOUTH OF BUILDING 3587}

Tank WC-11 contained approximately 1576 gal at the end of FY 1994, some of which is sludge. The tank collects water from the Building 4556 filter pit discharge for Building 4507. Cell ventilation duct work also discharges into Tank WC-11. Tank WC-11 has a pneumatic level detector with a continuous readout at the WOCC. No instrument-related problems were reported in FY 1994.

\section{C.2.51 TANK WC-12; SOUTH OF BUILDING 3587}

Tank WC-12 contained approximately 389 gal of liquid at the end of FY 1994. A total of 185 gal were removed from the tank in FY 1994. The tank collects Tank T-30 sump water. Tank WC-12 has a pneumatic level detector with a continuous readout at the WOCC. No instrument-related problems were reported in FY 1994.

\section{C.2.52 TANK WC-13; SOUTH OF BULLDNG 3587}

Tank WC-13 contained approximately $288 \mathrm{gal}$ at the end of FY 1994. The tank collects water from floor drains in Building 4501 . Tank WC-13 has a pneumatic level detector with a continuous readout at the WOCC. No instrument-related problems were reported in FY 1994.

\section{C.2.53 TANK WC-14; SOUTH OF BUILDING 3587}

Tank WC-12 contained approximately 650 gal of liquid at the end of FY 1994. Tank WC-14 has a pneumatic level detector with a continuous readout at the WOCC. No instrument-related problems were reported in FY 1994. 


\section{C -19}

\section{C.2.54 TANK W-12; SOUTH OF BULDING 3525}

Tank W-12 contained approximately 200 gal of liquid at the end of FY 1994. A total of 2181 gal were removed from the tank during this year. The source of inleakage to this tank is still being determined. Tank W-12 has a pneumatic level detector with a continuous readout at the WOCC. No instrument-related problems were reported in FY 1994.

Table C.2 summarizes the incidents affecting the 54 inactive LLLW tanks during FY 1994. 
Table C.2. Summary of inac

\begin{tabular}{|c|c|c|c|c|c|c|c|}
\hline Tent & Octooper, 1 lews & Monention, 140 & Decomber, 1893 & denemer, $1 \mathrm{men}$ & Februmy, 1994 & Merch, 19ex & Aporth \\
\hline$w \in$ & Nonetrity & No Aetraty & Instrumemt tamere, no res eftect on wert & Nonetry & Nonctiny & Nonatrity & NoN \\
\hline$w .7$ & No Aethity & Nonctivity & No Actutity & Nonotrity & Ho Retivity & Nonatimy & Nonec \\
\hline$w-8$ & No Aetritiy & $\begin{array}{l}\text { instrument monaty, no row } \\
\text { oftect on lowel }\end{array}$ & No Acturity & Nonatray & Nonethity & No Netwing & AOAN \\
\hline$w-11$ & No Natraty & Nonetry & 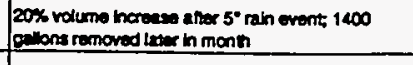 & No Notiviny & Nonethity & 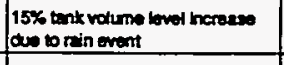 & 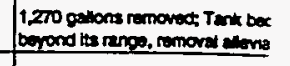 \\
\hline T.1 & No Actitity & Noxetwing & No Activity & 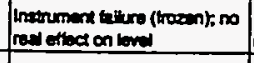 & 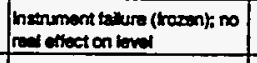 & Nonetrity & None \\
\hline$T-2$ & No Netwity & Nonctivity & Nonetrity & 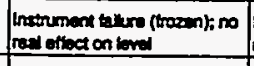 & 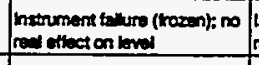 & 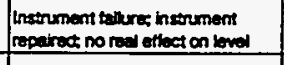 & None \\
\hline T.3 & No Activity & Monathity & No Netury & 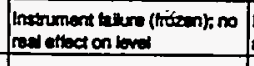 & 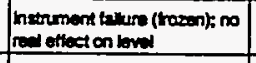 & Nonetrity & №ㅅN른 \\
\hline IA & No Activiy & MOACOVIYY & No NetVIY & 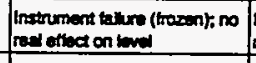 & $\begin{array}{l}\text { Instrument talure (hroson); no } \\
\text { red ethect on loved }\end{array}$ & No Aetrity & Nona \\
\hline To & No nestity & No Actity & No Aetvity & 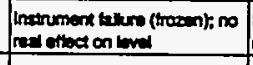 & 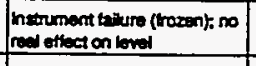 & No Actitly & Nonet: \\
\hline$I+1$ & No Notitity & 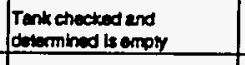 & Ao Activily & No Retiviy & Ho Actinty & No Netring & Nonet \\
\hline Ithe & No Actitiy & $\begin{array}{l}\text { Tenx checteod and } \\
\text { dotermined ts onnoy }\end{array}$ & No Actinty & Nonetrity & No Netwity & NoActivity & Nonet \\
\hline$\pi+3$ & Ho Netrity & Tenk chected and & No Activity & Nonetwy & Nonethaty & Nopetrity & Noness \\
\hline Ithe & Tank tue & 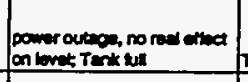 & Trantul & Tank hall & Tenk bur & 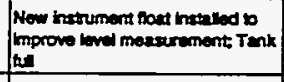 & 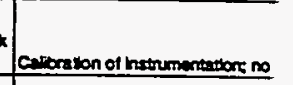 \\
\hline w-1 & insument problom ropereces no & No Netrity & 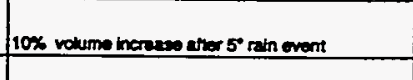 & Honatrey & 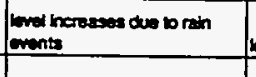 & brod haraeses da b rain mems & Nonetr \\
\hline H-2 & No Aetinty & Nonetrity & Nonetuty & Ho nethity & Nonetrity & Nonctivity & Nonert \\
\hline W-3 & Mo Aetrity & Nonativey & Tenk doses to tul & Tentival & Tank wul & Tenk hut & Tank kul \\
\hline$w+13$ & No Activty & 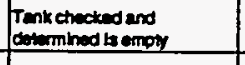 & No Actury & No Actrity & Nonetrity & Nonetrity & No Actror \\
\hline$w+14$ & No Retwity & 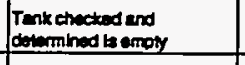 & No Netwity & No Notviny & Nonativity & Nonetorty & Noner \\
\hline$w \cdot 15$ & Noxaty & 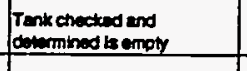 & Nonetivity & Nonetrity & No rectivi & No Nethity & No Aatron \\
\hline$w \cdot 1 A$ & No Actinty & 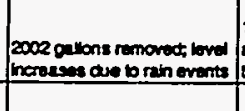 & 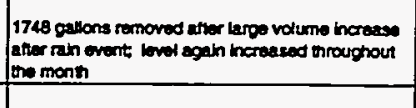 & 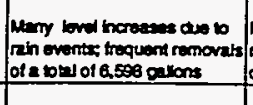 & 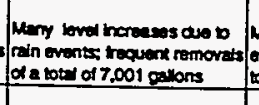 & 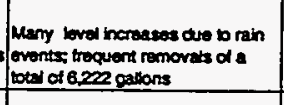 & 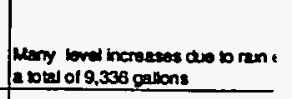 \\
\hline we-1 & No Aetwity & Nonetrity & No Acototy & Nonatity & No Activity & No Aetrity & Nonem \\
\hline ma.15 & 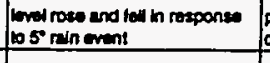 & 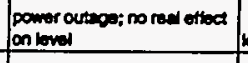 & 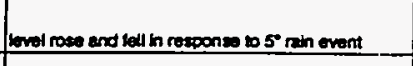 & Nonetriny & 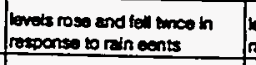 & 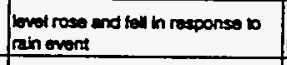 & loved rosos and tell h responsoo or \\
\hline wa-17 & 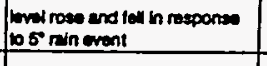 & Ao Actuty & 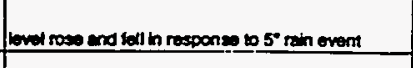 & Nonetray & 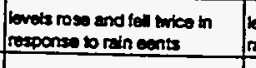 & 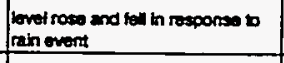 & 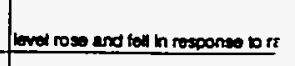 \\
\hline 7352 & No Actitity & No Actrity & No actity & No hativity & No activity & No Aemry & No Aetr \\
\hline w.19 & No Actutity & Boratraty & No Actinty & No reotidy & No Netiny & No Nething & No Aetr \\
\hline$w+20$ & No Nabity & No Actritity & No Activity & Nonatriy & No Activity & NoActivity & No nav \\
\hline W.18 & No Acotiny & No Actrtity & Ho Actritir & No Aeoviry & No retivity & No Activity & No Acer \\
\hline wed & No Aottity & No Actury & No Activity & Nonetraty & No Activity & No AEDiny & Nonatr. \\
\hline we-11 & No Acturty & No Actrity & No Actiny & No Aotivity & $\begin{array}{l}25 \% \text { tank volume increase in } \\
\text { rosponse to rain events }\end{array}$ & No Netivaty & Nonetri \\
\hline$w_{12}$ & No Acturity & Ho Netritity & No Actiny & No Netriry & No Actity & No ACovity & No haver \\
\hline W.12 & Nonctinity & No Aecthity & & & & NoActivity & Ist8 gamons removed \\
\hline
\end{tabular}


liquid low-level waste (ILLLW) tanks.

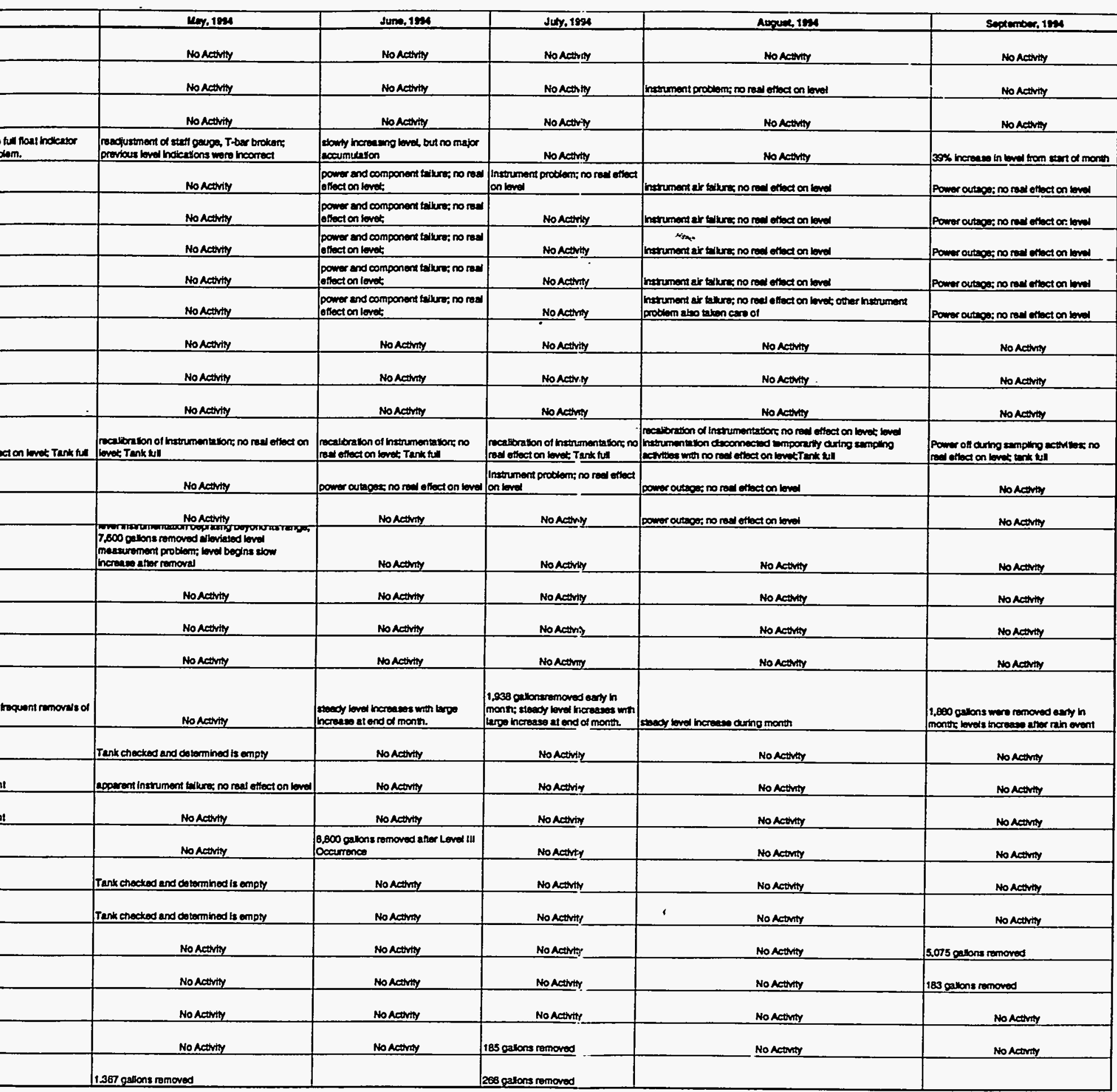




\section{DISTRIBUTION}

1. H. L. Boston

2. J. H. Hooyman

3. A. J. Kuhaida, Jr.

4-5. P. T. Owen

6. P. A. Schrandt

7. H. D. Wooten

8. P. S. Wood

9. ORNL Patent Section

10. Central Research Library

11-13. ORNL ER Doc. Mgmt. Center

14-16. Central ER Doc. Mgmt. Center

17. Laboratory Records Department

18. Office of Assistant Manager for Energy Research and Development, DOE Oak Ridge Operations Office, P.O. Box 2001, Oak Ridge, TN 37831-8600

19-20. Office of Scientific and Technical Information, P.O. Box 62, Oak Ridge, TN 37831 